UNIVERSIDADE DE SÃO PAULO

FACULDADE DE FILOSOFIA, LETRAS E CIÊNCIAS HUMANAS DEPARTAMENTO DE GEOGRAFIA

PROGRAMA DE PÓS-GRADUAÇÃO EM GEOGRAFIA FÍSICA

\title{
Educação a Distância na formação continuada de professores: o curso Áreas Verdes no Município de Alfenas - MG
}


ANA BEATRIZ SIQUEIRA TROIANO

\section{Educação a Distância na formação continuada de professores: o curso Áreas Verdes no Município de Alfenas - MG}

Dissertação de Mestrado apresentada a Faculdade de Filosofia, Letras e Ciências Humanas da Universidade de São Paulo.

Área de Concentração: Geografia Física 
Nome: TROIANO, Ana Beatriz Siqueira

Título: Educação a Distância na formação continuada de professores: o curso áreas verdes no município de Alfenas - MG

Dissertação apresentada à banca examinadora do Programa de Pós Graduação em Geografia Física da Faculdade de Filosofia, Letras e Ciências Humanas da Universidade de São Paulo para obtenção do título de Mestre em Ciências na área de concentração em Geografia Física.

Trabalho aprovado pela banca examinadora em:

Profa. Dra. Magda Adelaide Lombardo (orientadora)

Instituição: USP

Julgamento:

Assinatura:

Prof. Dr.

Instituição:

Julgamento:

Assinatura:

Prof. Dr.

Instituição:

Julgamento: Assinatura: 
Dedico à Professora Dra. Magda Adelaide Lombardo, aos meus pais, Milton e Raquel, à minha irmã Valéria, ao Rafael e à minha amiga Larissa. 


\section{AGRADECIMENTOS}

Ao meu pai Milton e à minha mãe Raquel, por sempre terem me incentivado com amor, carinho e respeito em toda e qualquer situação.

À minha irmã Valéria, por ser um exemplo de pessoa que respeito e admiro muito.

Ao Rafael, que com muito amor, carinho e paciência esteve comigo em todos os momentos, mesmo naqueles em que eu estava ausente.

À Professora Magda, pela oportunidade, pelos valiosos ensinamentos ministrados e pela firme orientação imprimida não apenas durante a elaboração deste trabalho, mas sobretudo em minha vida, doações estas que contribuíram enormemente para meu crescimento intelectual e pessoal.

À amiga Larissa, por toda dedicação, amizade, contribuições e disposição em me ajudar sempre. À amiga Amanda pelas contribuições necessárias para a realização deste trabalho.

À equipe do CEAPLA, que sempre me ajudou, dando apoio técnico e pelas grandes amizades criadas no departamento.

À equipe do CECEMCA e aos professores que realizaram o curso “Áreas Verdes” em Alfenas - MG, por terem contribuído com todas as informações necessárias para a realização desta pesquisa.

Aos amigos Teresa e Wilson, sempre solidários e presentes, tornando esse momento da vida especial.

Ao Felix, pelas valiosas contribuições em inglês.

À amiga Cristina, que apesar de distante contribui sempre para a realização dos meus projetos. 
"O segredo de uma vida empolgante não está em descobrir maravilhas, mas sim em procurálas."

Augusto Ruschi 
TROIANO, A. B. S. Educação a Distância na formação continuada de professores: o curso áreas verdes no município de Alfenas - MG. Dissertação (Mestrado) - Faculdade de Filosofia, Letras e Ciências Humanas, Universidade de São Paulo, São Paulo, 2009.

\section{RESUMO}

Este trabalho teve como objetivo desenvolver a formação continuada com ênfase na área ambiental por meio da Educação a Distância. Com o propósito de desenvolver uma Formação Continuada para Professores, o Ministério da Educação criou a Rede Nacional de Formação Continuada de Professores de Educação Básica, um programa que indicou universidades brasileiras para promover a formação de professores. Neste contexto foi criado o CECEMCA - Centro de Educação Continuada em Educação Matemática, Científica e Ambiental, que responde por ações dirigidas à formação continuada de professores. $\mathrm{O}$ objetivo do programa é melhorar a qualidade de ensino através da capacitação e aprimoramento dos conhecimentos dos professores das escolas municipais. Dentre os produtos desenvolvidos pelo CECEMCA, destaca-se nessa pesquisa o Caderno "Áreas Verdes", que apresenta textos de apoio a atividades de formação continuada de professores de Ensino Fundamental ( $1^{\circ}$ a $4^{\circ}$ ano) com tema Áreas Verdes e Educação Ambiental. Por abordar a temática ambiental, o Caderno "Áreas Verdes" constitui uma forma abrangente de educação que pode alcançar os cidadãos por meio de um processo participativo que promove nas pessoas uma consciência crítica sobre a problemática ambiental. Como parte do programa de formação continuada de professores, o CECEMCA criou e realizou um curso no município de Alfenas - MG. O curso foi apresentado em dois módulos, presencial e a distância. O trabalho de campo no curso presencial apresenta-se como uma metodologia indispensável na compreensão da realidade local e também, através da solidariedade do grupo, desenvolve um dinamismo na relação do ensino-aprendizagem e na compreensão dos conceitos sobre área verde e meio ambiente. No curso a distância, a plataforma virtual Teleduc constituiu-se em um instrumento adequado no desenvolvimento do curso. Os registros e os questionários confirmam que os dois módulos do curso foram satisfatórios e acrescentaram novos conceitos relacionados ao meio ambiente.

Palavras-chave: Educação a Distância - Alfenas - Educação Continuada - Áreas Verdes Educação Ambiental 
TROIANO, A. B. S. The role of Long Distance Learning in the Continuing Education of Teacher: The course "Green Areas" in the city of Alfenas - MG. Dissertação (Mestrado) Faculdade de Filosofia, Letras e Ciências Humanas, Universidade de São Paulo, São Paulo, 2009.

\section{ABSTRACT}

The objective of this paper is the development of the Continuing Educations Programme, focused in the environmental area through the means of the Long Distance Learning. With the purpose to create Continuing Education for Teachers, the Ministry of education has created the National Network of Continuing Education for Teachers - primary school, a program that had designated certain Brazilians universities to promote teacher training. In this context CECEMCA (Centre of Continuing Education, in Mathematics, Science and Environmental) was created to deal with actions related to Continuing Education for Teachers. The objective of this program is to update the quality of education through training and improving the knowledge of teachers in municipal schools. Among the products developed by CECEMCA is the book "Green Areas", discussed centrally in this study, which presents texts that support continuing education activities for teachers in primary schools, on the topics of "Green Areas" and Environmental Education. By employing the environmental theme, the book "Green Areas" is a comprehensive educational material that can reach all citizens through a participatory framework that provides individuals with a critical lens for analysing environmental problems. As part of the Continuing Education Program for teachers, CECEMCA created and ran a course in Alfenas - MG. The course was designed in two modules: Classroom Learning and Long Distance Learning. The fieldwork undertaken on the Classroom Learning module was designed to provide essential methodology for understanding local realities and also, through the solidarity of the group, develop dynamism in the relationship between teaching and learning, and understanding the concepts of "Green Areas" and environment. During long distance learning, the virtual platform Teleduc was formed as an appropriate instrument in the development of the course. The records and questionnaires confirm that the two modules of the course were satisfactory and created new concepts related to the environment.

Key-words: Long Distance Learning - Alfenas - Continuing Education - Green Areas Environmental Education 
ÍNDICE

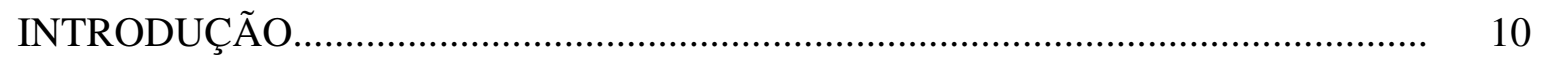

JUSTIFICATIVA............................................................................. 13

OBJETIVOS ........................................................................................ 17

CAPÍTULO 1 - CONSIDERAÇÕES INICIAIS SOBRE A FORMAÇÃO DE PROFESSORES

1.1 -A FORMAÇÃO CONTINUADA DE PROFESSORES ATRAVÉS DA EDUCAÇÃO AMBIENTAL - EA.

1.2 - A FORMAÇ̃̃O CONTINUADA DE PROFESSORES ATRAVÉS DA EDUCAÇÃO A DISTÂNCIA EaD..

CAPÍTULO 2 - EDUCAÇÃO A DISTÂNCIA (EaD) ENQUANTO MODALIDADE EDUCATIVA.

2.1 ASPECTOS HISTÓRICOS SOBRE EDUCAÇÃO A DISTÂNCIA..........

2.1.1 - BREVE HISTORICO DA EaD NO BRASIL.................................. 35

2.2 - ENSINO ATRAVÉS DA REDE MUNDIAL DE COMPUTADORES INTERNET.

2.3 - CONCEITUALIZAÇÃO SOBRE QUALIDADE EM EaD....................... 38

CAPÍTULO 3 - CENTRO DE EDUCAÇÃO CONTINUADA EM EDUCAÇÃO MATEMÁTICA, CIENTPIFICA E AMBIENTAL - CECEMCA.

3.1 - CECEMCA - ESTRUTURA E ORGANIZAÇÃO........................................ 45

3.2 - PRODUTOS CECEMCA - NUCLEO RIO CLARO................................. 47 CAPÍTULO 4 - "ÁREAS VERDES": UMA PROPOSTA A SER DESENVOLVIDA JUNTO A PROFESSORES DA REDE PUBLICA DE

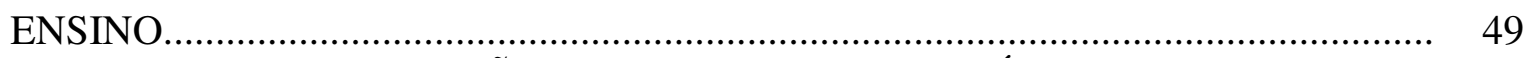

4.1 - CONSIDERAÇÕES SOBRE O CADERNO “ÁREAS VERDES”.......... 49

4.2 - CARACTERIZAÇÃO E IMPORTÂNCIA DAS ÁREAS VERDES....... 50

4.3 - BENEFÍCIOS DA ARBORIZAÇÃO URBANA....................................... 51

CAPÍTULO 5 - APLICAÇÃO DO CURSO ÁREAS VERDES NO MUNICÍPIO DE ALFENAS.

5.1 - A REALIDADE LOCAL ………………………………………….... 55

5.2 - O CURSO ÁREAS VERDES................................................................ 57

5.3 - O CURSO PRESENCIAL.................................................................... 58

5.4 - O CURSO A DISTÂNCIA.................................................................... 65

CAPÍTULO 6 - DISCUSSÃO DOS RESULTADOS.................................................... 72

6.1 - ANÁLISE DA OPINIÃO DOS PROFESSORES-COORDENADORES .. 80 CONSIDERAÇÕES FINAIS.......................................................................... 84

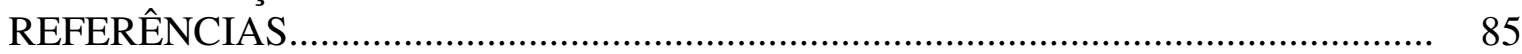

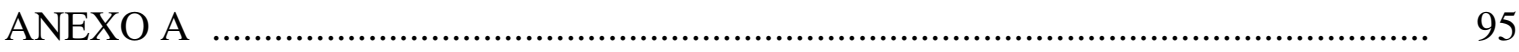




\section{INTRODUÇÃO}

A formação de professores deve coincidir com uma ação contínua centrada na atividade cotidiana da sala de aula próxima dos problemas reais dos professores, tendo como referência central o trabalho de equipes docentes, assumindo, portanto, uma dimensão participativa, flexível e ativa/investigadora.

Nesse trabalho, conforme a concepção de Garcia (1995) entendemos a formação de professores como um continuum, ou seja, uma formação onde se destaca o valor da prática como elemento de análise e reflexão do professor.

Sendo assim, falar de formação de professores é falar de um investimento educativo dos projetos da escola, pois uma mudança educacional depende dos professores e da sua formação, dependendo também, da transformação das práticas pedagógicas na sala de aula (NÓVOA, 1995).

Nesse sentido, a formação do professor se traduz em um dos elementos centrais do processo educativo, cuja problemática tem resultado em expressivos debates no meio educacional. Por esta razão, diversos programas e propostas de formação sob diferentes linhas e abordagens teóricas, têm sido direcionados aos professores que atuam nos sistemas de ensino. Tais programas e propostas em muitos casos chegam aos professores como resultado de convênios estabelecidos entre as Redes Estaduais e Municipais de Ensino e Universidades Públicas ou Privadas, Fundações, Institutos e outros. Além disso, é possível observar a recorrência da adoção de modelos de formação, pautados na Educação a Distância.

Em cada sociedade, a educação deve ser planejada para atender, simultaneamente, ao interesse social e ao interesse dos indivíduos. É da associação desses interesses que surgem os seus princípios essenciais e são estes que devem direcionar a produção dos conteúdos do ensino, as práticas pedagógicas e a relação da escola com a comunidade e com o mundo (SANTOS, 2000).

A educação pode ser um mecanismo de transformação para melhorar a posição dos países em desenvolvimento no mercado mundial. Para isso, é necessário que se siga um critério propício nos programas de educação tecnológica.

Deve-se ter consciência sobre o verdadeiro papel da tecnologia, no sentido de atender as necessidades de todos com uma educação mais humanista e abrangente que desenvolva conhecimentos tecnológicos adequados à realidade de seres humanos e não apenas do mercado. 
A utilização da tecnologia no processo ensino/aprendizagem tem mudado a educação nos últimos tempos. Atualmente, professores e alunos estão interagindo, não apenas em aulas presenciais, mas também em cursos a distância, via Internet. Os alunos estão participando de aulas em suas residências; os professores estão armazenando materiais didáticos para disponibilizar aos seus alunos; as Instituições de Ensino estão utilizando tecnologias de áudio e vídeo, via Internet, para ajudar os professores a maximizar suas habilidades, a fim de melhorar a aprendizagem de seus alunos. Com isto, pode-se dizer que está ocorrendo uma revolução na Educação, uma nova era no processo ensino/aprendizagem. (MAGALHÃES, 2004).

A Internet pode proporcionar para os educadores uma nova e excitante oportunidade para ensinar e aprender (GOTTSCHALK, 2002). Além disso, a Internet tornou-se o processo de aprendizagem mais maleável em relação ao tempo e ao local, facilitando o acesso à educação (LEVY, 2003).

Assim, a Educação a Distância via internet, cuja sigla também é EaD, foi inserida em algumas situações no mesmo patamar do ensino presencial. Para o conceito fundamental de $\mathrm{EaD}$ adotado no presente trabalho, o estudante e o professor encontram-se separados fisicamente e, na maioria das vezes, também temporalmente (MOORE; KEARSLEY, 1996).

O surgimento da Internet contribuiu no sentido de criar possibilidades antes não imaginadas para a questão da educação, como por exemplo, a formação de comunidades virtuais de aprendizagem colaborativa Como descrito nesse trabalho, a EaD já é considerada, inclusive no Brasil, um meio oficial de ensino.

Para Rosenberg (2002), a Internet é uma tecnologia que, por unificar, permite que o aprendizado ultrapasse as fronteiras geográficas e organizacionais, e, assim, transforme o aprendizado, levando todos os envolvidos a avaliar novamente a sua função e seu objetivo.

Com o objetivo de estruturar um centro de formação continuada de professores da rede pública de ensino, através da modalidade de Ensino Presencial, semi-presencial e EaD, a UNESP através de um convenio com o MEC criou o Centro de Educação Continuada em Educação Matemática, Científica e Ambiental - CECEMCA. O CECEMCA - trabalha com várias ações nos municípios brasileiros, sendo que o presente trabalho aborda a ação no município de Alfenas - MG.

Através de um trabalho semi-presencial o Caderno "Áreas Verdes" foi utilizado na formação continuada dos professores da rede municipal de ensino no município de Alfenas.

A temática abordada no caderno (Áreas Verdes) é importante por exercer benefícios na qualidade de vida urbana. 
Para que o ser humano rompa com o processo de afastamento que leva à sua exclusão das esferas de decisões que dizem respeito ao seu ambiente e à sua qualidade de vida, e que o obriga a ajustar-se a estas decisões, a Educação Ambiental tem o papel de ensinar a pensar certo, de despertar uma atitude crítica, de promover a reflexão de mãos dadas com a ação (práxis), e de promover o encorajamento para que o ser humano volte a integrar-se, superando o simples ajustamento ou acomodação, e a assumir a luta pela recuperação e conservação de seu ambiente, que está intimamente ligada à garantia de sua dignidade como pessoa (TÓROTONISSI, 2005). 


\section{JUSTIFICATIVA}

A formação continuada de professores é uma questão bastante discutida e pesquisada atualmente, principalmente no que se refere à construção do conhecimento docente e à atualização deste conhecimento. Neste sentido, autores como Alves (1998), Marques (2003), Nóvoa (1992) e Tardif (2002), defendem a idéia de que a formação do professor ocorre em múltiplas esferas e é constituída por vários saberes. Levar em consideração estes princípios, na concepção destes autores, implica reconhecer que não existe um momento estanque de formação, mas sim, que ela vai sendo construída e reconstruída durante toda a trajetória profissional e também pessoal do professor.

Para Leite (2008), o conceito de Educação Continuada é amplo, vai além da aquisição de conhecimentos, participação em eventos e cursos pontuais, envolvendo a mudança de comportamento e de atitude, adquirindo posturas antes não cobradas pela sociedade.

Neder (2005) aponta a Educação a Distância (EaD) como "uma possibilidade de (re)significação paradigmática no contexto do processo de formação de professores", pois esta modalidade favorece a interação entre os sujeitos, propiciando o diálogo, a troca, a construção coletiva, na qual o professor assume um novo papel no processo de ensino-aprendizagem, não somente de transmissor de conhecimentos. Mais que isso, assume com os alunos uma posição de parceria. Desta forma, a autonomia do aluno é um dos ideais educativos, pois ele é estimulado e instigado a buscar, exigindo assim um grande comprometimento com a construção do conhecimento.

Estas questões que a autora nos remete acerca da construção de um novo paradigma, parecem estar diretamente ligadas ao modelo "Aprender a aprender, aprendendo", sustentado por Paulo Freire. A verdadeira construção do conhecimento se dá através de uma troca, de uma relação dialógica, ou seja, acontece através das relações com os outros e com o mundo (NEDER, 2005).

Para Guimarães (2004), um processo educativo de caráter participativo tem o papel de promover a auto-estima de educandos/educadores, bem como a confiança na potencialidade transformadora da ação pedagógica articulada, que transita das ciências naturais às ciências humanas e sociais, da filosofia à religião, da arte ao saber popular, em busca dos diferentes saberes.

A prática educativa deve partir dos problemas reais de cada comunidade, de modo que os educandos possam se identificar com o contexto estudado. Um grupo se interessa por uma questão ambiental quando entende suas relações, suas causas e efeitos, e quais as possibilidades de reversão da situação ambiental apresentada (TÓRO-TONISSI, 2005). 
Nesse sentido, a prática educativa deve buscar a formação do sujeito enquanto ser individual e social historicamente situado, ou seja, não se reduz a uma intervenção centrada somente no indivíduo - como se a mudança social se desse apenas pela soma das mudanças individuais - nem tampouco se dirige a coletivos abstratos diluindo a subjetividade num sistema social genérico e despersonalizado, cuja mudança acarretaria automaticamente na mudança das concepções e atitudes individuais (CARVALHO, 2004).

Trabalhar temas do dia-a-dia como base para a formação continuada de professores, pode ser um meio de envolve-los com a realidade da escola em que atuam, aproximando-os de seus alunos. Atualmente um tema muito presente no cotidiano dos cidadãos e da escola é o Meio Ambiente, os impactos gerados pelas ações diárias, pela falta de informação e planejamento. Sendo assim, a idéia de trabalhar a Educação Ambiental - EA com professores e uma forma de trabalhar com a atualidade e com a realidade do meio em que ele trabalha.

Segundo TÓRO-TONISSI, (2005) Educação Ambiental - EA constitui um valioso meio de despertar nos cidadãos, a partir de reflexões sobre a ética da relação ser humanoambiente, a compreensão da necessidade de se investir em um modelo de gestão ambiental integrada e participativa dos municípios, como um passo importante para a consolidação de um modelo mais sustentável e justo de sociedade. A autora acima citada defende que a EA pode ser um instrumento de transformação da sociedade, de busca da sustentabilidade real que garante o direito à vida com dignidade para todos os seres humanos e para todas as formas de vida.

Um projeto político pedagógico de uma Educação Ambiental que pretende ser transformadora tem uma especificidade: compreender as relações entre sociedade e natureza, para assim intervir sobre os problemas e conflitos ambientais, contribuindo para uma mudança de valores e atitudes, ou seja, para o desenvolvimento de indivíduos e grupos sociais capazes de identificar, problematizar e agir em relação às questões ambientais, tendo como horizonte uma ética preocupada com a justiça ambiental (CARVALHO, 2004).

De acordo com Oliveira (2002), a Educação Ambiental é um processo de construção de conhecimento que engloba o fazer educacional nas dimensões conceitual, procedimental e/ou atitudinal. Além dos conteúdos conceituais, portanto, através dos conteúdos procedimentais, busca-se o desenvolvimento de técnicas e instrumentos para promover a participação efetiva dos sujeitos envolvidos na ação educativa. Nos conteúdos atitudinais vale muito o testemunho de uma experiência vivida em busca de uma nova relação com o ambiente, do que apenas o falar sobre as questões ambientais. 
No momento em que o educador escuta as pessoas, descobre como e por onde iniciar o trabalho de Educação Ambiental com aquele público. Estimular o diálogo entre os participantes do processo de Educação Ambiental é colaborar para que aprendam a respeitar e estimar as concepções e opiniões dos outros, a refletir sobre e a defender sua própria opinião, enfim, a pensar democraticamente (TÓRO-TONISSI, 2005).

Dois importantes aspectos para que o resultado da prática em Educação Ambiental seja permanente são o seu caráter participativo e emancipatório. Um dos passos mais importantes e complexos em um trabalho de EA é promover na comunidade o desejo de participação, visto que em nosso país existe uma cultura que, através do assistencialismo, estimula o comodismo (TÓRO-TONISSI, 2005).

O indivíduo apenas sente-se motivado a participar quando se identifica com a questão ambiental, quando compreende a relação desta com sua vida, e se vê como um importante ator capaz de influenciar e alterar uma determinada situação. Nesse aspecto, Sé (1999) e Gonzaga (2003) demonstraram que a EA escolar, quando pautada no pleno envolvimento e participação da comunidade escolar (que em suas pesquisas incluía crianças e jovens), contribui para a formação integral do educando, indo além da consciência ambiental, também para a noção de organização e mobilização que constituem a participação política.

Os impactos ambientais no meio urbano resultam principalmente da precariedade dos serviços e da omissão do poder público, porém, muitas vezes são também reflexo do descuido e da omissão dos próprios moradores, comprometendo aspectos de interesse coletivo. A postura de conformismo e/ou de omissão da população são frutos principalmente da desinformação, da falta de consciência ambiental e da inexistência de práticas comunitárias das EaDs na participação e no envolvimento dos cidadãos (TÓRO-TONISSI, 2005).

Incentivar a participação dessas pessoas em todas as questões ambientais e mais especificamente nas relacionadas ao planejamento urbano para a manutenção ou recuperação da qualidade ambiental da cidade, é um importante papel da Educação Ambiental. Esse processo de envolvimento da comunidade deve contribuir para que esta se torne sensibilizada, bem informada, consciente de seu papel e de seu poder de mobilização e de intervenção na realidade, e motivada para agir.

Nesse sentido, a escola é um terreno fértil para a prática da Educação Ambiental, pois como instituição co-responsável pela formação integral das crianças e jovens, deve esclarecer a interdependência entre todos os elementos (bióticos e abióticos) de um ecossistema e promover o respeito e o cuidado para com o ambiente, além de motivar a participação responsável nas questões ambientais. Nesse contexto, a Educação Ambiental é um 
instrumento fundamental de incentivo ao desenvolvimento de uma nova cultura de direitos baseada na motivação e na co-participação da gestão ambiental das cidades e das bacias hidrográficas (TÓRO-TONISSI, 2005).

Nas escolas, as reflexões sobre "Meio Ambiente" devem abranger todas as séries, para que esse Tema Transversal possa estar presente em todo o período de desenvolvimento da criança e do jovem, consolidando a compreensão do papel individual e coletivo na conservação ambiental. Somente quando acredita em seu poder de transformação da realidade, o indivíduo se sente responsável por essa mudança. 


\section{OBJETIVOS}

\section{Objetivo geral}

Pretende-se despertar nos professores o interesse pela educação ambiental como subsídio à cidadania por meio da formação continuada de professores do Ensino Fundamental utilizando através do Ensino a Distância - EaD.

\section{Objetivos específicos}

Aplicar o conteúdo do caderno do CECEMCA Áreas Verdes para professores do Ensino Fundamental do município de Alfenas - MG por meio de curso presencial e curso a distância $(\mathrm{EaD})$ com o objetivo de dinamizar a relação ensino-aprendizagem.

Avaliar a importância do trabalho de campo como um recurso fundamental na análise da paisagem.

Avaliar os dois módulos do curso, presencial e a distância, seus potenciais e limitações. 


\section{CAPÍTULO 1 - CONSIDERAÇÕES INICIAIS SOBRE A FORMAÇÃO DE PROFESSORES}

A formação de professores assume, sem dúvida, posição de relevância nas discussões relativas à educação. Esta é uma preocupação evidenciada nas investigações mais recentes e na literatura da área, provocando debates e encaminhando propostas acerca da formação inicial e continuada de docentes (PORTO, 2000).

Concepções diferentes sobre formação confrontam-se no âmbito educacional, originadas em diferentes pressupostos filosóficos. Essas concepções podem ser reunidas em duas grandes tendências. A primeira identificada como estruturante: formação tradicional, comportamentalista, tecnicista, define previamente programas, procedimentos e recursos; a segunda, interativo-construtivista: dialética, reflexiva, crítica, investigativa, organiza-se a partir dos contextos educativos e das necessidades dos sujeitos a quem se destina. Convém destacar que a discussão aprofundada dessas tendências não é o objetivo principal desse trabalho, tendo sido citadas com a finalidade de servir de base para as reflexões posteriores. Portanto, uma discussão mais aprofundada desse tema pode ser encontrada dentre outros, em Porto (2000).

Os termos reciclagem, treinamento, capacitação, educação permanente, formação continuada e educação continuada são comumente utilizadas como sinônimos, mas ao analisar cada um, percebe-se que estes são compartimentados e ocorrem depois do processo de formação inicial e assim se caracteriza como processo de formação contínua do professor, pois este prolonga depois de sua formação inicial. (LEITE, 2008)

A formação não se constrói por acúmulo (de cursos, de conhecimentos ou de técnicas), mas, sim, através de um trabalho de reflexão crítica sobre as práticas de (re)construção permanente de uma identidade pessoal (NÓVOA, 1995).

Portanto, o conceito de formação docente deve relacionar-se ao de aprendizagem permanente, que considera "os saberes e as competências docentes como resultados não só da formação profissional e do exercício da docência, mas também de aprendizagens realizadas ao longo da vida, dentro e fora da escola" (MIZUKAMI et al, 2003, p. 31).

Aprender a ser professor ocorre por meio de situações práticas que sejam efetivamente problemáticas, o que exige o desenvolvimento de uma prática reflexiva competente (MIZUKAMI et al, 2003, p. 12). 
Torna-se possível, a partir dessa lógica, relacionar a formação de professores com o desenvolvimento pessoal (produzir a vida do professor), com o desenvolvimento profissional (produzir a profissão docente) e com o desenvolvimento organizacional (produzir a escola) (NÓVOA, 1995).

Há, também, a necessidade de existir uma interconexão entre o currículo da formação inicial de professores e o currículo da formação permanente de professores. Nesta perspectiva não se deve pretender que a formação inicial ofereça produtos acabados, encarando-a antes como a primeira fase de um longo e diferenciado processo de desenvolvimento profissional (GARCÍA, 1995).

Decorrente disso, quando se reconhecem as deficiências científica e conceitual dos programas de formação de professores, conclui-se que é necessário situar a reflexão para além das abordagens tradicionais, sugerindo novas maneiras e pensar tal problemática (NÓVOA, 1995).

Para tanto, é preciso que os formadores de professores favoreçam a tomada de consciência dos professores em formação, sobre como se aprende e como se ensina; que os levem a compreender a própria prática e transformá-la a favor do desenvolvimento de seus alunos (ALMEIDA, 2000).

A formação de professores deve coincidir com uma formação contínua e centrada na atividade cotidiana da sala de aula, próxima dos problemas reais dos professores, tendo como referência central o trabalho de equipes docentes, assumindo, portanto, uma dimensão participativa, flexível e ativa.

Deste modo, mais do que os termos aperfeiçoamento, reciclagem, formação permanente, convém prestar atenção especial ao conceito de desenvolvimento profissional dos professores, por ser aquele que melhor se adapta à concepção do professor como profissional do ensino (GARCIA, 1995).

A formação deve ser coerente com um paradigma de preparação de professores crítico-reflexivos, comprometidos com o próprio desenvolvimento profissional e que se envolvam com a implementação de projetos em que serão atores e autores da construção de uma prática pedagógica transformadora (ALMEIDA, 2000).

Nessa mesma perspectiva, Nóvoa (1995) enfatiza que a formação passa pela experimentação, pela inovação, pelo ensaio de novos modos de trabalho pedagógico e por uma reflexão crítica sobre a sua utilização. A formação passa por processos de investigação, diretamente articulados com as práticas educativas. 
Em educação, os estudos sobre inovação começam a surgir em uma época recente; paulatinamente, passa-se a considerar a inovação como algo necessário para superar a continuidade de modelos educativos e pedagógicos. Esse interesse, todavia, não tem conduzido a uma análise aprofundada da questão. É comum, ainda, o tratamento semelhante para mudança e inovação, o que pode resultar em procedimentos pouco significativos para o propósito de melhoria da formação e da prática pedagógica (PORTO, 2000).

Assim, nessa perspectiva, a inovação não se caracteriza como aplicação de conhecimento produzido fora da escola e alheio à experiência do professor, ela nasce de sua reflexão sobre a prática e do intuito em questioná-la e compreendê-la a partir do contexto em que habitualmente ocorre. Destaca-se, ainda, que a inovação da formação e da prática pedagógicas não pode consistir apenas em propósito e intenção, mas sim, precisa transformarse em movimento construtivo ininterrupto, criador de novos focos de indagação, estimulador de novos achados, propiciador de novos fazeres. Então, formação e prática pedagógicas devem estimular a criatividade no contexto em que emergem e se concretizam, possibilitando a geração de propostas inovadoras e contribuindo para o processo de mudança (PORTO, 2000).

Para a formação de professores, o desafio consiste em conceber a escola como um ambiente educativo, onde trabalhar e formar não sejam atividades distintas. A formação deve ser encarada como um processo permanente, integrado no dia-a-dia dos professores e da escola.

Mizukami et al (2003) destaca que o objetivo de nossas políticas educacionais atuais consiste na desvalorização da formação inicial dos professores e no incentivo à formação continuada. É consenso que a formação inicial deve ter uma posição de prevalência nas discussões, porém, da mesma forma, entende-se que, como a formação acontece de maneira indissociável da experiência de vida e que a formação do professor, é processo que não se finaliza com a formação inicial, também se torna indispensável a formação continuada. Isso implica que se instale uma nova lógica de formação do professor e um novo significado da prática pedagógica.

Ao conceituar a formação continuada de professores torna-se necessário situá-la, originalmente, como processo de desenvolvimento que ocorre ao longo da vida profissional, em continuidade com formação inicial e em estreita relação com a prática pedagógica (PORTO, 2000).

Considerando que a formação de um profissional (seja qual for a área de atuação) configura-se como um processo contínuo, que deve acompanhar toda a sua trajetória, é 
indiscutível a necessidade de ações educacionais voltadas para o chamado processo de formação continuada. Desse modo, a formação continuada ocupa lugar de destaque junto aos sistemas educacionais, estando, de forma crescente, associada ao processo qualitativo de práticas formativas e pedagógicas (PORTO, 2000; MONTEIRO; GIOVANNI, 2000).

A formação de professores ao longo dos anos tem se constituído uma das preocupações dos sistemas educativos que, de um modo geral, consideram tanto a formação inicial quanto a formação contínua (ou continuada), como formação permanente.

A formação contínua, definida como o conjunto de atividades que se realizam após a formação inicial, que tem como objetivo desenvolver os conhecimentos e as competências dos professores tendo em vista o seu aperfeiçoamento profissional, é diferente de país para país, embora haja concordância quanto ao fato de se perspectivar como uma forma de educação permanente, pessoal e profissional (RODRIGUES; ESTEVES, 1993).

Ferry (1983), para quem a formação pode definir-se como "um processo de desenvolvimento individual destinado a adquirir ou aperfeiçoar capacidades”, enquadra esta noção, de acordo com três ópticas: como estratégia; como processo de desenvolvimento e como instituição.

A formação é entendida como uma estratégia que as instituições de formação põem em prática, partindo do princípio que há necessidades objetivas de formação em função das próprias necessidades da instituição. Nesse sentido, os formadores transmitem conhecimentos e saberes, procurando que os formandos se adaptem às exigências da instituição onde estão inseridos (SILVA, 2000).

Como processo de desenvolvimento, a autora acima citada define que a formação representa um processo de desenvolvimento: os indivíduos integram as aprendizagens formais e informais com a sua experiência de vida, isto é, os sujeitos são os agentes da sua própria formação.

A formação entendida como instituição, identifica-se com instituição formadora, conotando-se com a estrutura institucional, ou seja, o edifício, os horários, os programas, as normas, os modelos, os formadores.

A Lei de Diretrizes e Bases da Educação Nacional (Lei nº 9.394/96), no Brasil, reconhece o direito a "programas de formação continuada para os profissionais de educação dos diversos níveis" (BRASIL, 1996). No entanto não há, por enquanto, dispositivos legais em relação ao Estado e à cidade de São Paulo, que legislem processos sobre formação contínua. Apesar disso, esse modelo de formação tem sido adotado com regularidade por sistemas de ensino, sem, contudo, resultar em dispositivos de progressão na carreira docente. 


\section{1 - A formação continuada de professores através da Educação Ambiental - EA}

Desde os anos 1970, significativas transformações nas esferas econômica, política, sócio-cultural e ambiental, tem ocorrido tanto no cenário internacional quanto no nacional. Essas transformações, configuradas pela reestruturação produtiva do processo capitalista, encerradas sob os ditames do pensamento neoliberal e do processo de globalização, desestruturam conquistas sociais importantes e tornam ainda mais evidentes quão frágeis são a economia, a política e a organização social da maioria dos estados nacionais do Planeta. Boff (1999) afirma que aqueles que detêm o monopólio do ter, poder e saber controlam não apenas os mercados, mas também todas as estruturas que garantem a manutenção e a disseminação das ideologias dominantes. Nesse cenário, a educação e o ambiente obviamente não escapam a este tipo de lógica.

Durante certo tempo, a educação ambiental restringiu-se a cumprir seu papel na perspectiva preservacionista. No entanto, instada a transitar na complexa organização de conhecimentos políticos, éticos, econômicos, culturais e outros, impôs-se transcender ao reducionismo das práticas esporádicas, relacionadas a datas comemorativas, a desenvolvimento de miniprojetos específicos, a cuidados com hortas e jardins, ao cultivo de plantas medicinais, à reciclagem de lixo e materiais, ou a anúncios e denúncias das consequiências das ecocatástrofes. Tais práticas não produziram, efetivamente, alterações nos padrões de consumo e na maneira de viver da sociedade globalizada. Mais do que isso, as pessoas que assim praticavam educação ambiental foram associadas a causas e movimentos que tinham rótulos pejorativos (dentre estes, o termo "ecochatos"), pois na verdade, não desenvolviam consciência, não mudavam hábitos e atitudes e não educavam; e, se não educavam, não refletiam; e, se não refletiam, não transformavam (GOUVÊA, 2006).

Para Leff (2001), a educação ambiental deveria tentar articular, subjetivamente, o educando ao conhecimento, bem como suas formas de produção, a descobrir os sentidos e sabores do saber, a desenvolver, mais que o pensamento crítico, um pensamento reflexivo e prospectivo capaz de combater condutas automatizadas, o pragmatismo e o utilitarismo tão presentes na sociedade globalizada moderna.

Nesse sentido, vários questionamentos tornam-se aparentes: o educador considera as implicações ideológicas, políticas, econômicas e éticas do trabalho educativo que está realizando, na perspectiva ambiental? Estará construindo a prática da educação ambiental com a consciência da complexidade do processo educativo? O que acontecera com a formação de professores em função da prática de educação ambiental? 
Com essas preocupações em mente, fez-se uma reflexão inicial sobre a educação ambiental, resgatando o pensamento de Carvalho (2004) em que toda educação é ambiental, pois se assim não se proceder, perde-se o sentido de educar. Seguindo este posicionamento profissional, percebe-se que, a formação de professores deve orientar-se para contextos diferenciados e intrinsecamente interligados: social, político e pedagógico.

$\mathrm{O}$ fato mencionado de que professores trabalhem a educação ambiental preferencialmente com o viés ecológico, pode advir de dois fatores: o primeiro, já ressaltado neste trabalho, diz respeito à questão da formação do professor, uma vez que esta se desenvolve, no contexto atual, com um forte componente fragmentador, o que direciona uma prática também fragmentada, gerando a não valorização da educação como processo integral; o segundo, um resquício histórico, para o qual a questão da educação ambiental se configura com o mesmo tratamento dado pelos movimentos ambientalistas - de forma puramente preservacionista. Esta visão preservacionista se encontra presente na maioria dos livros didáticos, nas obras que dissertam sobre o tema e mesmo na Legislação Brasileira - Política Nacional de Meio Ambiente (Lei 6.938/81), a Constituição Federal, a Política Nacional de Educação Ambiental (Lei 9.795/99), entre outras (GOUVÊA, 2006).

A necessidade de compreender educação ambiental como um processo educativo amplo e permanente, necessário à formação do cidadão, torna-se um fator essencial tanto para a qualidade da educação, como para o direcionamento da formação do docente, pois a abordagem disciplinar não abrange a complexidade do processo educativo. A educação não pode ser vista como uma atividade redentora e nem tampouco uma forma de ascensão social. Como defende Gimeno (2002,), a educação é um "projeto reflexivamente dirigido, como um instrumento para construir [...] pilares da humanização".

Ao perceber a educação como um direito da cidadania, é pertinente também considerar que ela pode contribuir para a conquista desse princípio ao incentivar discussões, participação, reivindicações, assim como ações concretas e engajamento responsável e ético de cada um, enquanto sujeito e enquanto coletividade.

A educação ambiental está ligada aos conceitos ou representações que foram atribuídos ao Meio Ambiente. Por ser interdisciplinar, muitas vezes o professor de séries iniciais, ao desenvolver conteúdos de suas disciplinas, está trabalhando conceitos de Educação Ambiental, mas não os percebe. Os trabalhos em Educação Ambiental devem desenvolver a sensibilidade, responsabilidade, competência e cidadania ambiental, o que vai além da sala de aula (TAVARES, 2003). 
A Educação Ambiental deve estar presente em todos os espaços que educam o cidadão e a cidadã. Desta forma, ela pode estar presente nas Escolas, nas Associações de Bairro, nas Universidades, nos Meios de Comunicação, Sindicatos, Parques e Reservas Ecológicas, de modo que cada um desses contextos possa contribuir com suas peculiaridades para a diversidade e criatividade da mesma, na busca de soluções possíveis para a problemática do meio ambiente (TAVARES, 2003).

Segundo Reigota (1994), a escola pode ser considerada como um dos locais privilegiados para a consecução da Educação Ambiental, que com a perspectiva de educação, deve permear todas as disciplinas, enquanto enfocar as relações entre a humanidade e o meio natural. Cada disciplina tem sua contribuição a dar nas atividades de Educação Ambiental, envolvendo professores de todas as áreas de conhecimento. Entretanto, a busca de soluções de problemas ambientais precisa de uma maior integração interdisciplinar para a busca do conhecimento.

A formação e a capacitação de docentes para a Educação Ambiental é, na atualidade, objetivo reconhecido e inclusive prioritário de muitas administrações educativas assim como de numerosas instituições públicas ou privadas, sensíveis a esta necessidade.

De acordo com Marcelo (1999), é uma tarefa complexa que não pode ser abordada sem contextualizá-la nos problemas gerais do sistema educativo, nas políticas de desenho de currículos e nas específicas características da Educação Ambiental.

Há um reconhecimento da comunidade ligada aos setores educacionais de que a Educação Ambiental é necessária para se alcançar o ideal de sociedades sustentáveis. Isso é verificado via formulação recente de políticas públicas, difusão da temática em diferentes movimentos sociais e propostas de incorporação do estudo do ambiente associado à ciência, tecnologia e sociedade no âmbito escolar. Nesse sentido a preparação de professores com competência para atuarem como agentes de mudança tem sido considerada prioritária (Tilbury, 1992; Fien; Rawling, 1996). Há também um amplo entendimento de que tal formação é bastante complexa face ao conhecimento, atitudes e habilidades exigidos para se alcançar a variedade de objetivos e metas da Educação Ambiental.

Entre os vários obstáculos encontrados na adoção de mudanças na prática escolar Fien, Rawling (1996) apontam: a idéia equivocada de que Educação Ambiental é tema somente para aulas de Ciências e Biologia; as limitações decorrentes dos aspectos infra-estruturais, tais como falta de recursos didáticos específicos, tempo para preparação coletiva de novas propostas metodológicas e grande número de alunos por sala; a supervalorização da 
transmissão de informações, e as políticas institucionais contrárias a um trabalho orientado para mudança de valores e atitudes diante da realidade.

\section{2 - A formação continuada de professores através da Educação à Distância (EaD)}

A EaD, enquanto modalidade de ensino, pode contribuir para um processo mais flexível e autônomo, porém, Preti (2005) alerta para que isto não fique apenas nas práticas discursivas das instituições. $\mathrm{O}$ autor fala ainda do equívoco conceitual ao se utilizar o termo "autonomia" como sinônimo de autodidatismo, capacidade de a pessoa estudar por conta própria. Segundo ele, só esta característica não basta para garantir a autonomia.

\footnotetext{
"Em nosso entender, isso não é suficiente. Tem de ser levado em conta o contexto histórico-cultural em que ocorrem esses processos formativos, para se compreender as limitações e as possibilidades de práticas pedagógicas como colaboradoras no processo de construção da autonomia do aluno, em suas diferentes dimensões e não somente limitada à aprendizagem autônoma, ao estudo independente" (PRETI, 2005, p.129).
}

Para Preti (2005), é possível organizar um sistema de apoio ao estudante e um ambiente pedagógico que favoreça sua caminhada coletiva e individual no curso, através de recursos humanos, de sistemas de avaliação e de acompanhamento, apoiados em abordagens interacionistas.

De acordo com Alonso (2005), os pressupostos das propostas dos sistemas presenciais ou a distância são basicamente os mesmos, ambos podem apresentar caráter inatista, empirista ou interacionista, dependendo dos princípios estabelecidos no projeto educacional. Porém, o $\mathrm{EaD}$ apresenta alguns problemas que lhe são específicos

“[...] elementos como o acompanhamento sistemático dos alunos, a disponibilização de meios, o apoio institucional aos estudantes, dentre outros, incidem, fortemente, na permanência do público que se utiliza da EaD” (ALONSO, 2005, p. 164).

Portanto, a EaD, antes de preocupar-se com a quantidade (educação de massa), deve priorizar a qualidade do ensino em questão. Desta forma, trabalhar com um grupo muito grande de alunos pode comprometer e prejudicar o processo de ensino-aprendizagem, já que limita um acompanhamento mais personalizado, uma interação constante e dificulta o estabelecimento de vínculos entre o grupo. 
É muito importante que os cursos de formação continuada de professores na modalidade $\mathrm{EaD}$, assim como os presenciais, tenham bem definidos os seus objetivos e que estes estejam embasados em uma proposta sólida de educação. É preciso se pensar na EaD agregada a um projeto educacional que além de atender as peculiaridades que esta modalidade implica, venha refletir acerca dos processos de formação, considerando como os docentes tecem seus conhecimentos e constroem suas práticas educativas.

Atualmente, a informação não é mais um objetivo privilegiado da educação, pois acabou o tempo em que a escola era o principal lugar de aquisição de informações. Com a difusão acelerada das informações por meio das Tecnologias da Informação e Comunicação (TICs), estas deixaram de ser privilégio de poucos (os mestres) e se transformaram em parte integrante da cultura mundial, facilmente acessível a uma parcela da população, dentro de certas condições (NOVA; ALVES, 2003).

Na opinião de Kenski (2003b), com o avanço da tecnologia nos dias atuais o professor precisa saber dispor das novas tecnologias de comunicação e informação (televisão, vídeo, computador, Internet, sem esquecer das possibilidades do rádio e da mídia escrita), e conhecer suas especificidades, possibilidades e limites para utilizá-las adequadamente de acordo com os temas e as necessidades de ensino de um determinado grupo de alunos.

Porém, apenas a existência da infra-estrutura dos equipamentos não garante a almejada qualidade pedagógica para o desenvolvimento das atividades em aula. É preciso muito mais: que os professores possam ter domínio e fluência tecnológica para trabalhar com a multiplicidade de tecnologias de informação e comunicação (KENSKI, 2003b). É preciso, primeiramente, uma familiarização do professor com as novas tecnologias e, para que isso ocorra, as atividades de aproximação entre professores e tecnologias devem ser realizadas, de preferência, na formação inicial de professores (licenciaturas) (KENSKI, 2003a).

Conforme destaca Moran (2005), na medida em que avançam as tecnologias de comunicação, o conceito de presencialidade também se altera. Existirá, assim, uma troca maior de saberes, possibilitando que cada professor colabore, com seus conhecimentos específicos, no processo de construção do conhecimento, muitas vezes a distância. Nesse processo, o papel do professor vem sendo redimensionado e cada vez mais ele se torna um supervisor, um animador, um incentivador dos alunos na estimulante experiência da informação.

A EaD não é um modismo: é parte de um amplo e contínuo processo de mudança, que inclui não só a democratização do acesso a níveis crescentes de escolaridade e atualização permanente como também a adoção de novos paradigmas educacionais, em cuja base estão os 
conceitos de totalidade, de aprendizagem como fenômeno pessoal e social, de formação de sujeitos autônomos, capazes de buscar, de criar, de aprender ao longo de toda a vida e de intervir no mundo em que vivem (NEVES, 2007).

No caso do Brasil, os cursos oferecidos a distância destinados a formar e aperfeiçoar professores podem chegar aos mais longínquos lugares do país (80\% dos 27.000 alunos do Proformação ${ }^{1}$ eram da zona rural), o que demonstra seu potencial de democratizar a educação. Podem também ser uma excelente estratégia de construir ao mesmo tempo conhecimento, dominar tecnologias, desenvolver competências e habilidades e discutir padrões éticos que beneficiarão, mais tarde, os alunos desses professores. Ou seja, um bom curso a distância oferece aos seus participantes não só autonomia para aprender sempre, como deixa o profissional preparado para trabalhar com seus alunos de uma forma mais rica, moderna, dinâmica (NEVES, 2007).

Isso, no entanto, só acontece quando o programa de EaD é comprometido com qualidade. E qualidade em EaD é como uma "rede de pesca": vários nós que se unem para alcançar um objetivo. A fragilidade em um dos nós pode comprometer o resultado final (NEVES, 2007).

1 PROFORMAÇÃO - Programa da Secretaria de Educação a Distância, é um curso em nível médio, com habilitação para o magistério na modalidade Normal, realizado pelo MEC em parceria com os estados e municípios. Destina-se aos professores que, sem formação específica, encontram-se lecionando nas quatro séries iniciais, classes de alfabetização ou Educação de Jovens e Adultos - EJA das redes públicas de ensino do país (BRASIL, 2007). 


\section{CAPÍTULO 2 - EDUCAÇÃo A DISTÂNCIA (EaD) ENQUANTO MODALIDADE EDUCATIVA}

A Educação a Distância $(\mathrm{EaD})$ é uma modalidade educativa diferente das demais pelas peculiaridades que a caracteriza e a distingue. Embora não sendo uma novidade, apresenta-se hoje como uma opção eficiente, pois é capaz de atender a uma demanda por democratização do saber, por educação continuada e constitui, para o universo educacional, um fenômeno da modernidade. Numa definição considerada clássica apresentada por Aretio (apud Landin, 1997, p. 30), educação a distância é:

"Sistema tecnológico de comunicação bidirecional, que pode ser massivo e
que substitui a interação pessoal, na sala de aula, de professor e aluno, como
meio preferencial de ensino, pela ação sistemática e conjunta de diversos
recursos didáticos e pelo apoio de uma organização e tutoria que propiciam a
aprendizagem independente e flexível dos alunos."

Segundo MOORE e KEARSLEY (1996) o conceito fundamental de EaD coloca o estudante e o professor separados fisicamente e, na maioria das vezes, também temporalmente. Moore e Kearsley (1996, p. 11), apresentam uma definição para EaD:

"Educação à distância é a aprendizagem planejada que geralmente ocorre
num local diferente do ensino e, por causa disso, requer técnicas especiais de
desenho de curso, técnicas especiais de instrução, métodos especiais de
comunicação através da eletrônica e outras tecnologias, bem como arranjos
essenciais organizacionais e administrativos. (MOORE, KEARSLEY,1996,
p.11)."

Urdan e Weggen (2000, p. 88) definem EaD da seguinte forma:

"Situação educacional na qual o instrutor e o estudante estão separados pelo
tempo, localização geográfica, ou ambos. A educação ou o curso de
treinamento são entregues em locais remotos via meios de comunicação
síncrono ou assíncrona, incluindo correspondência escrita, textos, gráficos,
áudio e vídeo tape, CD-ROM, aprendizado online, áudio e vídeo
conferências, TV interativa e fax."

Palloff e Pratt (1999) explicam os cinco elementos fundamentais para definir EaD: a separação do professor e do aprendiz durante pelo menos a maior parte de cada processo instrucional; a utilização de uma mídia educacional para unir professor e aprendiz e "transportar" o conteúdo do curso; a disponibilidade da comunicação de mão dupla, onde o 
estudante se beneficia de um diálogo e da possibilidade de iniciativas de comunicação; separação do professor e aluno em espaço e/ou tempo; aprendizado controlado pelo estudante e não pelo professor (tutor) que se encontra a distância. Portanto, pode-se dizer de uma forma mais ampla que Educação a Distância é uma modalidade de ensino-aprendizagem caracterizada pela distância geográfica que separa aluno e professor e onde a interatividade entre ambos é facilitada por algum tipo de tecnologia (VEIGA et al, 1998; NISKER, 1999).

Na visão de Landim (1997), educação é a prática educativa na sua essência, o processo ensino-aprendizagem que leva o indivíduo a aprender a aprender, a saber pensar, criar, inovar.

É um processo de humanização que alcança o pessoal e o estrutural, partindo da situação concreta em que se dá a ação educativa numa relação dialógica. Portanto, quando falamos em educação estamos nos referindo a todas as concepções que ela nos envolve na vida, nas relações sociais, pessoais, políticas e juntamente com a natureza. Está misturada em tudo, faz parte do todo (PRETI, 2001). Desta forma, falar em Educação a Distância não implica em se prender à palavra "distância", mas sim ao processo educativo envolvido por uma abordagem mais contextualizada, situada.

Keegan (1996) apresenta como elementos, que considera centrais na $\mathrm{EaD}$, a separação física entre professor e aluno, que a distingue do ensino presencial; a influência da organização educacional (planejamento, sistematização, plano, projeto, organização dirigida), que a diferencia da educação individual e a utilização de meios técnicos de comunicação, usualmente impressos, para unir o professor ao aluno e transmitir os conteúdos educativos. Além desses elementos, o autor considera a previsão de uma comunicação de mão dupla, em que o estudante se beneficia de um diálogo e da possibilidade de iniciativas de dupla via, a possibilidade de encontros ocasionais com propósitos didáticos e de socialização e a participação de uma forma industrializada de educação.

O desenvolvimento atual da tecnologia favorece a criação e o enriquecimento das propostas na $\mathrm{EaD}$, na medida em que permite abordar, de maneira ágil, inúmeros temas, assim como gerar novas formas de aproximação entre professor e aluno, e de alunos entre si.

Para Oliveira (2001), a Educação a Distância é norteada por princípios cujas características permitem delinear essa modalidade de Educação. Os princípios apresentados pelo autor e suas respectivas características são apresentados na Tabela 1. 
Tabela 1: Princípios da Educação a Distância

\begin{tabular}{|c|c|}
\hline PRINCÍPIOS & CARACTERÍSTICAS \\
\hline Democratização & $\begin{array}{l}\text { Igualdade de oportunidades. Atende a uma população dispersa } \\
\text { geograficamente, oferecendo oportunidades àqueles que não } \\
\text { puderam iniciar ou concluir seus estudos, garantindo a } \\
\text { permanência dos alunos em seu próprio ambiente cultural. }\end{array}$ \\
\hline Individualização & Atenção singular a cada sujeito em seu marco contextual. \\
\hline Autonomia & $\begin{array}{l}\text { Consideração às iniciativas pessoais de cada sujeito e estímulo } \\
\text { ao seu desenvolvimento responsável. Permite que o aluno seja } \\
\text { um sujeito ativo na sua formação. Estimula a independência } \\
\text { intelectual: capacidade para pensar, trabalhar e decidir } \\
\text { alternativas viáveis para a superação de situações-problemas. }\end{array}$ \\
\hline Comunicação & $\begin{array}{l}\text { Intercâmbio de informações na perspectiva bidirecional, como } \\
\text { garantia de uma aprendizagem dinâmica e inovadora. O } \\
\text { afastamento entre professor e aluno é compensado pelo uso do } \\
\text { sistema multimídia, transformando-se a distancia em fator } \\
\text { positivo para o desenvolvimento da independência intelectual } \\
\text { do aluno. }\end{array}$ \\
\hline Socialização & $\begin{array}{l}\text { Estimula a cooperação solidária e construtiva, o } \\
\text { desenvolvimento da capacidade de participação social, } \\
\text { geração de espaços políticos e melhora dos entornos sociais e } \\
\text { físicos. }\end{array}$ \\
\hline Abertura & $\begin{array}{l}\text { Permite o aperfeiçoamento permanente. É uma atividade de } \\
\text { ampliação continua de horizontes pessoais, profissionais e } \\
\text { sociais. }\end{array}$ \\
\hline Criatividade & $\begin{array}{l}\text { Esforço contínuo de descobrimento, originalidade, reflexão e } \\
\text { busca de alternativas viáveis. }\end{array}$ \\
\hline $\begin{array}{l}\text { Educação } \\
\text { Permanente }\end{array}$ & $\begin{array}{l}\text { Possibilita alternativas de aperfeiçoamento continuo } \\
\text { profissional, a formação permanente e a promoção cultural. }\end{array}$ \\
\hline Flexibilidade & $\begin{array}{l}\text { Atende aos alunos nas mais diversas necessidades e situações, } \\
\text { possibilitando tempos, espaços, ações e processos que se } \\
\text { adaptem às exigências de cada um. }\end{array}$ \\
\hline
\end{tabular}

Fonte: OLIVEIRA (2001).

Em relação às vantagens e desvantagens da $\mathrm{EaD}$, cabe destacar a análise apresentada por Landim (1997), na qual expõe algumas considerações sobre essa questão. Nesse sentido, no que diz respeito aos pontos positivos da $\mathrm{EaD}$, o autor indica a possibilidade de Abertura, ou seja, reduzir as barreiras de acesso por cursos ou nível de estudos; diversificar e ampliar a oferta de cursos; dar oportunidade de formação às pessoas que não puderam frequientar a escola tradicional. Outro aspecto relevante é a Flexibilidade que representa a ausência de rigidez de espaço físico (onde estudar), ritmo (em que velocidade aprender) e ampliando o apoio às aulas e tempo (quando estudar). 
Landim (1997) chama atenção para a Eficácia da Educação a Distância, uma vez que o aluno vê respeitado o seu ritmo de aprender. Conteúdos instrucionais são elaborados por especialistas, assim como a utilização de recursos da multimídia; comunicação bidirecional freqüente, garantindo uma aprendizagem dinâmica e inovadora.

A Formação permanente e pessoal se constitui em importante aspecto que vem a atender às demandas do aluno através do intermédio de atividades formativas ou não; contribuindo para a formação de um aluno ativo o qual poderá desenvolver a iniciativa, atitudes, interesses, valores e hábitos educativos, capacidade para o trabalho e superação do nível cultural.

Por fim, a Economia se configura em uma das vantagens da $\mathrm{EaD}$, já que apresenta custos reduzidos em relação aos dos sistemas presenciais de ensino. No que tange às desvantagens e limitações da EaD, a autora Landim (1997) chama a atenção para a limitação em alcançar o objetivo da socialização da área afetiva/atitudinal e psicomotora. A autora também aponta que pode ocorrer o empobrecimento da troca direta de experiência educativa entre professor e aluno, e chama a atenção para o fato que alguns cursos necessitam que o aluno possua elevado nível de compreensão de textos e saber utilizar os recursos da multimídia.

Embora Landim (1997) exponha que se excetuando as atividades presenciais de avaliação, os resultados da avaliação a distância são menos confiáveis do que os da educação presencial, aponta a necessidade de um rigoroso planejamento a longo prazo, embora com a vantagem de um repensar e de um refletir por mais tempo. Um bom acompanhamento do processo minimiza a perda de alunos, e embora os custos iniciais para a implantação de Cursos a Distância sejam elevados, os mesmos podem ser reduzidos ao longo do curso. A autora especifica que a $\mathrm{EaD}$ pode contribuir significativamente para o desenvolvimento educacional de um país, especialmente daquelas cuja sociedade apresenta um sistema educacional problemático.

Frente ao potencial do desenvolvimento de modelos de educação alternativos e eficazes, passíveis de viabilização através da $\mathrm{EaD}$, cabe aos educadores e aos governantes verificar as possibilidades dessa modalidade junto aos sistemas de ensino, para que muitos realmente tenham acesso ao saber socialmente produzido e do qual a grande maioria da população fica excluída. 


\section{1 - Aspectos históricos sobre Educação a Distância (EaD)}

Fontes históricas revelam e defendem o surgimento da $\mathrm{EaD}$, no início do século $\mathrm{XV}$ quando Johann Guttemberg em Mogúncia, Alemanha, inventou a prensa tipográfica. No início do século XVII, o cientista inglês Francis Bacon via a tipografia como um meio para o progresso do conhecimento. Após a invenção da tipografia, os escribas temeram que a prensa lhes fosse tirar o ganha-pão. Para o clero, a tipografia causou problemas porque o novo meio de comunicação permitiu que gente comum estudasse os textos religiosos por sua própria conta e não dependesse daquilo que as autoridades lhe dissessem (ALVES, 1999).

Um primeiro marco da EaD foi o anúncio publicado na Gazeta de Boston, no dia 20 de março de 1728 pelo professor de taquigrafia Cauleb Phillips: “Toda pessoa da região, desejosa de aprender esta arte, pode receber em sua casa várias lições semanalmente e ser perfeitamente instruída, como as pessoas que vivem em Boston” (SARAIVA, 1996, p. 29).

O registro da primeira experiência nesse campo de ensino foi na Suécia, em 1833, através do curso de Contabilidade. Em 1840, na Inglaterra, a EAD é implementada pelo curso de estenografia.

A Alemanha fundou o primeiro instituto de ensino de línguas por correspondência: “L' Iinstitut Toussaint et Langenscheidt" - em 1856. Posteriormente, em 1873, nos Estados Unidos, notou-se o ensino por correspondência, através da Illinois Wesleyan University, sendo a primeira universidade aberta do mundo. O início da EaD no Brasil data provavelmente de 1904 (ALVES, 1999).

Lentamente, em diferentes partes do mundo foram criados estabelecimentos de ensino com a modalidade a distância gerando em grande parte das vezes, propostas diferentes nos próprios estabelecimentos tradicionais de ensino, os quais incorporaram-na como uma alternativa de estudos (LITWIN, 2001). Hoje, a EaD existe praticamente em quase todo o mundo, incorporada a sistemas de capacitação, mestrados e doutorados, demonstrando perfeitas condições para uma educação permanente.

Katz (1973) afirma que o primeiro curso por correspondência nos Estados Unidos foi de taquigrafia no ano de 1728. Castro e Guaranys (1977) registram um curso de taquigrafia, em 1840, na Inglaterra, e vários outros cursos por correspondência, no início do século XX, na Rússia e em, pelo menos, oito universidades americanas, Wisconsin, Oregon, Kansas, Minnesota, Nebraska, Texas, Missouri, e North Dakota. Rapidamente várias iniciativas de criação de Cursos a Distância se espalharam. Os mais bem sucedidos eram os do tipo extensão universitária ou cursos técnicos. Havia uma grande resistência com relação a cursos 
universitários a distancia, razão pela qual poucas foram as experiências duradouras, mesmo nos paises mais desenvolvidos.

A utilização da televisão como ferramenta de $\mathrm{EaD}$ é bem documentada na literatura. Shulman (1981) registra que na década de 1950 cerca de 114 faculdades independentes e universidades americanas já mantinham, com sucesso, aulas por TV, combinando-as, às vezes, com aulas presenciais. Durante algum tempo, os cursos por TV entraram em declínio, mas o advento do video-tape e do satélite os reativaram. Em 1979, cerca de $71 \%$ das universidades americanas ofereciam cursos por TV em circuito fechado.

As primeiras ocorrências da $\mathrm{EaD}$ são registradas a partir do final do século XIX, sendo que as mesmas eram realizadas por meio do estudo por correspondência. A principal mídia utilizada era o material impresso, apresentado sob a forma de guias de estudos com composições escritas ou outras tarefas enviadas pelo correio.

Uma ressalva importante sobre o material impresso é que ele tem uma função importante em todo o caminho seguido pela prática educativa, pois, desde a invenção da imprensa no século XV, utilizou-se muito desse meio, e o livro constituiu o único meio adicional de ensino, além do professor e da lousa, por um longo tempo.

Em 1969, criou-se a primeira instituição que oferecia EaD, a Universidade Aberta Britânica (British Open University). A partir de então começaram a surgir instituições de ensino universitário e não-universitário, assim como associações de Educação a Distância em vários outros países (Landim, 1997).

A partir desse momento, características como a autonomia do aluno e sua independência tornaram-se mais acentuadas. Paralelamente à evolução tecnológica, principalmente a computacional, a EaD ganhou melhores condições para atender aos alunos, disseminar o conhecimento de forma eficiente e também contou com novas alternativas para apresentar os conteúdos.

Desde o final de 1960, usava-se a combinação de recursos multimídia, material impresso, computador, fita cassete e transmissão de rádio e televisão (NIPPER, 1989). Assim, a EaD deu um salto considerável na maneira de disseminar os conhecimentos, pois, com o uso de mídias que estimulavam sensoriamente (devido aos recursos imagéticos e sonoros), o engajamento dos alunos era maior.

Desde 1990 a EaD tem se baseado nas tecnologias de comunicação interativa, além de apresentar uma utilização intensa da informática: internet, estações de trabalho multimídia, redes telemáticas, banco de dados, correio eletrônico, listas, fórum de discussão e videoconferência. Tais recursos permitem uma comunicação de dupla via entre aluno e 
professor, garantindo um retorno mais rápido e uma comunicação mais dinâmica entre os envolvidos, muitas vezes desejadas nos modelos anteriores.

Considerando o contexto da EaD, Belloni (1999) levanta uma preocupação importante: o perfil do aluno a distância. A literatura costuma apresentar um perfil de aluno autônomo, capaz de buscar seus próprios conhecimentos. De acordo com os resultados de uma pesquisa realizada por Walker (apud Belloni, 1999) com estudantes australianos, verificou-se uma realidade que não condizia com o que se esperava: uma imagem marcada pelo silêncio, tranqüilidade e solidão. Isso porque, em termos gerais, o perfil do aluno vinculado a cursos de Educação a Distância dá conta que na sua maioria são adultos, muitas vezes ativos profissionalmente e com pouca - ou nenhuma experiência no uso de tecnologias, principalmente Internet e e-mail.

Dentre outras experiências, é claro verificar que se não houver um acompanhamento de uma equipe especializada aos alunos, é inevitável que estes se sintam desmotivados e abandonados no decorrer do curso.

Assim, a motivação no contexto educacional é fator determinante para o sucesso do aluno. Ele deve ter suas necessidades atendidas, e, nesse sentido, Belloni (1999) afirma que os "sistemas educacionais terão que enfrentar as novas demandas daí decorrentes, e então será essencial conhecer as expectativas e necessidades dos estudantes e conceber cursos, estratégias e metodologias que as integrem efetivamente".

No Brasil, a primeira experiência relevante ocorreu na década de 60, com as 6.218 escolas radiofônicas do Movimento de Educação de Base (MEB) ${ }^{2}$ (Cunha, 1985).

Os cursos por correspondência do Instituto Universal Brasileiro ${ }^{3}$ e os Telecursos ${ }^{4}$ de $1^{\circ}$ e $2^{\circ}$ Graus, da Fundação Roberto Marinho foram sinônimos de EaD no Brasil, praticamente até o final do séc XX. Em meados da década de 90, a internet trouxe um item fundamental para o processo de ensino aprendizagem à distância: a interatividade (CHEONG, 2002; DE

\footnotetext{
2 - O MEB é um organismo da Conferência Nacional dos Bispos do Brasil - CNBB, constituído como sociedade civil de direito privado, sem fins lucrativos, com sede e foro no Distrito Federal, tendo sido fundado em 21 de março de 1961. Tem por missão a promoção integral, humana e cristã de jovens e adultos, desenvolvendo programas de educação de base (CNBB, 2007).

${ }^{3}$ Fundado em 1941, o Instituto Universal Brasileiro é um dos pioneiros no Ensino a Distância no Brasil. Possui cursos profissionalizantes e cursos supletivos de ensino fundamental e ensino médio (INSTITUTO UNIVERSAL BRASILEIRO, 2007).

${ }^{4}$ O Telecurso 2000 é uma metodologia educacional que integra conteúdos do ensino fundamental e do ensino médio utilizando multimeios. A iniciativa oferece uma nova oportunidade de concluir os estudos básicos. Criado em 1995 pela Fundação Roberto Marinho e pela Fiesp, é o aperfeiçoamento de dois cursos anteriores: o Telecurso $1^{\circ}$ Grau e o $2^{\circ}$ Grau (FUNDAÇÃO ROBERTO MARINHO, 2007).
} 
LUCA, 2002). Assim, a EaD via internet começou a se colocar, em algumas situações, no mesmo patamar do ensino presencial.

\subsection{1 - Breve histórico da EaD no Brasil}

Uma das primeiras ações relacionadas à EaD que se tem ciência no Brasil data de 1923. Tendo como um dos principais objetivos o de promover educação pelo rádio, surgiu a Rádio Sociedade do Rio de Janeiro. Quatorze anos depois, em 1937, foi criado o Serviço de Radiodifusão Educativa do Ministério da Educação (NUNES, 2001).

No Brasil, as bases legais para a modalidade de Educação a Distância foram estabelecidas pela Lei de Diretrizes e Bases da Educação Nacional - Lei n ${ }^{\circ}$ 9.394, de 20 de dezembro de 1996, que em seu artigo 80 incentiva o desenvolvimento e a veiculação de programas de ensino a distância, em todos os níveis e modalidades de ensino, e de educação continuada, como destacado abaixo:

“Art. 80. O Poder Público incentivará o desenvolvimento e a veiculação de programas de ensino a distância, em todos os níveis e modalidades de ensino, e de educação continuada" (BRASIL, 1996).

Além disso, no artigo 87, reforça a necessidade de elevar o nível de formação dos profissionais, e determina cada Município e, supletivamente, o Estado e a União, deverá realizar programas de capacitação para os professores em exercício, utilizando também, para isto, os recursos da educação à distância (BRASIL, 1996).

O Decreto $n^{\circ} 5.622$, publicado no Diário Oficial da União de 20/12/05, regulamenta o art. 80 da Lei no 9.394, de 20 de dezembro de 1996. Em seu artigo $1^{\circ}$, caracteriza a Educação a Distância como modalidade educacional na qual a mediação didático-pedagógica nos processos de ensino e aprendizagem ocorre com a utilização de meios e tecnologias de informação e comunicação, com estudantes e professores desenvolvendo atividades educativas em lugares ou tempos diversos (BRASIL, 2005a).

O Art. $3^{\circ}$ do mesmo Decreto aponta para que a criação, organização, oferta e desenvolvimento de cursos e programas a distância observem ao estabelecido na legislação e em regulamentações em vigor, para os respectivos níveis e modalidades da educação nacional (BRASIL, 2005a).

O Decreto ${ }^{\circ}$ 2.494, de 10 de fevereiro de 1998 (publicado no Diário Oficial da União de 11/02/98), regulamenta o Art. 80 da Lei de Diretrizes e Base e, dentre outras coisas, enfatiza no seu Art. $1^{\circ}$ que a Educação a distância é uma forma de ensino que possibilita a auto-aprendizagem, com a mediação de recursos didáticos sistematicamente organizados, 
apresentados em diferentes suportes de informação, utilizados isoladamente ou combinados, e veiculados pelos diversos meios de comunicação (BRASIL, 1988).

A Associação Brasileira de Educação a Distância (ABED), foi criada em 1995, a partir de uma ação articulada entre a Escola do Futuro, da Universidade de São Paulo, e a Fundação Roberto Marinho. "É uma entidade sem fins lucrativos que tem como finalidades o estudo, pesquisa, promoção e desenvolvimento de projetos na área de Educação a Distância" (NUNES, 2001, p. 19).

Em termos universitários, uma das primeiras experiências em $\mathrm{EaD}$ ocorreu na Universidade de Brasília (UnB) em 1970. Motivada pelo sucesso da Open University, a UnB pretendia ser a Universidade Aberta do Brasil. Entretanto, questões políticas inviabilizaram o projeto na época (NUNES, 2001). Em 1992 um projeto de lei criando a Universidade Aberta de Brasília foi aprovado e sancionado pelo governador, conforme a lei no 403/92 (TORRES, 1994).

Uma das experiências mais recentes está na Universidade Federal de Santa Catarina, com o Laboratório de Educação a Distância (LED). Esse programa é hoje considerado referência nacional no uso de teleconferências juntamente com materiais impressos e com a internet para a condução de cursos (NUNES, 2001).

Criado em 1995 pelo Departamento de Engenharia de Produção, o LED oferece cursos em convênio com diferentes tipos de empresa, especialmente com faculdades particulares de vários estados do país (BELLONI, 1999).

Mais recentemente, no ano 2000, houve a criação de duas universidades abertas: a Universidade Virtual Pública do Brasil (UniRede), formada por iniciativa de instituições públicas de ensino, e a Universidade Virtual do Brasil (UVB), reunindo algumas universidades particulares do país (CERNY, 2001).

\section{2 - Ensino através da rede mundial de computadores - internet}

A partir da segunda metade do século XX, a evolução no tratamento da informação vem ocorrendo em diversas áreas, destacando-se, entre elas, as áreas de comunicação e de processamento de informações (SOARES et al, 1995). A conjunção destas duas áreas está revolucionando a sociedade atual, abrindo fronteiras com novas formas de comunicação, onde as redes de computadores atuam como uma das fontes propulsoras de uma nova ordem geopolítica (globalização), tecnológica - computação em rede aberta e centrada no usuário - e organizacional - mercado dinâmico, aberto e competitivo (TAPSCOTT; CASTON, 1993). 
Esta nova ordem está mudando o modo de trabalho das pessoas e, também, está reformulando as expectativas, necessidades, e oportunidades educacionais e de aprendizado (HÄMÄLÄINEN; WHINSTON; VISHIK, 1996; URDAN; WEGGEN, 2000).

A rede mundial de computadores, como também é conhecida, trouxe consigo um item fundamental para o processo de ensino aprendizagem à distância: a interatividade (CHEONG, 2002; DE LUCA, 2002).

Contudo, Urdan e Weggen (2000), Wentling et al. (2000) e Rosenberg (2002) destacam a utilização de Tecnologias de Informações (TIs) como sendo ferramentas capacitadoras para o $\mathrm{EaD}$, possibilitando a entrega do conteúdo e dos serviços disponíveis online. Portanto, o EaD caracteriza-se pela união da tecnologia (com destaque especial para a Internet), com conteúdo e serviços (HÄMÄLÄINEN; WHINSTON; VISHIK, 1996).

A Internet, conhecida como a maior implementação de redes de computadores interligados em rede (AMOR, 2000; LAUDON; LAUDON, 2001), é o conjunto (hardware e software) de TI que teve o maior crescimento e impacto social (VASSOS, 1997) nos últimos anos. Sua velocidade de expansão impressiona: atingiu 50 milhões de usuários em 5 anos, enquanto outras tecnologias ou formas de comunicação levaram bem mais tempo do que isso. A TV a cabo levou 10 anos para atingir 50 milhões de usuários; o computador levou 11 anos; a televisão, 18 anos; o telefone, 16 anos; e o rádio, 38 anos (GREENSTEIN; FEIMAN, 2000). Esse crescimento da Internet deve-se, em grande parte, ao surgimento do World Wide Web, também conhecido como www, w3 ou Web.

A Internet está trazendo vários benefícios para as organizações empresariais, governos e para a sociedade de um modo em geral. Dentre eles destacam-se: conectividade e alcance global; redução dos custos de comunicação; redução de custo de transação; redução de custo de operação; interatividade, flexibilidade e personalização e distribuição acelerada de conhecimento (AMOR, 2000; LAUDON; LAUDON, 2001).

Rosenberg (2002) acrescenta que a Internet é uma tecnologia unificadora que permite que o aprendizado ultrapasse as fronteiras geográficas e organizacionais, as culturas e fusos horários e classificação de clientes, transformando radicalmente o aprendizado nas organizações e levando a todos os envolvidos a avaliar novamente a sua função e seu objetivo.

Hämäläinen; Whinston; Vishik (1996), Strazzo; Wentling (2000) e Urdan e Weggen (2000) colocam que a Internet cria uma flexibilidade de tempo, localização, conteúdo e forma de instrução sem precedentes, onde os estudantes estão potencialmente hábeis a aprender o 
que eles precisam quando e onde eles quiserem e no formato mais apropriado a suas necessidades, o que está fortalecendo cada vez mais a EaD.

\section{3 - Conceitualização sobre qualidade em EaD}

$\mathrm{Na} \mathrm{EaD}$, a preparação do conteúdo instrucional constitui um desafio, pois cada conteúdo deve ser criado em formato específico, compatível com o suporte tecnológico, e armazenado em computador ou periférico ${ }^{5}$, como arquivo, para ser acessado tanto pelo aluno quanto pelo professor. É necessário trabalhar artisticamente o material didático, desenvolvido através de linguagem $\mathrm{HTML}^{6}$, e softwares ${ }^{7}$, PowerPoint ${ }^{8}$, entre outros programas, para tornálo mais atraente, comunicativo e eficaz. Por isso, grandes Centros de Educação a Distância têm criado equipes de especialistas para cuidar do material instrucional (VEIGA et al. 1988).

Para os autores acima citados, um sistema virtual de $\mathrm{EaD}$ pode obter ótimos resultados se incorporar o maior número de elementos do sistema de ensino tradicional tais como: Acessibilidade, entendida como a tecnologia para apoio à EaD deve estar sempre ao alcance do estudante não importando onde o mesmo se encontra; Um instrutor bem preparado aspecto essencial para controlar os conteúdos didáticos e promover a interação com os estudantes e entre eles. A ausência de um instrutor nos cursos assíncronos via CD pode explicar porque esses cursos são normalmente menos eficazes que as classes virtuais. Controle total do material didático pelo instrutor, a ponto de ele conseguir manter todos os estudantes "na mesma página". Alto nível de interatividade entre professor e alunos e entre os próprios alunos. Controle da situação num ambiente intelectual rico e dinâmico, desde que mantenha um ambiente de disciplina; Acesso a ricos recursos didáticos - por parte do instrutor e dos alunos; Verificação do processo de aprendizado em termos de rendimento e participação; Espontaneidade, oferecendo a improvisação de materiais didáticos para responder a perguntas inesperadas e mesmo para atualizar os participantes; Aprendizado auto-acompanhado - tornando-se disponível aos alunos todos os materiais do curso e promovendo-se sua capacidade de estudo independente. NEVES (2007) destaca que para sustentar a qualidade de um curso de formação de professores a distância devemos verificar:

\footnotetext{
${ }^{5}$ Dispositivo conectado a um computador que permita a comunicação ou iteração do mesmo com o mundo externo.

${ }^{6}$ HTML - HyperText Markup Language - Linguagem de Formatação de Hipertexto (USP, 2003).

${ }^{7}$ Software é uma sequência de instruções a serem seguidas e/ou executadas, na manipulação, redirecionamento ou modificação de um dado/informação ou acontecimento (UFRN, 2001).

${ }^{8}$ O PowerPoint é um programa que permite a criação e exibição de apresentações, cujo objetivo é informar sobre um determinado tema, podendo usar imagens, sons e textos que podem ser animados de diferentes maneiras (CENPEC, 2006).
} 


\section{- Concepção educacional do curso}

Um curso de formação de professores a distância está inserido nos propósitos da educação do país, com ela entrelaça seus objetivos, conteúdos, currículos, estudos e reflexões. Deve ser elaborado a partir de princípios filosóficos e pedagógicos citados nos guias e manuais, e colocados em prática ao longo de todo o processo.

Se o curso é apenas um conjunto de materiais xerocados, sem atividades que levem o professor a aplicar o que está aprendendo no seu cotidiano, se há pobreza de recursos e estratégias didáticas, se não provoca no aluno o interesse de interferir no seu meio, este pode ser um projeto sem qualidade.

\section{- Desenho do projeto: a identidade da educação à distância}

Programas, cursos, disciplinas ou mesmo conteúdos oferecidos a distância exigem administração, desenho, lógica, linguagem, acompanhamento, avaliação, recursos técnicos, tecnológicos e pedagógicos, que não são mera transposição do presencial. Ou seja, a EaD tem sua identidade própria.

Não há, porém, um modelo único de EaD. Os programas podem apresentar diferentes desenhos e múltiplas combinações de linguagens e recursos educacionais e tecnológicos.

A natureza do curso e as reais condições do cotidiano dos alunos é que vão definir a melhor tecnologia, a necessidade de momentos presenciais em estágios supervisionados, laboratórios e salas de aula, a existência de pólos descentralizados e outras estratégias.

\section{- Sistema de tutoria: Cursos a Distância têm professores sim!}

É engano considerar que programas a distância podem dispensar o trabalho e a mediação do professor. Nos Cursos a Distância, os professores vêem suas funções se expandir. Para Authier (1998), são "produtores quando fazem suas propostas de cursos; conselheiros, quando acompanham os alunos; parceiros, quando constroem com os especialistas em tecnologia novas abordagens de aprendizagem".

Em um programa a distância, portanto, eleva-se o nível de exigência dos recursos humanos envolvidos: além de professores-especialistas nas disciplinas, deve-se contar com tutores, avaliadores, especialistas em comunicação e no suporte de informação escolhido, entre outros.

A improvisação, infelizmente comum numa relação face a face, não pode acontecer num Curso a Distância: a definição dos objetivos, dos conteúdos, da bibliografia básica e complementar, a elaboração do material, a escolha da mídia, todos esses aspectos são 
definidos a priori e devem estar sob responsabilidade de profissionais altamente competentes, para garantir o alcance dos resultados educacionais e o custo-efetividade do programa. A responsabilidade desses profissionais é compartilhada. Assim sendo, uma política de integração de equipes e de educação permanente para esse grupo é absolutamente necessária. Também se faz necessário a presença de pessoal de apoio técnico-administrativo, responsável pelas matrículas, expedição de materiais, registro do histórico escolar, apoio com tecnologia (especialmente em cursos on-line) e outras questões técnico-administrativas também devem estar envolvidos no projeto.

É essencial que os docentes responsáveis pela elaboração dos materiais, pela tutoria, pela coordenação do curso tenham uma formação acadêmica consistente.

\section{- Sistema de Comunicação: a interação é fundamental}

Para permitir o contato entre o tutor e o aluno, deve haver espaço físico disponível, horários para atendimento personalizado, facilidade de contato por telefone, fax, e-mail, correio, teleconferência, fórum de debate em rede e outros. Biblioteca, laboratórios, computadores, vídeos e outros recursos, postos à disposição na sede ou pólos descentralizados, abrem ao aluno que pode freqüentar esses espaços oportunidades de maior aproveitamento.

Sempre que necessário, os Cursos a Distância devem prever momentos presenciais, cuja periodicidade e obrigatoriedade devem ser determinadas pela natureza do curso oferecido.

Facilitar a interação dos alunos entre si também deve ser uma preocupação da instituição que oferece o curso. Para isso, é necessário saber quais os recursos que permitem dialogar com o professor ou tutor.

\section{- Recursos educacionais}

Não basta ter experiência com cursos presenciais para assegurar a qualidade da EaD. A produção de material impresso, vídeos, programas televisivos, radiofônicos, teleconferências, páginas Web atende a uma outra lógica de concepção, de produção, de linguagem, de estudo e de controle de tempo.

$\mathrm{O}$ uso da tecnologia na $\mathrm{EaD}$ tem frequentemente repetido métodos ineficazes de instrução ao vivo. Por exemplo: quando uma tecnologia interativa como a teleconferência é utilizada para apresentação de palestras, nenhuma inovação foi apresentada. E é falha grave 
quando uma instituição considera que a presença virtual é o mesmo que presença real: normalmente o aluno corre o risco de não receber o apoio didático necessário.

Os materiais didáticos devem traduzir os objetivos do curso, cobrir todos os conteúdos e levar aos resultados esperados, em termos de conhecimentos, habilidades, hábitos e atitudes. A relação teoria-prática deverá ser pano de fundo dos materiais, como estratégia de evitar a centralização que caracteriza Cursos a Distância. É aconselhável que indiquem o tempo médio de estudo exigido, a bibliografia básica e complementar e que forneçam elementos para o aluno refletir e avaliar-se durante o processo. Sua linguagem deve ser adequada e a apresentação gráfica deve atrair e motivar o aluno. No caso de serem utilizadas diferentes mídias, elas deverão estar articuladas.

\section{- Infra-estrutura de apoio}

Além de mobilizar recursos humanos e educacionais, um Curso a Distância exige a montagem de infra-estrutura material proporcional ao número de alunos, aos recursos tecnológicos envolvidos e à extensão de território a ser alcançada, o que representa um significativo investimento para a instituição.

É necessário ficar atento quanto: 1) à infra-estrutura material - equipamentos de televisão, videocassetes, fotografias, impressoras, linhas telefônicas, inclusive dedicadas para internet e serviços 0800, fax, equipamentos para produção audiovisual e para videoconferência, computadores ligados em rede e outros, dependendo da proposta do curso; 2) à possibilidade de dispor de centros de documentação e informação ou midiatecas (que articulam bibliotecas, videotecas, audiotecas, e infotecas; 3) aos locais de atividades práticas em laboratórios e os estágios supervisionados, inclusive para alunos fora da localidade, sempre que a natureza e currículo do curso exigir.

\section{- Sistema de avaliação contínuo e abrangente}

Mais que uma formalidade legal, a avaliação deve permitir ao aluno sentir-se seguro quanto aos resultados que vai alcançando ao longo do processo de ensino-aprendizagem. A avaliação do aluno feita pelo professor deve somar-se à auto-avaliação, que auxilia o estudante a tornar-se mais autônomo, responsável, crítico, capaz de desenvolver sua independência intelectual.

Por seu caráter diferenciado e pelos desafios que enfrentam, Cursos a Distância devem ser acompanhados e avaliados em todos os seus aspectos, de forma sistemática. Assim, devese desenhar um processo contínuo de avaliação quanto: às práticas educacionais dos 
professores; ao material; ao currículo; ao sistema de orientação docente ou tutoria; à infraestrutura material que dá suporte tecnológico, científico e instrumental ao curso e quanto à própria avaliação.

\section{- Ética na informação, publicidade e marketing}

A instituição que oferece o curso deve informar previamente: documentos legais que autorizam o funcionamento do curso; direitos que o curso confere; pré-requisitos exigidos; objetivos e conteúdos; preço e condições de pagamento; custos que os alunos deverão assumir durante o programa (tais como deslocamentos para participação em momentos presenciais, provas, estágios, etc.); profissionais responsáveis pelo desenvolvimento do curso; equipamentos, bibliografia, videoteca, software e outros recursos que estarão disponíveis aos alunos; local e horários de atendimento personalizado; meios de comunicação oferecidos para contato com o tutor; o tempo limite para completar os estudos e condições para interrompêlos temporariamente.

Os cursos de atualização, aperfeiçoamento, educação aberta em geral, que não conferem direito a créditos em outros cursos nem a exercício profissional, precisam deixar claro, desde a publicidade, seus propósitos, de forma a não gerar falsas expectativas.

\section{- Manutenção do curso}

$\mathrm{O}$ investimento em $\mathrm{EaD}$ - profissionais, materiais educacionais, equipamentos, tempo, conhecimento, sistemas de gestão e operacionalização dos cursos - é alto e deve ser cuidadosamente planejado e projetado de modo que um curso não tenha que ser interrompido antes de finalizado, prejudicando a instituição e, principalmente, os estudantes. Antes de matricular-se, o aluno deve informar-se sobre a solidez da instituição que oferece o curso.

Estudar à distância exige perseverança, autonomia, capacidade de organizar o próprio tempo, habilidade de leitura, escrita e interpretação (mesmo pela internet) e, cada vez mais freqüente, domínio de tecnologia.

Para Neves (2007), um Curso a Distância de qualidade para formação de professores busca concretizar as orientações da moderna pedagogia e visa formar sujeitos que sejam mais ativos, além de cidadãos comprometidos, pessoas autônomas, independentes, capazes de buscar, de criar, de aprender ao longo de toda a vida e de intervir no mundo em que vivem. 


\section{CAPÍtUlO 3 - CENTRO DE EDUCAÇÃO CONTINUADA EM EDUCAÇÃo MATEMÁTICA, CIENTÍFICA E AMBIENTAL - CECEMCA}

A Secretária de Educação Infantil e Fundamental do Ministério da Educação $(\mathrm{SEIF} / \mathrm{MEC})^{9}$, visando a melhora na qualidade de ensino abriu inscrições para universidades brasileiras enviarem propostas para a construção de Centros de Formação Continuada, Desenvolvimento de Tecnologia e Prestação de Serviços para a rede publica de ensino. Por meio do EDITAL Nº 01/2003, o MEC selecionou, no início de 2004, para financiamento em convênios, com duração de quatro anos, 20 (vinte) projetos de Centros de Formação Continuada de Professores de Educação Básica, propostos por Universidades Brasileiras (BRASIL, 2005b).

Os Centros de Educação Continuada são responsáveis pela construção da REDE NACIONAL DE FORMAÇÃO CONTINUADA (REDE)

“[...] estes Centros, articulados entre si e com outras IES (Instituição de Ensino Superior) produzirão materiais instrucionais e orientação para cursos a distância, semi-presenciais, atuando em rede para atender as necessidades e demandas dos sistemas de ensino." (BRASIL, 2005b. p.22.).

A dinâmica de interação é que vai concretizar uma trama de conhecimento, capaz de atingir todas as regiões e em diferentes áreas, uma vez que abrange cinco especialidades, entendidas como combinação de áreas de conhecimentos que integra o currículo da educação infantil e fundamental, conforme a tabela descrita a seguir (Tabela 2) (BRASIL, 2005b).

Tabela 2 - Número de Centros por Áreas de Especialidades

\begin{tabular}{|l|c|}
\hline Área de Especialidade & $\mathbf{N}^{\mathbf{o}}$. de Centros \\
\hline Alfabetização e Linguagem & 6 \\
\hline Educação Matemática e Cientifica & 5 \\
\hline Ensino de Ciências Humanas e Sociais & 3 \\
\hline Artes e Educação Física & 3 \\
\hline Gestão e Avaliação da Educação & 3 \\
\hline Total & 20 \\
\hline
\end{tabular}

Fonte: BRASIL, 2003

Organizado pelo autor

\footnotetext{
${ }^{9}$ Secretaria de Educação Infantil e Fundamental (SEIF) é a denominação antiga para a atual Secretaria de Educação Básica (BRASIL, 2007).
} 
As universidades que atualmente compõem a Rede Nacional de Formação Continuada estão distribuídas, dentro do território nacional, conforme a Figura 1.

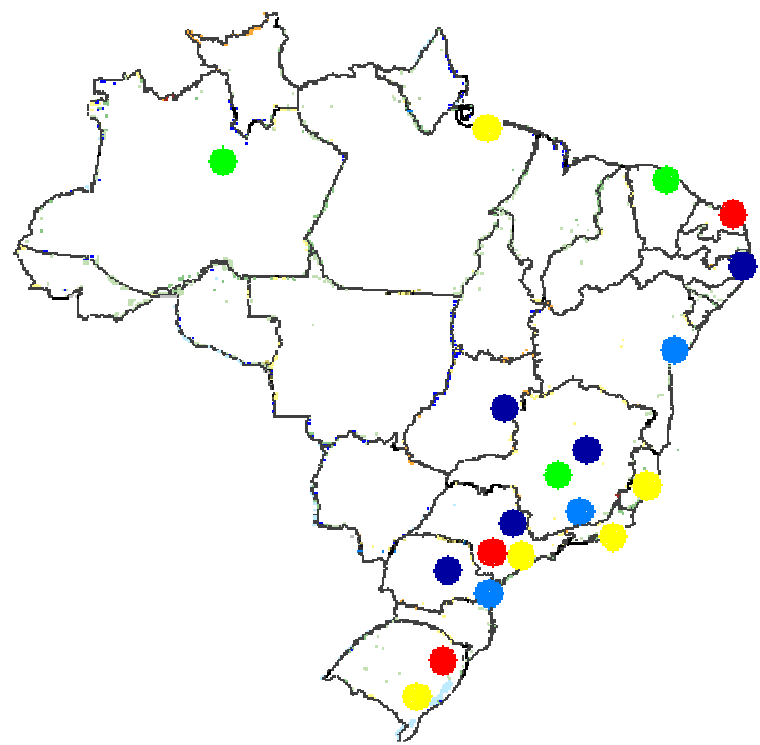

- Alfabetização e Linguagem

- Educação Matemática e Científica

- Ensino de Ciências Humanas e Sociais

- Artes e Educação Física

- Gestão e Avaliação da Educação

Figura 1 - Mapa da distribuição dos Centros da Rede de Formação Continuada, segundo áreas de especialidades.

Fonte: CECEMCA (2005).

A área de especialidade cabe a cada universidade (Tabela 3)

Tabela 3 - Rede Nacional de Formação Continuada, segundo as universidades que compõem cada área de especialidade.

\begin{tabular}{|c|c|}
\hline Área de Especialidade & Universidade \\
\hline Alfabetização e Linguagem & $\begin{array}{l}\text { - Universidade Federal de Pernambuco (UFPE) } \\
\text { - Universidade Federal de Minas Gerais (UFMG) } \\
\text { - Universidade Estadual de Ponta Grossa (UEPG) } \\
\text { - Universidade de Brasília (UNB) } \\
\text { - Universidade Estadual de Campinas (UNICAMP) }\end{array}$ \\
\hline Educação Matemática e Científica & $\begin{array}{l}\text { - Universidade Federal do Pará (UFPA) } \\
\text { - Universidade Federal do Rio de Janeiro (UFRJ) } \\
\text { - Universidade Federal do Espírito Santo (UFES) } \\
\text { - Universidade Estadual Paulista (UNESP) } \\
\text { - Universidade do Vale do Rio dos Sinos (UNISINOS) }\end{array}$ \\
\hline $\begin{array}{l}\text { Ensino de Ciências Humanas e } \\
\text { Sociais }\end{array}$ & $\begin{array}{l}\text { - Universidade Federal do Amazonas (UFAM) } \\
\text { - Universidade Federal do Ceará (UFC) } \\
\text { - Universidade Federal de Minas Gerais (UFMG) } \\
\text { - Pontifícia Universidade Católica de Minas Gerais } \\
\text { (PUC/MG) }\end{array}$ \\
\hline Arte e Educação Física & $\begin{array}{l}\text { - Universidade Federal do Rio Grande do Norte (UFRN) } \\
\text { - Pontifícia Universidade Católica de São Paulo (PUC/SP) } \\
\text { - Universidade Federal do Rio Grande do Sul (UFRS) }\end{array}$ \\
\hline Gestão e Avaliação da Educação & $\begin{array}{l}\text { - Universidade Federal da Bahia (UFBA) } \\
\text { - Universidade Federal de Juiz de Fora (UFJF) }\end{array}$ \\
\hline
\end{tabular}


Fonte: (BRASIL, 2006. p.27-28.)

Organizado pelo autor

- Universidade Federal do Paraná (UFPR)

\section{1 - CECEMCA - Estrutura e Organização}

A Universidade Estadual Paulista "Julio de Mesquita Filho", campus de Rio Claro, em parceria com o campus de Bauru, teve o projeto na área de Educação Matemática, Científica e Ambiental aprovado pelo Ministério da Educação para implantar seu Centro, integrando-se à Rede de Formação Continuada com o Centro de Educação Continuada em Educação Matemática Científica e Ambiental - CECEMCA.

O CECEMCA destina-se a ações de formação para professores da rede pública do ensino, nas áreas: matemática, cientifica e meio ambiente.

Embora o CECEMCA tivesse estruturado suas atividades em fevereiro de 2004, o convênio entre o MEC e a UNESP foi oficialmente formalizado em julho do mesmo ano, iniciando o trabalho, com o financiamento do Fundo Nacional de Desenvolvimento da Educação (FNDE) em outubro de 2004.

O Centro de Educação Continuada em Educação Matemática, Científica e Ambiental (CECEMCA-UNESP) é um dos centros da Rede, e responde por ações dirigidas à formação continuada de professores nas áreas de Educação Matemática, Científica, Ambiental. Participam do CECEMCA especialistas (pesquisadores, professores, pós-graduandos e alunos de graduação) da Universidade Estadual Paulista (UNESP). O CECEMCA esta diretamente vinculada à Reitoria da Unesp e possui dois núcleos, o núcleo de Bauru e o núcleo Rio Claro.

Com uma proposta diferenciada da estrutura clássica de cursos de formação continuada, o CECEMCA está estruturado segundo os objetivos e a estrutura da Rede, publicada no item 1.9 (tabela 2) do EDITAL 01/2003 - SEIF/MEC. Objetivando quatro pontos:

1) Desenvolver programas e Cursos de Formação Continuada de professores para educação infantil e fundamental, podendo ser desenvolvido em três modalidades: Presencial, Semi-Presencial e a Distância, incluindo o material didático, desenvolvido pelo Centro, no caso são ao todo 15 cadernos $^{10}$ (cujo conteúdo será detalhado adiante), para essas formações (livros, vídeos, softwares).

\footnotetext{
${ }^{10}$ Sendo 8 do núcleo Bauru e 7 do núcleo Rio Claro
} 
2) Desenvolver projetos de formação de tutores (professores-coordenadores), profissional da área de formação. O papel do tutor é fundamental, pois é o encarregado da organização e da coordenação dos grupos de estudos. Também é importante a orientação do Centro para que o tutor desenvolva seu papel.

3) Desenvolver tecnologias educacionais.

4) Associação a programas de parcerias e convênios com as IES que oferecem formação continuada para que haja implantação de novas tecnologias, trocas de experiências, enfim a consolidação de uma Rede (BRASIL, 2003).

O Núcleo de Educação Cientifica e Matemática Bauru atua na Formação Continuada de Professores da Educação Infantil e de $1^{\mathrm{a}}$ a $4^{\mathrm{a}}$ série do ensino fundamental, adotando os temas transversais Ciências, Tecnologia, Sociedade e Ambiente (CTSA).

No presente trabalho serão analisadas ações trabalhadas pelo núcleo de Rio Claro, que se estruturou na proposta de interagir aspectos de Educação Cientifica e Matemática, tendo como tema o transversal a Educação Ambiental, sempre considerando o currículo escolar do Ensino Fundamental. A Educação a Distancia /EaD, trabalha de forma integrada com ambos os núcleos. A organização do CECEMCA acontece a partir de um coordenador como mostra a figura 2

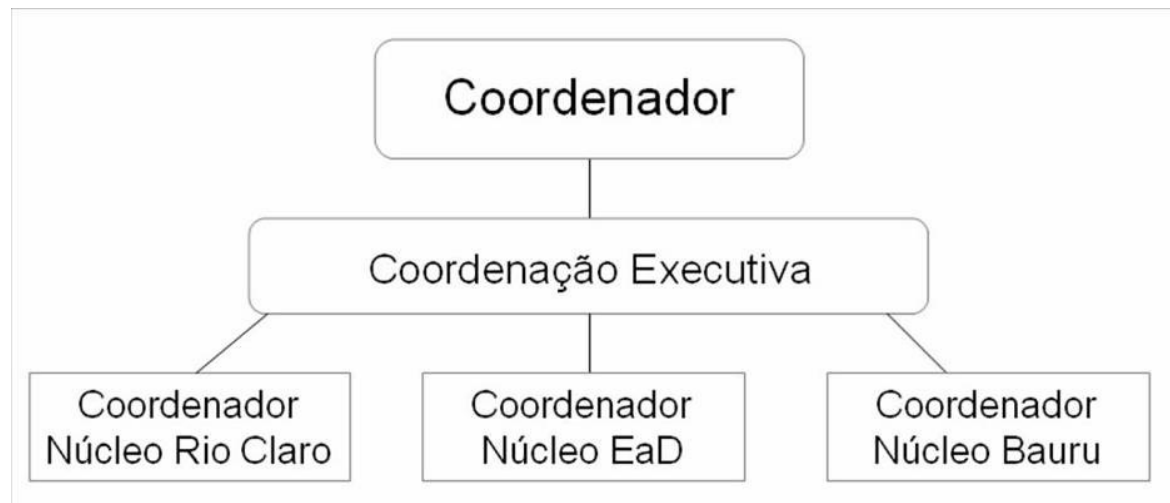

Figura 2: Organograma da administração do CECEMCA

Fonte: CECEMCA (2005).

Organizado pelo autor. 
O Núcleo de Educação Ambiental, Científica e Matemática (Rio Claro), atua na formação continuada de professores de $1^{\mathrm{a}}$ a $8^{\mathrm{a}}$ séries. A proposta é interagir aspectos de Educação Científica e Matemática, tendo como tema transversal a Educação Ambiental. Ao mesmo tempo considera as disciplinas escolares como meios essenciais para o desenvolvimento de tais práticas.

O Núcleo está ligado à unidade complementar Centro de Estudos Ambientais (CEA) e a unidades auxiliar: Centro de Análise e Planejamento Ambiental (CEAPLA) da UNESP de Rio Claro.

\section{2 - Produtos CECEMCA - Núcleo Rio Claro}

Segundo CECEMCA (2005), o Centro elaborou os seguintes produtos: oficinas pedagógicas de 4 horas de duração para Formação continuada de professores da Educação Básica abordando a temática científica e ambiental; cursos de variada carga horária, compreendendo Especialização e Extensão Universitária; serviços de assessoria a Redes de Ensino, em ações de formação e desenvolvimento de infra-estrutura e Cadernos de Formação que apresentam textos e propostas de atividades dentro da mesma temática, destinados à professores do Ensino Fundamental ( $1^{\mathrm{a}}$ à $4^{\mathrm{a}}$ série).

Os cadernos elaborados pelo CECEMCA são os seguintes: Cartografia e Meio Ambiente; Consumo Sustentável / Consumo Responsável - Desenvolvimento, Cidadania e Meio Ambiente; Conhecimento Indígena e Respeito à Natureza; Fauna e Parques Brasileiros; A Entomologia e a Óptica Aplicadas a Educação Ambiental; A Terra em que Vivemos e o caderno Áreas Verdes.

Segundo CECEMCA (2005), o Caderno de Cartografia e Meio Ambiente apresenta assuntos como: Representação cartográfica; Cartografia temática; Sensoriamento remoto do meio ambiente; Percepção ambiental.

O Caderno Consumo Sustentável / Consumo Responsável - Desenvolvimento, Cidadania e Meio Ambiente diz respeita à Sociedade de consumo atual; Danos ambientais do consumo; Novos rumos em direção ao consumo sustentável e A problemática dos resíduos sólidos.

O Caderno O Conhecimento Indígena e Respeito à Natureza - Bases para a Educação Ambiental, apresenta temas como a Herança Indígena na Cultura Caiçara; Representações do Espaço; Mitos e Equilíbrio Ecológico; Práticas Econômicas e Respeito à Natureza. 
O Caderno Fauna e Parques Brasileiros aborda assuntos relacionados aos Problemas enfrentados para a conservação da fauna, tais como: perda de habitat, fragmentação, caça, espécies exóticas e invasoras. Também a aborda a relevância das Unidades de conservação, e trabalha temas como: criação em cativeiro e manejo de fauna.

O Caderno A Entomologia e a Óptica Aplicadas a Educação Ambiental traz temas como: Comunicação entre espécies; Metamorfose; Óptica e natureza; Insetos; Cadeia alimentar; Desequilíbrio ambiental; Nichos culturais e sociais; Entomologia e Óptica.

O Caderno A Terra em que Vivemos apresenta assuntos relativos a Materiais inovadores de uso cotidiano; Água e o uso sustentável; Som, comunicação e poluição sonora; Luz, cores e biosfera; Ar e Eletricidade, magnetismo e geração de energia.

O Caderno Áreas Verdes traz assuntos como: Áreas verdes - caracterização e importância; Vegetação, biomas brasileiros e áreas de reflorestamento; Agenda 21 Escolar. 


\section{CAPITULO 4 - “ÁREAS VERDES": UMA PROPOSTA A SER DESENVOLVIDA JUNTO A PROFESSORES DAS REDES PÚBLICAS DE ENSINO}

\section{1 - Considerações sobre o Caderno "Áreas Verdes"}

O tema "Áreas Verdes" foi preparado para professores do Ensino Fundamental e tem seus objetos estabelecidos nos Parâmetros Curriculares Nacionais - PCN, através dos temas transversais.

Acompanha este caderno uma publicação de Educação Matemática que trabalha as questões conceituais e práticas da Matemática, tendo como referência aspectos relacionados às Áreas Verdes.

O primeiro capítulo aborda o surgimento e distribuição atual da vegetação no planeta, e mostra que o processo de devastação é muito rápido, tornando as áreas vegetadas cada vez mais escassas em muitos continentes.

O segundo capítulo "Considerações sobre a Vegetação Brasileira", apresenta a riqueza da vegetação brasileira, associada à grande extensão territorial e as grandes diversidades morfoclimáticas. O processo de degradação é avaliado indicando a necessidade de se criar uma consciência ambiental, colaborando para o desenvolvimento da cidadania.

O terceiro capítulo "Agricultura e Meio Ambiente" aborda as diversas etapas da agricultura no Brasil, e também, o processo de devastação da vegetação natural. $\mathrm{O}$ reflorestamento é tratado como maneira compensatória à supressão da vegetação nativa de um determinado local.

No quarto capítulo "Manutenção e Conservação das Áreas Verdes" é destacada a necessidade de preservação de conservação dos ecossistemas brasileiros e são apresentadas as principais Unidades de Conservação Brasileira.

No quinto capítulo "A Urbanização e as Áreas Verdes” trata dos aspectos da função ecológica relativo ao ciclo hidrológico. Também neste capítulo, destacam-se as funções social e educativa das áreas verdes, e mostra a questão da transversalidade, onde as áreas verdes e a educação ambiental permitem a inclusão social no âmbito educacional e no cotidiano do aluno. Também são tratados aspectos da função econômica e paisagística no meio urbano.

O sexto capítulo "Caracterização das Áreas Verdes Urbanas" aborda a composição da cobertura vegetal e sua influência no meio.

O sétimo capítulo “A necessidade da Valorização das Áreas Verdes nas Cidades” trata da necessidade de preservação das áreas verdes para o bem estar das populações. 
O oitavo capítulo "Agenda Verde Escolar" ressalta a importância de um trabalho ambiental no âmbito escolar e oferece sugestões para se elaborar um projeto visando a relação escola e comunidade.

O capítulo nove apresenta um "Roteiro de Análise Ambiental para Trabalho de Campo".

O objetivo deste caderno é, a partir dos conceitos trabalhados e desenvolvidos, proporcionar uma análise reflexiva sobre o tema "Áreas Verdes" por meio da discussão da espacialidade de maneira multiescalar no cotidiano da escola. A finalidade desse material é fazer com que o professor, ao praticar sua interdisciplinaridade, consiga compreender os temas nas diferentes áreas do conhecimento.

\section{2 - Caracterização e importância das áreas verdes}

Os problemas que as cidades enfrentam a partir de um determinado estágio de crescimento são bem conhecidos, como o déficit habitacional, a poluição do ar, das águas e visual, carência de infra-estrutura básica, dificuldades de locomoção, e conseqüentemente, diminuição da qualidade de vida dos os habitantes. Assim, crescem com as cidades os problemas sócio-econômicos e o desequilíbrio ambiental.

"O capitalismo em versão brasileira (desenvolvimentismo) gerou uma quantidade incalculável de problemas para as cidades" (SANTOS, 1983, p.39). Trouxe multidões de migrantes demandando habitação, infra-estrutura, serviços e empregos e, conseqüentemente, estas demandas recaíram sobre o poder local, que, na maioria das vezes, não pode atender a todas no tempo necessário. Desse modo, nas cidades brasileiras é impossível discutir a sustentabilidade urbana sem minimizar os níveis de pobreza, universalizar os serviços de infra-estrutura, saúde e educação, reduzir o uso ilegal do solo (ocupação de áreas de risco) e a violência urbana, bem como, combater a poluição e degradação ambiental, recuperar, proteger e conservar o patrimônio histórico e ambiental. Evidentemente, tais soluções dependem de adequação do atual modelo econômico, de forma a assegurar os recursos financeiros necessários.

A sustentabilidade das cidades depende, segundo Buarque (1994), da nossa capacidade de reorganizar os nossos espaços, gerir novas formas de desenvolvimento, melhorar a qualidade de vida e superar as desigualdades sócio-econômicas, como condição para o crescimento econômico. A cidade sustentável é uma construção coletiva. Do ponto de vista do homem, uma sociedade é sustentável quando é capaz de satisfazer às necessidades do ser 
humano, sem comprometer as perspectivas das gerações futuras. A sustentabilidade enfatiza a durabilidade e a permanência, um futuro garantido para um número razoável de seres humanos (CALLENBACH, 2001).

Como o mundo urbano não é homogêneo, há uma multiplicidade de atos, modos de vida, de relações e, também, as diferenças entre cidades (CARLOS, 1992). E nesse espaço que constitue a paisagem urbana, surgem elementos que dão forma, relevo, características, são espaços de vida, seja ela pública ou privada. "Principalmente porque o espaço não é só cavidade vazia 'negação de solidez': é vivo e positivo. Não é apenas um fato visível: é, em todos os sentidos, e, sobretudo num sentido humano e integrado uma realidade vivida" (ZEVI, 1978, p.145).

O espaço urbano, sob seu aspecto físico, é geralmente considerado como um conjunto composto de espaços edificados, com áreas ocupadas predominantemente por edificações, e de espaços livres, ambos resultantes das ações humanas institucionalizadas ou não (SÁ CARNEIRO; MESQUITA; 2000).

Assim, espaços livres e áreas verdes podem exercer um importante papel na identidade dos lugares, muitas vezes ressaltando as características físicas do sitio, ou atuando como limites de áreas urbanizadas.

Tem sido muito comum a não distinção entre os termos espaços livres e áreas verdes e também se associa a essas áreas, o uso exclusivo e imediato para o lazer. Mas Bartalini (1986) considera que os espaços livres e as áreas verdes desempenham no urbano três funções, que podem ser agrupadas em três conjuntos: visuais ou paisagísticos, recreativos (sociais) e ambientais, sendo ideal que estas funções estejam interligadas.

A qualidade do ambiente urbano está relacionada aos aspectos físicos, psicológicos e visuais da paisagem. Sendo assim, é fundamental para a cidade a presença de espaços livres contendo áreas verdes, pois a vegetação está intrinsecamente relacionada à melhoria e manutenção da qualidade ambiental urbana.

\section{3 - Benefícios da arborização urbana}

- Clima

A vegetação pode ser utilizada para interceptar a radiação solar, como aquela refletida pelo solo ou por superfícies de edificações próximas. Ela também desempenha importante papel no controle da umidade presente no ar, a qual contribui em importante fator de conforto térmico. Porém, nem sempre a vegetação pode ser favorável às condições de conforto térmico humano, porque o ambiente urbano é composto por um conjunto de estruturas, algumas 
naturais, outras resultantes da intervenção humana: parques, praças e rios, determinando uma grande diversidade climática (SATTLER, 1994).

Durante as horas de luz do dia, a radiação solar é absorvida pela superfície das cidades (asfalto, concreto, aço, vidro, telhado e outros), todas superfícies são isolantes térmicos parciais, pois ganham e perdem calor mais facilmente do que a vegetação, no solo. Árvores, arbustos e gramas amenizam a temperatura do ar em meio urbano, por controlar a radiação solar através da interceptação, reflexão e absorção pelas folhas das árvores (GREY; DENEKE, 1978).

De acordo com PAIVA e GONÇALVES (2002), o vegetal atuará na moderação climática, principalmente sobre três aspectos:

- intercepta os raios solares, criando áreas de sombreamento;

- reduz a temperatura ambiente, evitando a incidência solar direta no concreto e asfalto;

- umedece o ar devido à constante transpiração, eliminando água para o meio ambiente.

Segundo Lombardo (1990), as árvores e outros vegetais podem ser extremamente eficientes ao clima urbano, diminuindo as ilhas de calor da cidade, através da interceptação, reflexão e transmissão da radiação solar.

O fornecimento de sombras pelas árvores, além de diminuir a temperatura na cidade, através da sua evapotranspiração, também abranda as ilhas de calor nos dias quentes. A temperatura do ar, em cidades, pode ser maior em relação às áreas rurais, devido à localização do sol, vegetação com concreto, asfalto e metal (McPHERSOM, 1992).

O vento também afeta o conforto humano, por consequiência, no verão retira as moléculas de água transpiradas de homens e árvores, aumentando a evaporação e conforto térmico, enquanto que, no inverno, contribui ao resfriamento do ar (MILANO, DALCIN, 2000).

As árvores reduzem a velocidade dos ventos e podem interferir no processo de evaporação, através da obstrução, direção e filtração dos ventos, de acordo com a variação do tamanho das espécies, forma, folhagem (densidade e retenção) e localização das plantas. A combinação de árvores e arbustos, em fileiras, são sugeridas para obter uma adequada proteção, pois a quebra do vento depende das duas alturas e penetrabilidade (GREY, DENEKE, 1978).

\section{- Qualidade do ar}

As árvores urbanas melhoram diretamente a qualidade do ar por absorver gases poluentes (ozônio, óxido de nitrogênio) através da superfície das folhas, interceptação de 
materiais particulados (poeira, cinza, pólen e fumaça), liberação de oxigênio através da fotossíntese, transpiração da água e resfriamento da superfície, com redução da temperatura do ar local (McPHERSON; SIMPSON, 2002).

As árvores ajudam a melhorar a qualidade do ar pela presença da área de superfície foliar, na qual os particulados de poluentes podem ser atraídos e acumularem-se nos estômatos, sendo dissolvidos e liberados durante as trocas gasosas (NOWAK, McPHERSON, 1993). De acordo com Grey e Deneke (1978), as árvores grandes removem mais ozônio do que as árvores pequenas.

Considerando-se que as árvores podem controlar poluentes, e com isso apresentar potencial para melhorar o clima das cidades, propiciando economia de custos energéticos, são vistas como estratégia para restaurar a qualidade do ar e aumentar a saúde física e mental da população (DWYER et al., 1992).

A renovação das folhas, nas espécies caducifólias, também pode ser considerada um fator importante na redução da poluição atmosférica (SANTOS, 1994).

\section{- Hidrologia urbana}

A permeabilidade do solo constitui um dos principais estudos da hidrologia urbana, pois o aumento indiscriminado da impermeabilidade do solo contribui para o incremento do escoamento superficial e enchentes. Apesar dos planos diretores preverem a obrigação em deixar-se um percentual de área permeável, na realidade, isto não acontece. O principal obstáculo para a fiscalização da área permeável, é que não adianta fiscalizar apenas um determinado ponto, devendo ser observada a superfície de uma bacia (CENTENO et al, 2003).

\section{- Economia de energia}

As árvores grandes fornecem sombra para as construções residenciais, reduzindo os gastos com energia elétrica, principalmente nos meses de verão. Em lugares que possuem invernos rigorosos, é recomendado o plantio de espécies caducifólias, pois proporcionam maior incidência do sol nas residências. Evidentemente, devem-se considerar os fatores clima, tipo de espécie, tamanho da copa e altura das árvores. 


\section{- Estética e redução do barulho}

Para Mello Filho (1985), as árvores renovam a paisagem urbana, quebrando a monotonia e a frieza típica das construções, além de fornecer abrigo e alimento para a fauna da região.

A vegetação urbana contribui para a harmonia da paisagem, quebrando a dureza e a rigidez do concreto, criando linhas mais suaves e naturais (PAIVA, GONÇALVES, 2002).

A qualidade ambiental e paisagem dos imóveis são valorizadas economicamente (DETZEL, 1992) e a maioria das pessoas considera a estética como indicadora dessa valorização, em virtude da beleza das flores nas diferentes estações do ano (HARDER, 2002).

As questões estéticas relacionadas ao valor econômico do imóvel são difíceis de quantificar; contudo, alguns destes benefícios podem ser vistos em diferenças de preços, nas vendas de propriedades com árvores (McPHERSON, SIMPSON, 2002).

De acordo com Price (2003), os problemas de quantificação dos benefícios estéticos estão na escolha de variáveis adequadas, na forma de relação e na interação entre elas.

As pesquisas sobre árvores que atenuem o barulho, ainda são limitadas, pois uma ou poucas árvores espalhadas não reduzirão significativamente o barulho, porém, o conjunto de várias delas pode ser efetivo (GREY, DENEKE, 1978).

A vegetação pode diminuir os ruídos, não havendo, no entanto, uma opinião formada definitiva sobre o assunto; o que se tem notado é que os elementos introduzidos entre a fonte e o receptor reduzem o som por absorção, deflexão, reflexão e difração (PAIVA, GONÇALVES, 2002). 


\section{CAPÍTULO 5 - APLICAÇÃO DO CURSO DE ÁREAS VERDES NO MUNICÍPIO DE} ALFENAS

\subsection{A realidade local}

O município de Alfenas se localiza no Estado de Minas Gerais, a $340 \mathrm{~km}$ da capital Belo Horizonte. De acordo com a contagem do Instituto Brasileiro de Geografia e Estatística (IBGE) (BRASIL, 2009) sua população é de 71.628 habitantes e possui área territorial de 848 $\mathrm{km}^{2}$ (Figura 3).

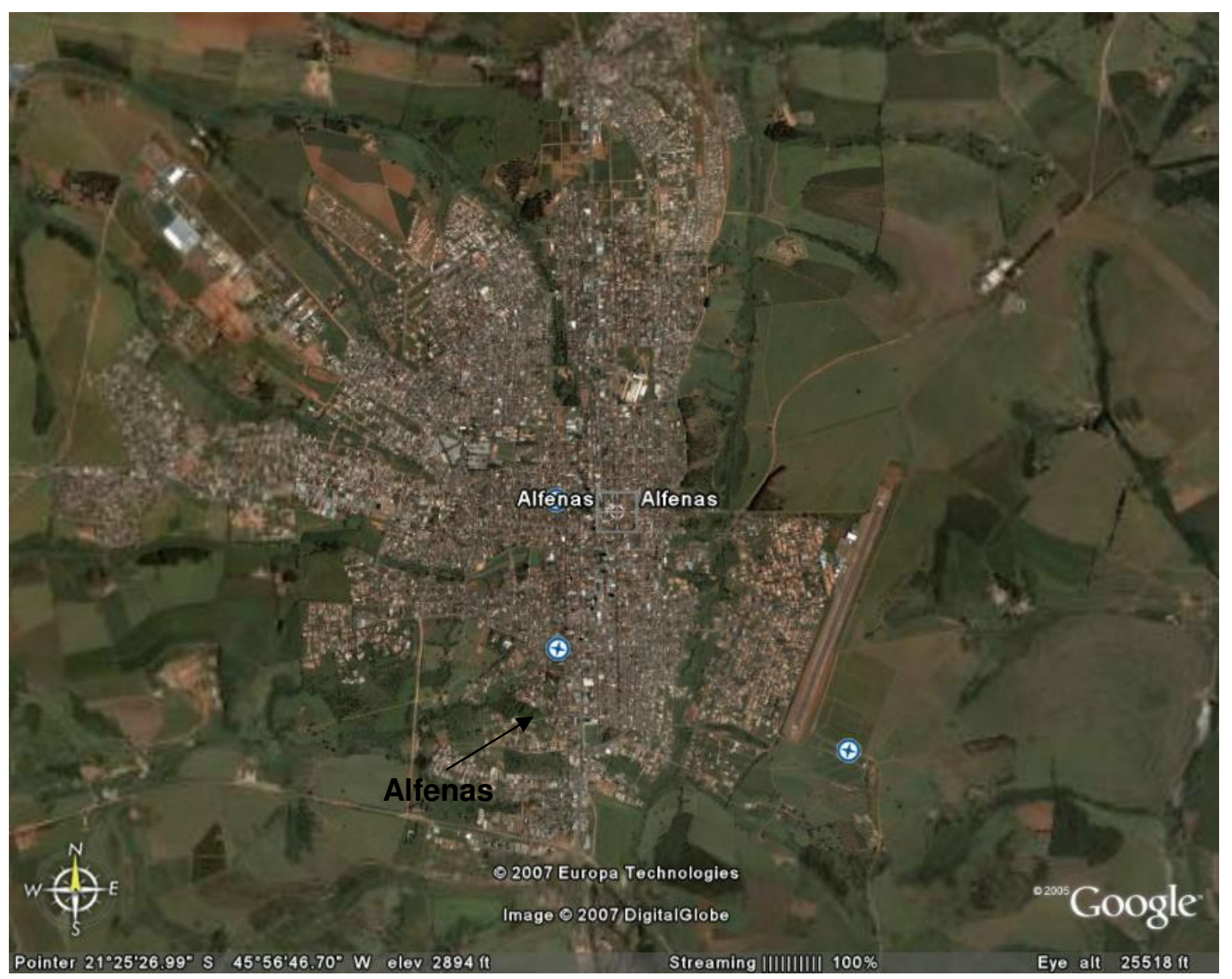

Figura 3 - Imagem do município de Alfenas-MG.

Fonte: Google Earth.

O clima da região é do tipo tropical com influência da altitude de aproximadamente $880 \mathrm{~m}$. A morfologia predominante no município é de relevo ondulado, composto por rochas cristalinas. 
O inverno no município dura de 2 a 4 meses secos e déficit hídrico pequeno, entre 10 a $30 \mathrm{~mm}$, sendo o seu regime de captações médias entre 1.400 a $1.700 \mathrm{~mm}$ e o seu regime de distribuição periódica predominando no período mais quente do ano (HASUI; RAMOS; SILVA, 2009)

A vegetação predominante é o Cerrado e Floresta do tipo Estacional Semidecídua.

O município é circundado pelo Lago de Furnas (Figura 4) que é a maior extensão de água do Estado de Minas Gerais e Alfenas é um dos 34 municípios que compõe o circuito dos lagos da Represa de Furnas (HASUI; RAMOS; SILVA, 2009).

O Lago de Furnas transformou a paisagem do município de Alfenas e atraiu turistas, principalmente, da região. De acordo com a Associação dos Municípios do Lago de Furnas ALAGO (Associação dos municípios do Lago de Furnas, 2009):

[...] historicamente a região guarda a memória das tribos indígenas que ali habitaram, das trilhas bandeirantes em busca de ouro, das fazendas seculares e dos quilombos rebeldes. Muito dessa história submergiu em fevereiro de 1963, quando as águas do lago subiram seu nível por sobre casas, plantações e até mesmo cidades, transformando definitivamente o lugar. Seus habitantes levaram algum tempo para reconhecer a nova paisagem e as novas possibilidades oferecidas pelo grande lago que se formara. Aos poucos, porém, em seus remansos, agradáveis pousadas, férteis pesqueiros e elegantes embarcações foram surgindo e delineando o futuro turístico do Lago de Furnas. 


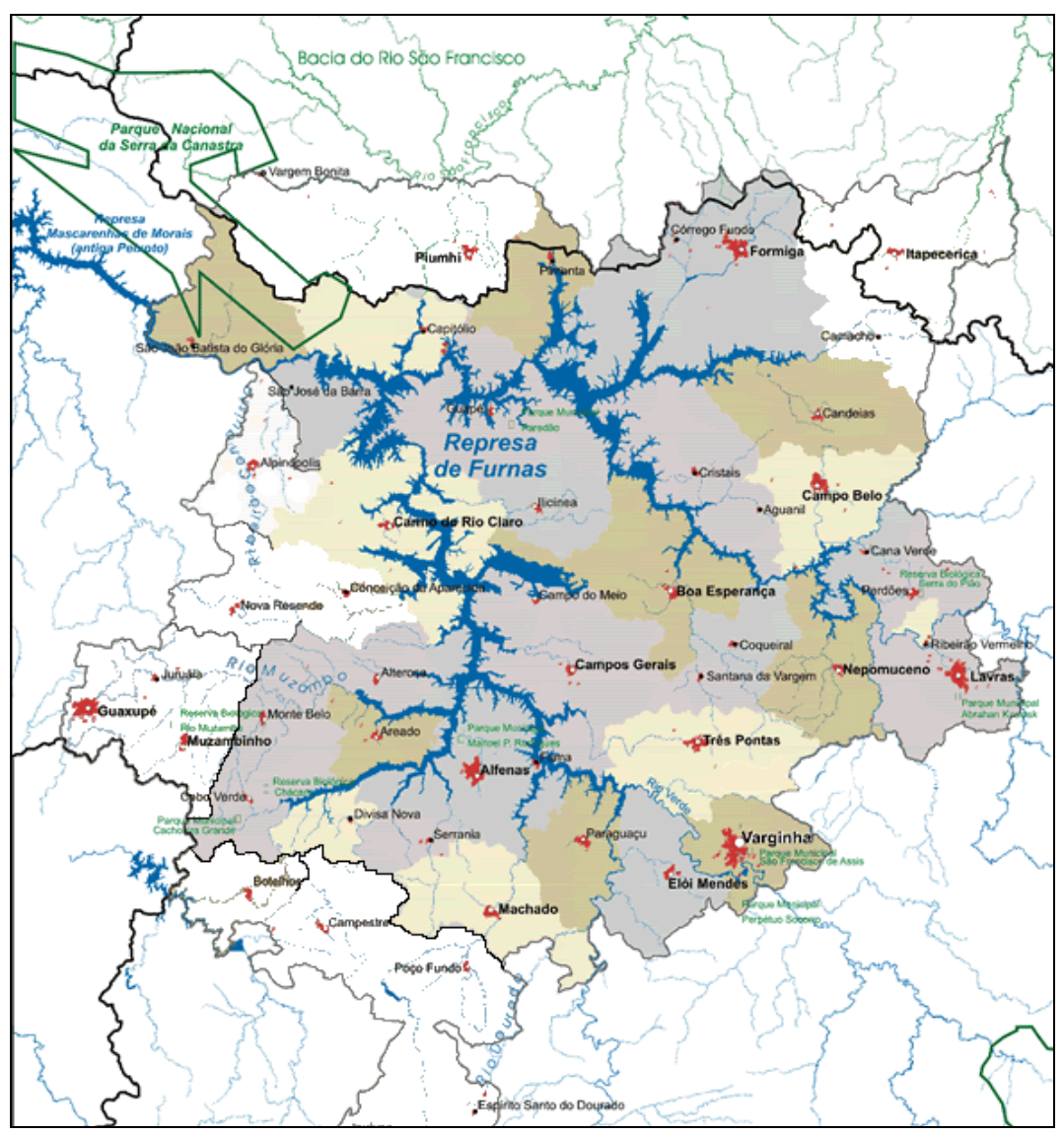

Figura 4 - Representação do Lago de Furnas no município de Alfenas

\subsection{O curso de Áreas Verdes}

O projeto em questão é fruto da parceria firmada entre a Prefeitura Municipal de Alfenas - MG e a UNESP - Campus de Rio Claro, oferecido pelo CECEMCA. Teve como objetivo a realização de um curso de Formação Continuada em Educação Ambiental para professores da Rede Municipal de Ensino, tendo como temática o caderno em questão Áreas Verdes (CECEMCA, 2007).

O curso foi elaborado para a formação de tutores que exerceram o papel de multiplicadores, denominados aqui como professores-coordenadores, que receberam formação prévia para trabalhar com o conteúdo de Áreas Verdes, propiciando subsídios para formação e organização dos grupos de estudos com professores da Educação Infantil; Educação Básica nível I e Educação Básica nível II ( $1^{\mathrm{a}}$ a $8^{\mathrm{a}}$ do ensino fundamental) tanto da área urbana como da área rural. A formação dos professores foi concentrada em atividades presenciais e atividades à distância $(\mathrm{EaD})$ junto à equipe formadora do CECEMCA (LOMBARDO, LOURENÇO E VOLPE, 2007). 
O curso completo teve a participação de 431 professores divididos em grupos de estudos (professores-alunos) coordenados por 33 professores (professores-coordenadores). $\mathrm{O}$ curso apresenta dois momentos: um curso de formação para 33 professores-coordenadores de 108 horas; e um curso de formação para 431 professores-alunos de 80 horas. No primeiro momento, a equipe de formadores do CECEMCA ministrou um curso presencial para os professores-coordenadores fornecendo subsídios para que estes, no segundo momento, coordenassem presencialmente grupos de estudos formados por professores-alunos. O curso semi-presencial, formado pelos módulos presencial e a distância ministrado pela equipe do CECEMCA, teve o objetivo de formar os professores-coordenadores. O curso totalmente presencial ministrado pelos professores-coordenadores teve o objetivo de formar os professores-alunos.

O eixo pedagógico central é subsidiado pela formação colaborativa, através da leitura do caderno, oficinas, palestras, trabalhos de campo e discussões no grupo que permitiram espaço para o surgimento de dúvidas, elaboração e "reelaboração" de atividades aplicadas pelos professores em sua prática na sala de aula (CECEMCA, 2007).

Os grupos de estudos foram orientados e formados presencialmente durante 40 horas com a realização de atividades presenciais entre oficinas e discussões visando à obtenção de subsídios para a discussão da prática de ensino dos professores e atualização de conhecimentos referentes ao conteúdo apresentado.

\subsection{0 curso presencial}

O curso presencial foi concentrado, sendo trabalhado em sala de aula parte do conteúdo do caderno “Áreas Verdes” por meio de palestras, oficinas e trabalho de campo, e contou com a coordenação da Profa. Dra. Magda Adelaide Lombardo e a participação dos formadores do CECEMCA Larissa Lucciane Volpe e Jeferson M. R. M. F. Lourenço.

O conteúdo programático no curso presencial dividiu-se em:

1. Biomas/Ecossistema/Vegetação;

2. Áreas verdes e mudanças climáticas;

3. Áreas verdes urbanas;

4. Impactos ambientais;

5. Trabalhos de campo;

6. Oficinas;

7. Registros;

8. Ferramentas de EaD. 
O conteúdo foi trabalhado por meio de aulas teóricas (Fotos 1 e 2), elaboração de oficinas (Foto 3), discussões em grupo (Foto 4) e trabalho de campo (Foto 5) que possibilitaram aos professores ter uma visão mais abrangente do conteúdo do caderno. Como foi o objetivo, durante as atividades, muitos professores-coordenadores elaboraram suas próprias oficinas e atividades para aplicação com grupos de estudos, sendo estimulada a criação de atividades com momentos de reflexões sobre o tema. Também foi utilizado um filme, parte do material do curso presencial, intitulado "O que foi", que apresenta os módulos dos cadernos do CECEMCA por meio de uma representação. O filme inicial despertou o interesse dos professores-coordenadores pelo conteúdo dos cadernos e permite a reflexão dos temas abordados.

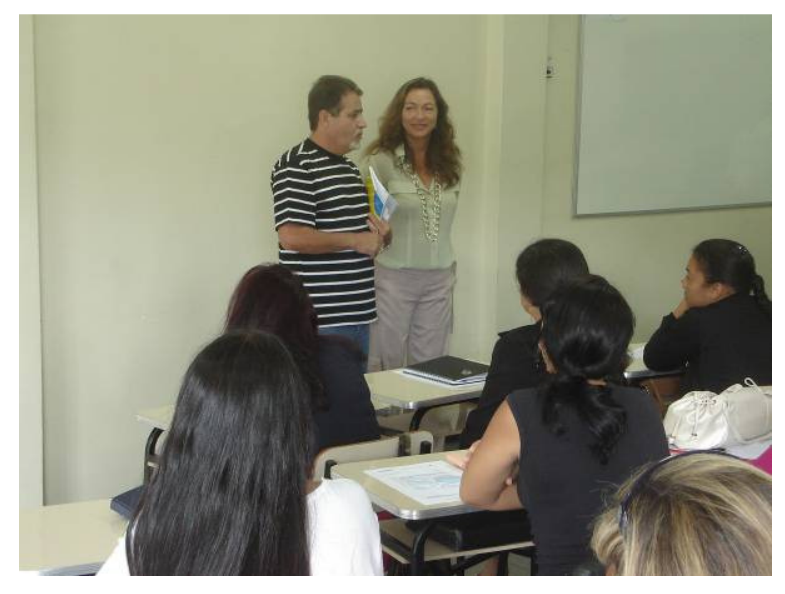

Foto 1: Apresentação do Cecemca Rio Claro

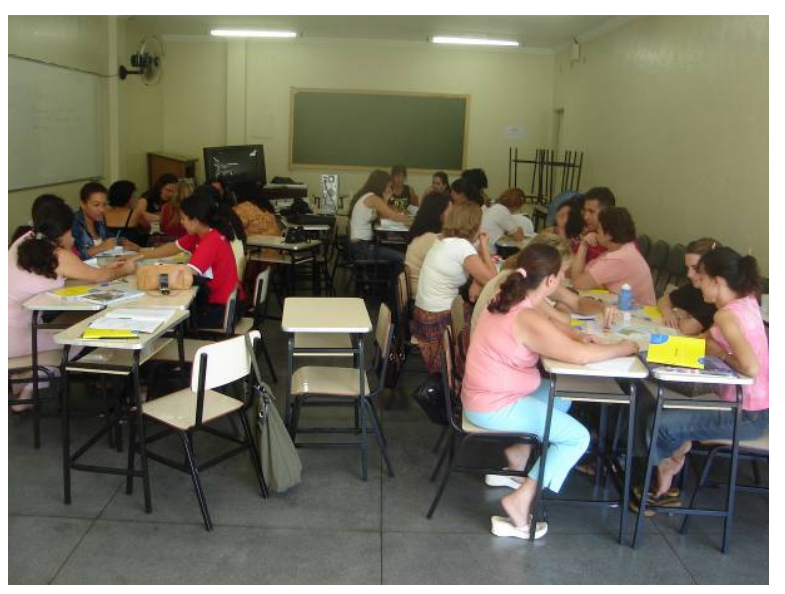

Foto 3: Oficina

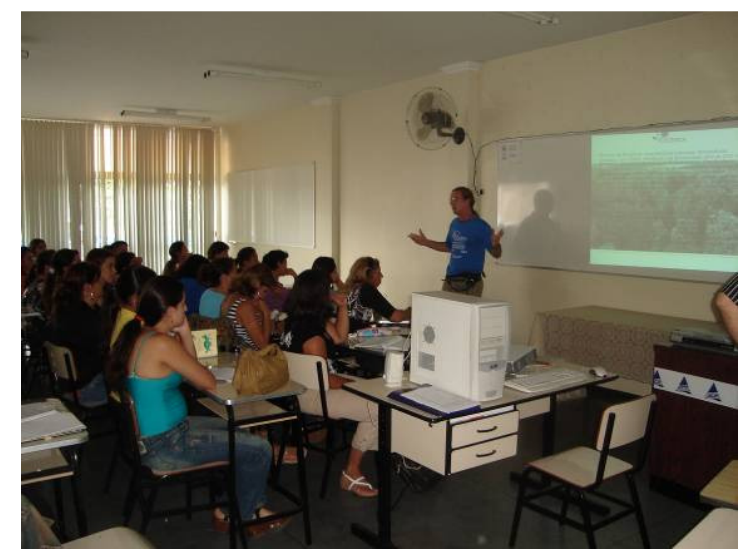

Foto 2: Aulas teóricas: vegetação brasileira

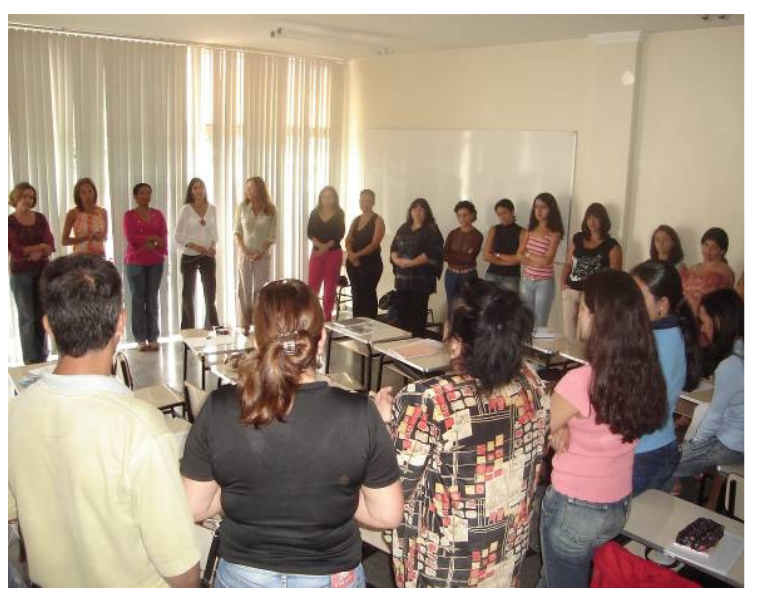

Foto 4: Dinâmica em grupo

Fotos: Larissa Volpe e Jeferson M R M F Lourenço (2007) 


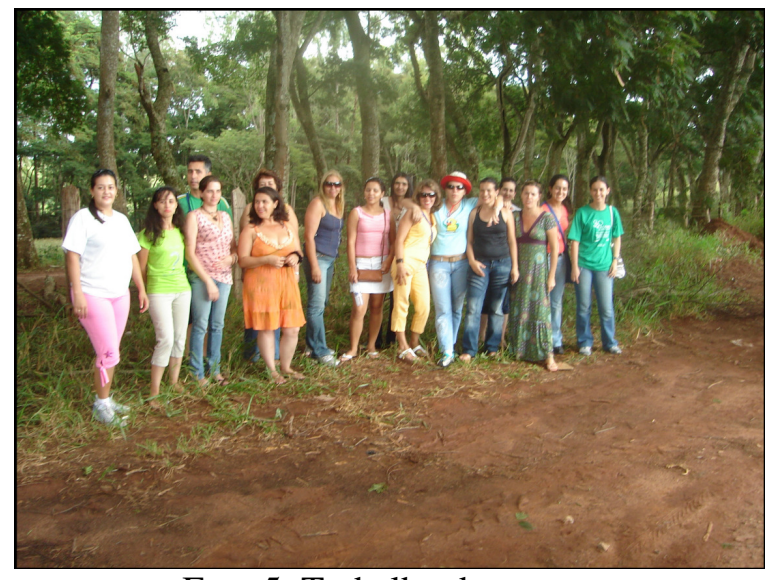

Foto 5: Trabalho de campo

Fotos: Magda Adelaide Lombardo e Jéferson M R M F Lourenço (2007)

O conteúdo do caderno "Áreas Verdes" foi trabalhado com os professorescoordenadores de forma a exercer uma reflexão sobre os temas abordados por meio de diversas atividades. As características da cidade de Alfenas como vegetação, clima, entre outras, foi trabalhada de forma integrada com o conteúdo do caderno "Áreas Verdes", possibilitando a constante relação entre o tema trabalhado e a realidade local.

Os professores-coordenadores tiveram total liberdade para trabalhar o conteúdo do caderno com os professores-alunos, que por sua vez, tiveram a mesma liberdade para trabalhar todos os temas em sala de aula. O conteúdo do caderno foi dividido nos seguintes capítulos:

1. Distribuição da vegetação na Terra

1.1 Considerações sobre a vegetação brasileira.

2. A classificação das formações vegetais brasileiras

2.1- Floresta Amazônica

2.2- Mata Atlântica

2.3- Matas de Pinhais (Araucárias)

2.4- Mata dos Cocais

2.5- Mata Galerias ou Ciliares

2.6- Caatinga

2.7- Cerrado

2.8- Campos

2.9- Complexo do Pantanal

2.10- Vegetação Litorânea

3. A Agricultura e o Meio Ambiente 
3.1- O reflorestamento

3.2- O Protocolo de Kyoto

3.3- O ciclo do Carbono

4 - Manutenção e Conservação das Áreas Verdes

4.1- As Unidades de Conservação

5. A Urbanização e as Áreas Verdes

5.1- A cidade e os Problemas Ambientais

5.2- A Necessidade de Implantação de Áreas Verdes

5.3- As funções das Áreas Verdes

6. Caracterização das Áreas Verdes

6.1- Onde estão as árvores da cidade?

6.2- Como as árvores atuam no ambiente?

6.3- Vamos estudar as Áreas Verdes?

7. A Necessidade de Valorização das Áreas Verdes nas Cidades

8. Agenda Verde Escolar e Educação Ambiental

8.1- Entendendo a agenda 21

8.2- Conscientização Ambiental

8.3- Agenda 21 Escolar

8.4- Agenda Verde Escolar

8.5- Sugestão de atividade da agenda verde escolar

9. Roteiro de Análise Ambiental para Trabalho

\section{- Trabalhos de campo}

Segundo Lombardo, Lourenço e Volpe (2007), um primeiro trabalho de campo foi desenvolvido abordando a importância das áreas verdes no clima urbano. Para que este campo fornecesse os resultados almejados, primeiramente verificou-se qual era a taxa de arborização das ruas e praças da área central do município de Alfenas. Em seguida foi desenhado na lousa um croqui da área central da cidade, sobre o qual foram identificados diversos pontos para a coleta de dados de temperatura e umidade relativa do ar pelos professores. Os pontos foram estabelecidos de modo a facilitar a coleta dos dados, tornando-a exeqüível, cobrissem toda área central do município e possibilitassem a comparação dos dados entre áreas arborizadas e 
desprovidas de vegetação. Os professores foram divididos em 10 grupos. Cada grupo ficou responsável pela coleta dos dados de um setor da área central do município. Foram utilizados aparelhos Termômetro-Higrômetro digitais (Hygrotherm Thermo/hygrometer (Foto 6).

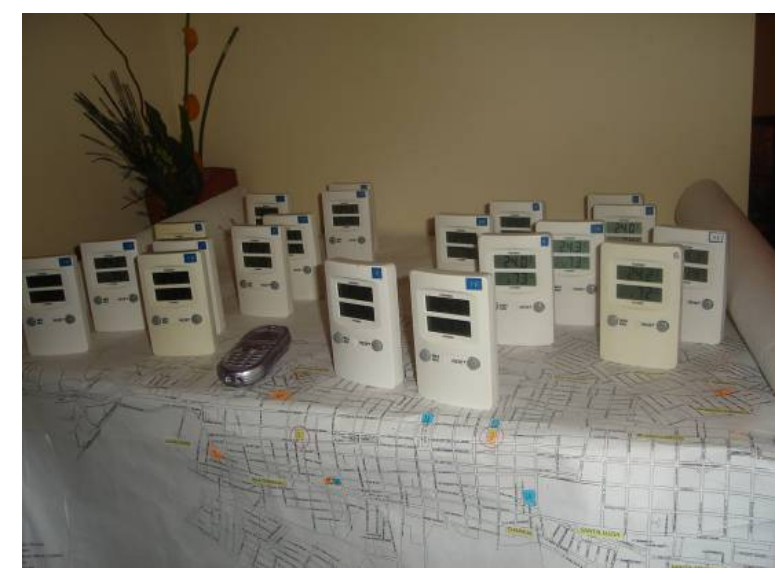

Foto 6: Max./min. Qualitats-Erzeugnis By TFA/ Germany) para a coleta dos dados Foto: Jéferson M. R. M. F. Lourenço

De acordo com Lombardo, Lourenço e Volpe (2007), para aumentar a precisão dos dados, os grupos de professores foram orientados fazer as medições na mesma altura com relação ao solo $(1,5 \mathrm{~m})$ e iniciar as coletas as 15:00 horas. Disponibilizaram-se dois Termômetro-Higrômetros por grupo de professores, que deveriam utilizá-los simultaneamente em cada ponto, para posteriormente tirar a média simples dos dados coletados com os dois aparelhos. No dia seguinte ao campo, os professores apresentaram os dados em sala de aula que foram transcritos na lousa no croqui da área central do município. Feito isto, houve uma discussão dos resultados buscando-se conhecer a avaliação de cada professor-coordenador. Foram traçadas isolinhas sobre o croqui, que serviram para uma melhor visualização dos resultados. Após a avaliação dos dados do trabalho de campo, foi possível perceber uma variação em média de $1^{\circ} \mathrm{C}$ a menos e $4 \%$ de umidade relativa a mais nas áreas centrais de Alfenas providas de arborização com relação às áreas desprovidas. Em uma das praças centrais do município, onde há uma grande concentração de árvores de médio e grande porte e um chafariz, estas variações foram ainda mais acentuadas. O trabalho de campo conseguiu alcançar o seu objetivo principal que era demonstrar a importância da arborização para a melhoria do clima urbano através de uma atividade desenvolvida em equipe pelos próprios professores-coordenadores. Segundo Lombardo, Lourenço e Volpe (2007), parte do conteúdo teórico discutido em sala de aula pode ser aplicado a uma atividade de campo que além de abordá-lo de uma forma alternativa e prazerosa, serviu como estímulo para que alguns 
professores elaborassem suas próprias atividades extra-classe, visando discuti-las com outros professores para posterior aplicação em sala de aula.

Um segundo trabalho de campo foi realizado na área rural de Alfenas-MG, a fim de estudar a vegetação local e suas características, e assim, trabalhar o conteúdo mostrado em sala de aula, principalmente no capítulo que trata dos Biomas.

Segundo a equipe do CECEMCA, de uma forma descontraída, buscou-se estabelecer uma conversa com os professores durante o trabalho de campo visando uma integração entre os professores-coordenadores e a realidade estudada, abordando assuntos como fatores bióticos, abióticos e antropológicos na construção da paisagem e da fisionomia da vegetação.

\title{
- Registros
}

\begin{abstract}
"Os registros são relatórios apresentados que expressam de forma reflexiva a maneira como o conteúdo está sendo trabalhado e quais são os resultados. Os professores foram orientados a elaborar registros diários durante o curso presencial. Para isto. foram trabalhados conceitos e importância dos registros como uma forma de análise reflexiva e colaborativa. Os professorescoordenadores escreviam sobre o conteúdo trabalhado durante o dia, o que se tornou um treino para o trabalho posterior deles com os grupos de estudo" (LOMBARDO, LOURENÇO E VOLPE 2007).
\end{abstract}

Os professores-coordenadores continuaram elaborando registros durante suas reuniões com os professores-alunos, que, por sua vez, também elaboravam registros destas reuniões. $\mathrm{O}$ registro foi a principal forma encontrada pela equipe do CECEMCA de acompanhar e refletir em conjunto com todos os participantes do projeto sobre os temas trabalhados. Tais registros subsidiaram discussões e possibilitaram, tanto à equipe do CECEMCA como aos professorescoordenadores, adaptarem o andamento das atividades às necessidades e dúvidas registradas.

\section{- Projetos e oficinas livres}

Foram elaborados pelos professores-coordenadores, projetos e oficinas para trabalhar com os professores-alunos, baseando-se nas oficinas e nas atividades do caderno desenvolvidas durante o curso presencial. Novas idéias surgiram no decorrer no curso presencial e foram estimuladas, sendo permitido que os professores se expressassem livremente para a criação de suas próprias atividades. 


\section{- Conhecimento de ferramentas de EaD}

A equipe do curso presencial trabalhou com a introdução de uma plataforma de Ensino a Distância chamada Teleduc ${ }^{11}$ (Figura 5) para que, posteriormente, os professorescoordenadores pudessem interagir a distância com a equipe do CECEMCA. Por meio desta plataforma, os professores-coordenadores puderam postar suas dúvidas, sugestões sobre o trabalho com os professores-alunos, tendo o retorno necessário da equipe a distância do CECEMCA.

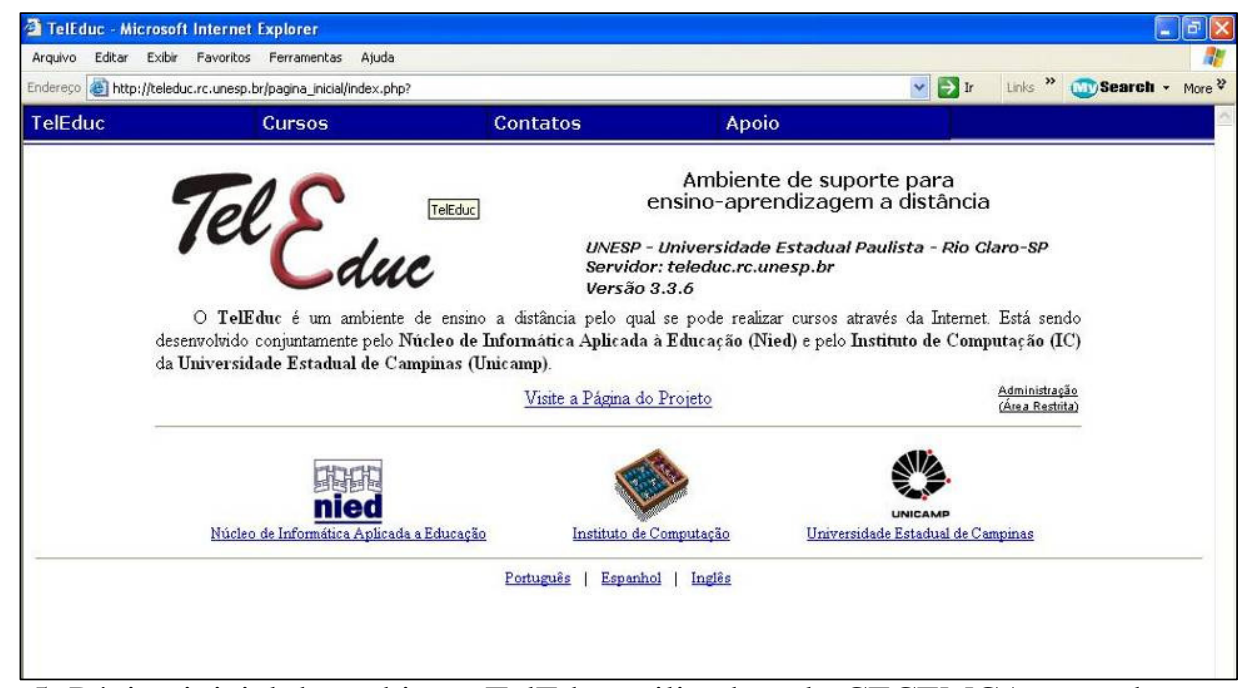

Figura 5: Página inicial do ambiente TelEduc utilizado pelo CECEMCA em todas as suas ações (http://teleduc.rc.unesp.br).

Fonte: Teleduc (2006). Disponível em: teleduc.rc.unesp.br

Também foi utilizada uma ferramenta gratuita de comunicação via Internet chamada skype que possibilita uma comunicação direta e gratuita por meio de mensagens escritas ou telefonemas de computador para computador. Para tanto, durante o curso presencial foram desenvolvidas aulas sobre as ferramentas virtuais utilizadas e conceitos de EaD.

A prefeitura disponibilizou um laboratório de informática para que fosse trabalhado com os professores-coordenadores as ferramentas a serem utilizadas no segundo módulo do curso. No segundo módulo, os professores-coordenadores trabalharam com os professoresalunos em grupos de estudos presenciais, realizaram registros e estabeleceram contato com a equipe do CECEMCA por meio das ferramentas virtuais, skype e plataforma Teleduc.

\footnotetext{
${ }^{11}$ Plataforma virtual desenvolvida pela Universidade Estadual de Campinas, Núcleo de Informática aplicada a Educação, Instituto de Computação. Apoio das agências de fomento a pesquisa FAPESP, CNPq e Organização dos Estados Americanos.
} 
No curso presencial no município de Alfenas - MG, uma análise reflexiva por parte dos professores-coordenadores ocorreu antes mesmo do módulo do Curso a Distância iniciar, permitindo uma integração com o tema e com a equipe do CECEMCA. Ter alcançado uma análise reflexiva foi de extrema importância, pois os professores são os agentes multiplicadores do conteúdo e precisavam de uma visão crítica para coordenar e avaliar os grupos de estudo, que por sua vez, seriam multiplicadores do conteúdo para seus alunos.

Segundo os formadores Larissa Volpe, Jeferson M. R. M. F. Lourenço e a coordenadora Profa. Dra. Magda Adelaide Lombardo, o curso presencial foi fundamental para a continuidade e seriedade do Curso a Distância, pois foi por meio da presença da equipe do CECEMCA que os módulos foram trabalhados e que a dinâmica do curso foi esclarecida. Trabalhar com questões como a densidade do conteúdo dos cadernos e a elaboração dos registros seria muito difícil somente pela plataforma virtual. Muitos assuntos necessitaram de diálogos reflexivos e aprofundados para serem compreendidos e atividades presenciais permitem melhores esclarecimentos, pois nem sempre textos explicitam exatamente a realidade de algumas dúvidas.

\subsection{O Curso a Distância}

Os formadores do CECEMCA acompanharam as atividades dos grupos de estudos (professores-coordenadores e professores-alunos) principalmente por meio da plataforma virtual de EaD - Teleduc.

No módulo à distância foram realizados registros com planejamento das atividades que foram desenvolvidas com os grupos de estudos, elaborados planos de aula (aproveitando os conteúdos estudados) que foram desenvolvidos nas salas de aulas pelos professorescoordenadores, também foram postadas as atividades desenvolvidas em sala de aula pelos professores-coordenadores.

O trabalho de comunicação por meio desta plataforma foi realizado com as ferramentas de interatividade disponíveis. A plataforma Teleduc permite a utilização de diversas ferramentas, mas a equipe do CECEMCA selecionou o uso de algumas.

As ferramentas escolhidas, de acordo com a necessidade dos usuários, foram:

- Estrutura do ambiente: Explanação sobre todas as ferramentas da plataforma;

- Dinâmica do curso: Apresentação do curso para os professores-alunos;

- Agenda: Datas programadas para as atividades e discussões sobre as atividades do curso de maneira geral; 
- Bate-papo: Ambiente que permite a troca de idéias e conversas imediatas (Chat);

- Perfil: Ambiente disponível para que os usuários coloquem seus dados principais como endereço, fotos etc.

- Material de apoio: São postados pelos formadores materiais utilizados durante o curso;

- Fórum de discussão: Ambiente onde é discutido o andamento do curso, as dificuldades encontradas, as reflexões sobre os assuntos desenvolvidos com os grupos de estudos;

- Portfólio: Ambiente que permite anexar arquivos.

A equipe do CECEMCA (coordenadores e formadores) possuía algumas ferramentas a mais do que os professores-coordenadores que permitiam a coordenação e administração das atividades desenvolvidas na plataforma (Figuras 6 e 7).

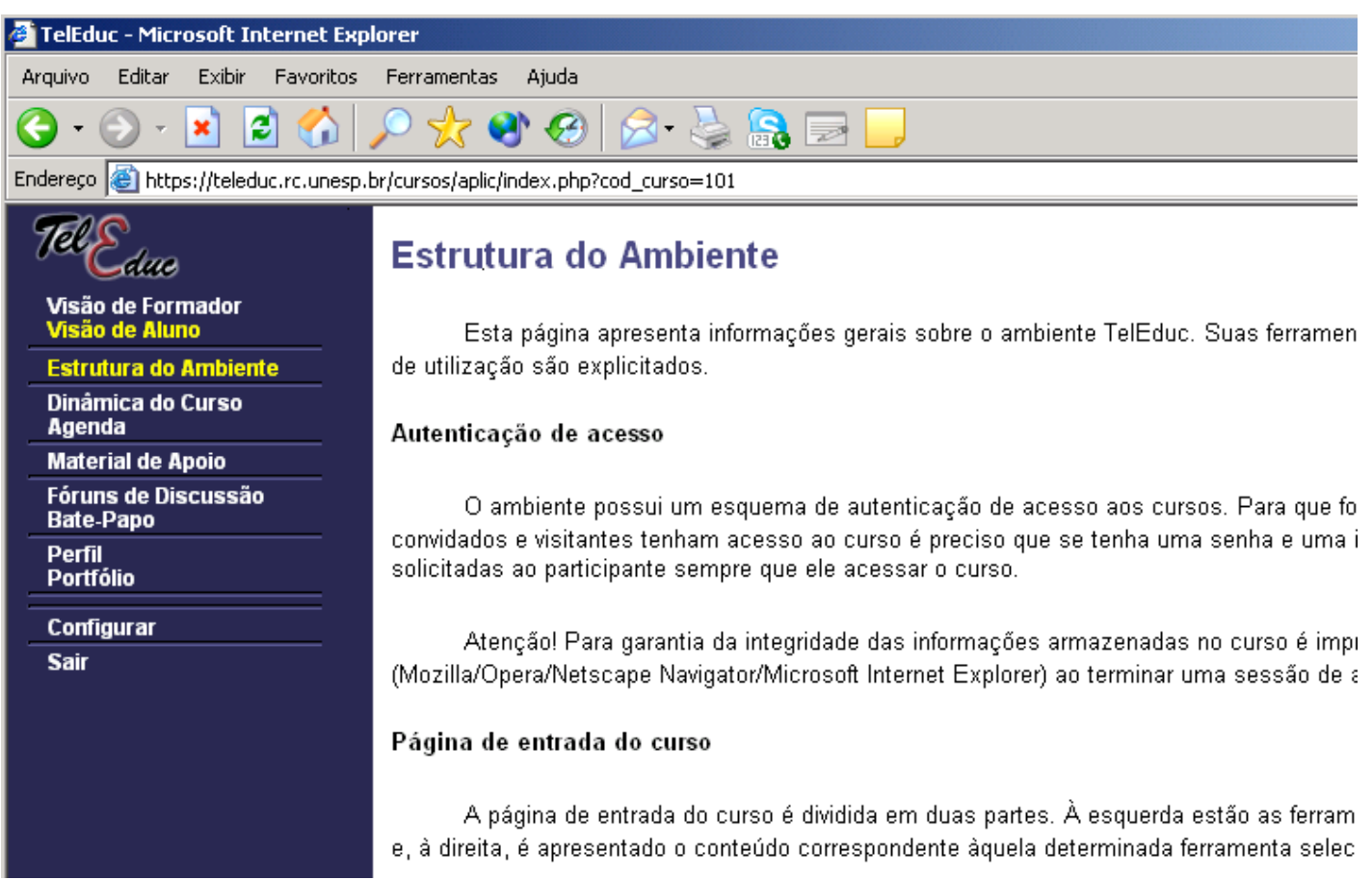

Figura 6: Exemplo da visão do aluno da plataforma Teleduc Fonte: Teleduc (2006). Disponível em: www.teleduc.rc.unesp.br 


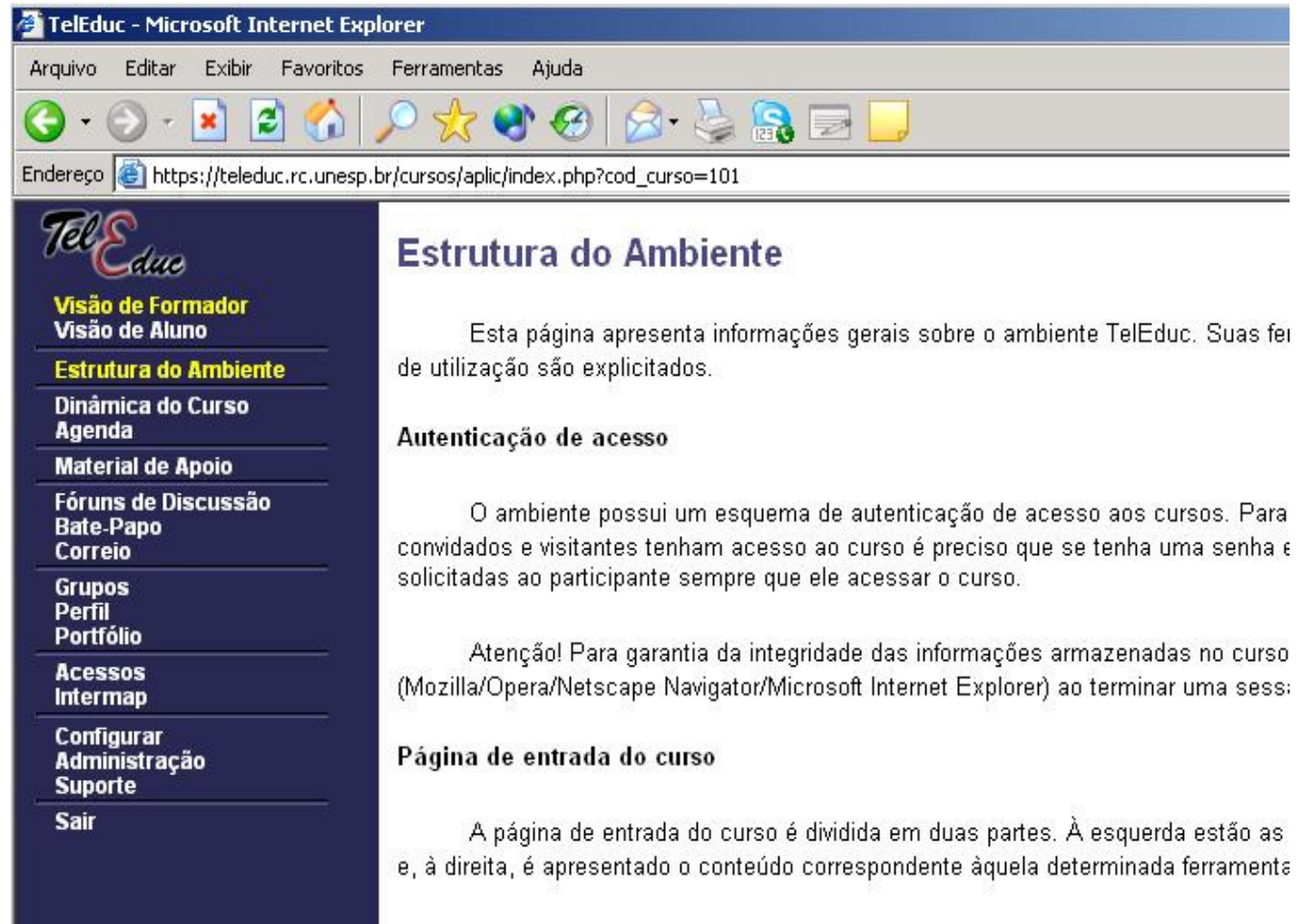

Figura 7: Exemplo da visão de formador (equipe do CECEMCA). Fonte: Teleduc (2006). Disponível em: www.teleduc.rc.unesp.br

Nas figuras 8 e 9 podemos verificar modelos de interação entre professores/coordenadores e a equipe do CECEMCA. Através da plataforma virtual Teleduc, os professores-coordenadores tinham acesso à ferramenta Material de Apoio (figura 8), um ambiente onde eram anexados textos e arquivos de apoio referente ao conteúdo do curso. 


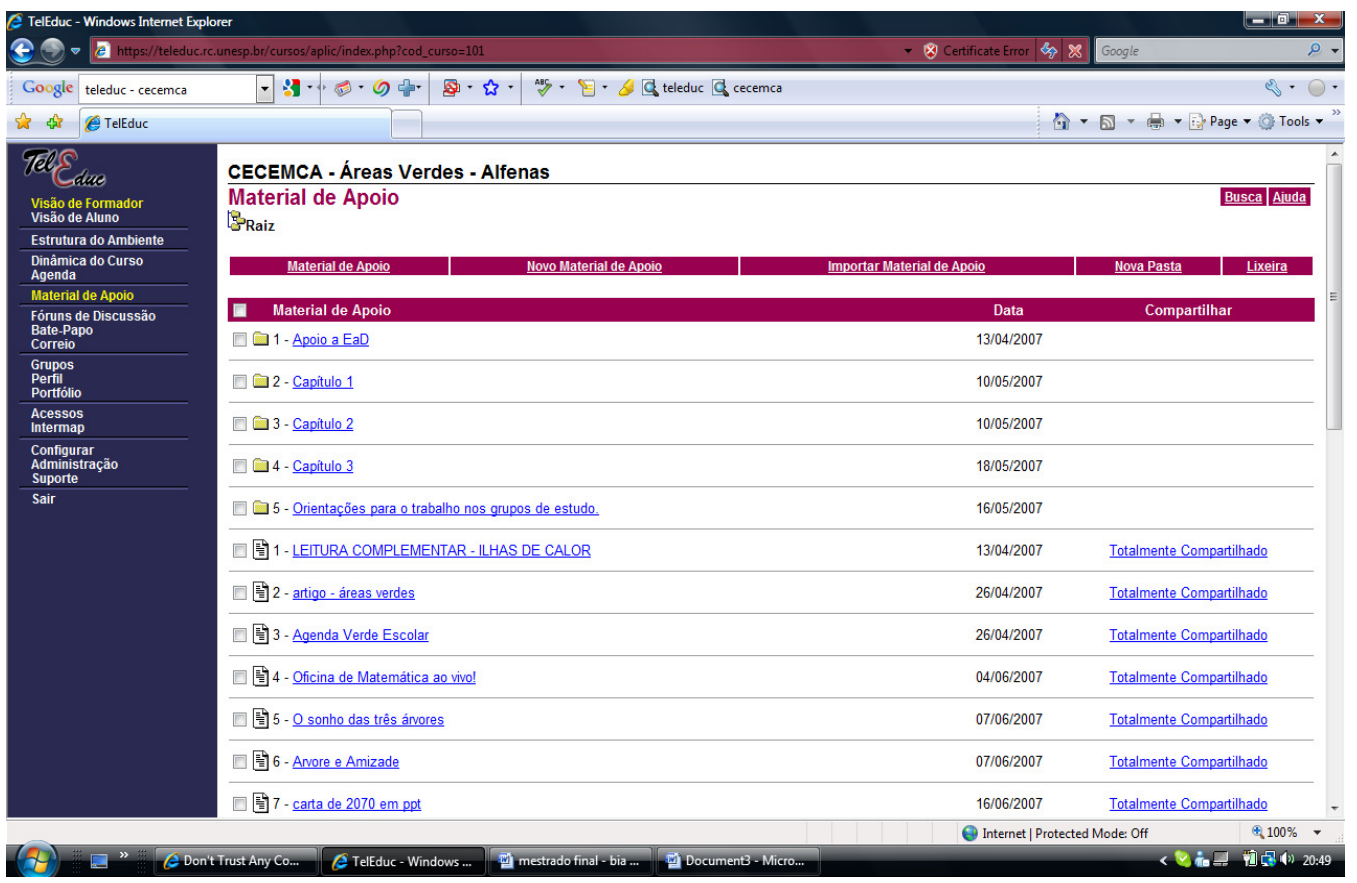

Figura 8: Exemplo de uma pagina utilizada no modulo a distancia pelo grupo na ação de Alfenas. Fonte: Teleduc (2006). Disponível em: www.teleduc.rc.unesp.br

Os participantes também acessavam o Fórum de Discussões (figura 9), no qual tinham acesso a uma pagina com tópicos que estavam em discussão naquele momento. $\mathrm{O}$ acompanhamento da discussão era feito através da visualização de mensagens enviadas e a participação por meio do envio de mensagens. 


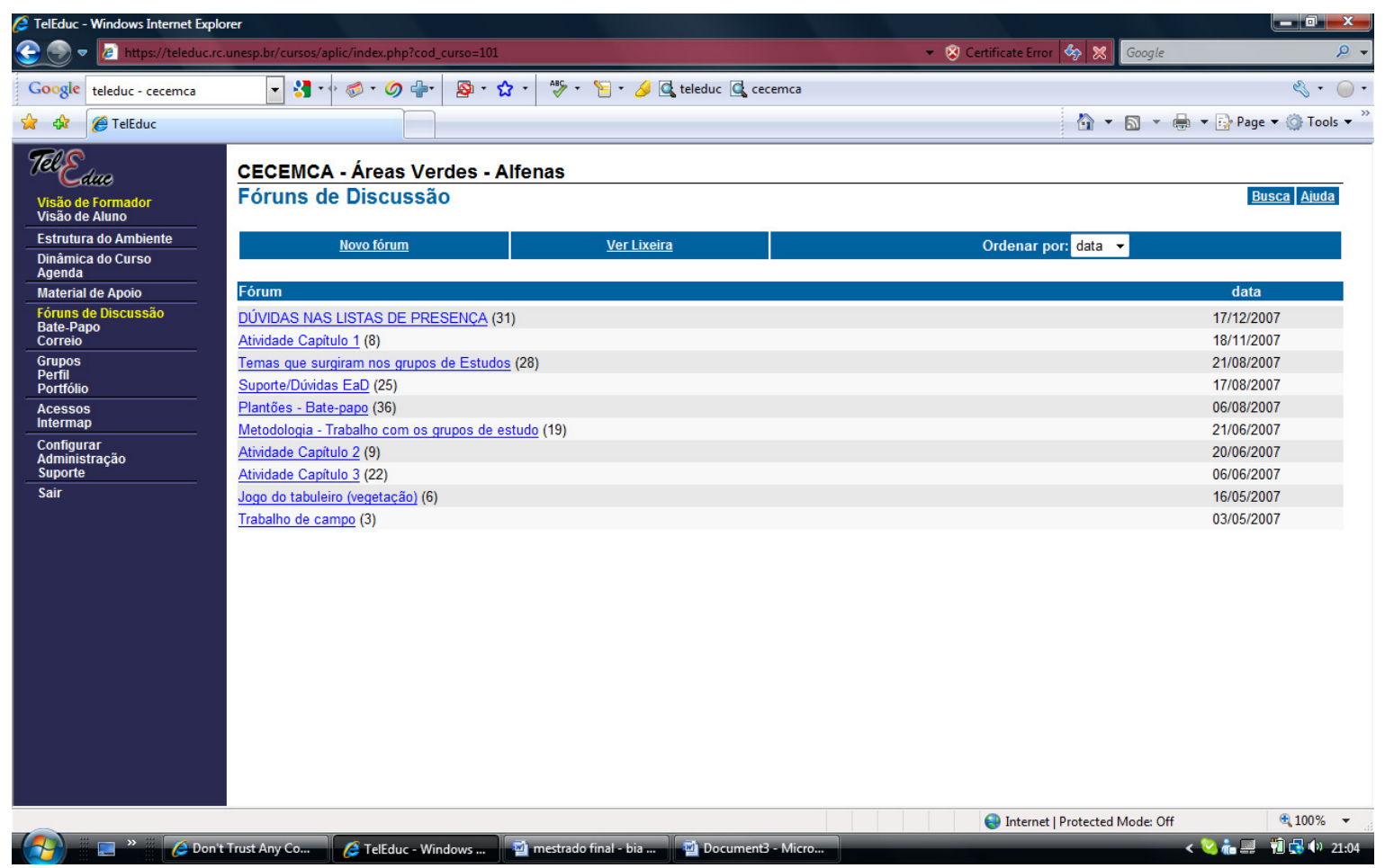

Figura 9: Fórum de discussão, onde os alunos/professores interagiam com a equipe CECEMCA. Fonte: Teleduc (2006). Disponível em: www.teleduc.rc.unesp.br

No caso descrito na figura 10, por exemplo, foram postadas dúvidas sobre as atividades do capítulo 1 do caderno "Áreas Verdes". A dúvida quando a postagem da atividade foi esclarecida pela formadora e postada de volta no Fórum de Discussões. 


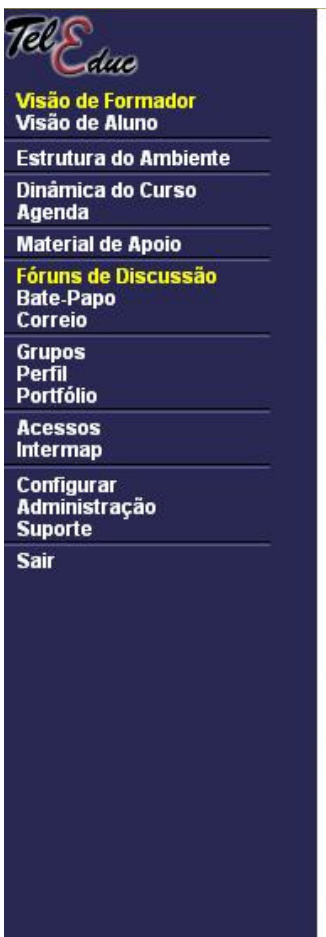

CECEMCA - Áreas Verdes - Alfenas

Fóruns de Discussão - Ver Mensagem

Mensagem do Fórum Atividade Capitulo 1

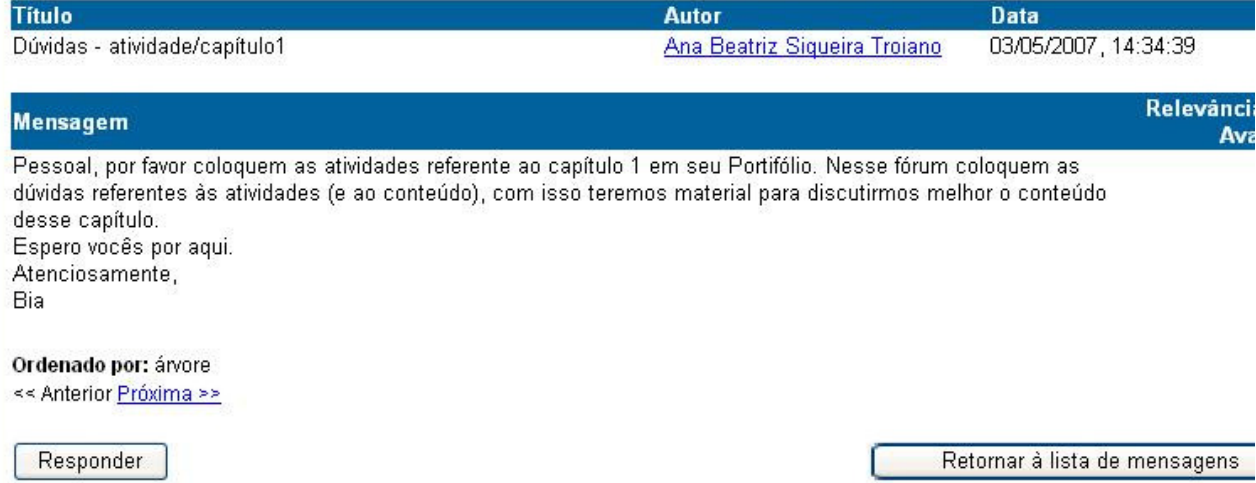

\section{Analisar Relevância}

Muito Relevante

Relevante

Relevância Média

Pouco Relevante

Não Relevante

Figura 10 - Resposta para dúvida do professor-coordenador postada no Fórum de Discussões pela formadora Ana Beatriz Siqueira Troiano (2007)

Fonte: Teleduc (2006). Disponível em: www.teleduc.rc.unesp.br

A ferramenta Correio também foi muito utilizada, funcionando como uma caixa de email interna, onde somente os participantes poderiam interagir. O Correio possibilita o envio de mensagens individuais ou para todos, enquanto o Fórum de Discussões fica aberto pra todos os participantes. A figura 11 ilustra mensagens postadas pelos formadores. 

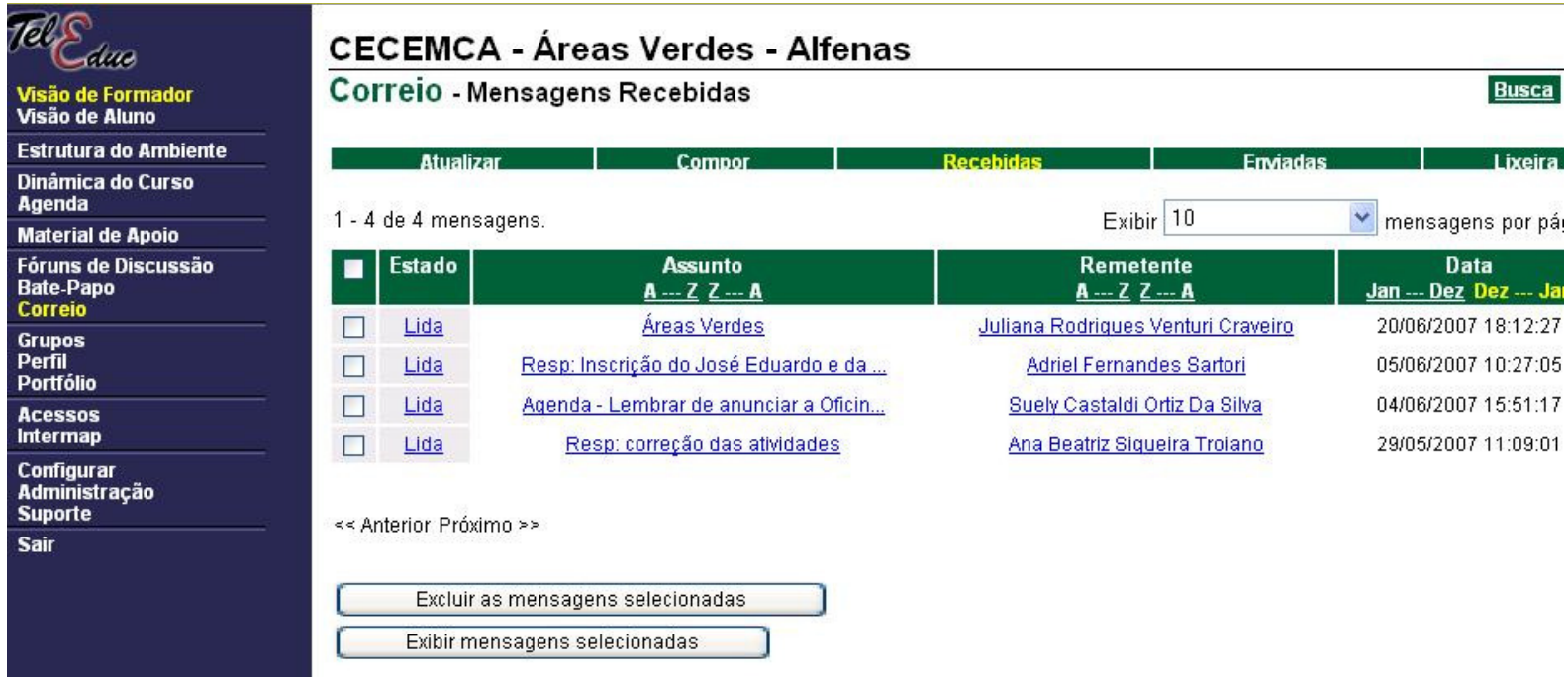

Figura 11: Mensagens postadas pelos formadores utilizando a ferramenta correio na plataforma Teleduc.

Fonte: CECEMCA (2007)

\section{- Critérios para Certificação}

Para a obtenção do certificado, foram avaliados o cumprimento de todas as atividades propostas nos módulos, mediante um parecer favorável dos respectivos responsáveis, postagem dos registros semanais referentes aos planos de trabalhos realizados com os grupos de estudos (para o professores-coordenadores) e sobre as discussões ocorridas nos grupos de estudos, (para professores-coordenadores e professores-alunos).

Foi necessária a realização de um plano de aula, cuja temática estava vinculada ao conteúdo estudado no curso e apresentação dos resultados da aplicação dos planos de aulas com os alunos nas escolas. 


\section{DISCUSSÃO DOS RESULTADOS}

Um fato importante a ser ressaltado no curso realizado no município de Alfenas - MG foi a compreensão cada vez maior por parte dos professores-coordenadores (tutores) em permitir que os grupos de estudos se tornassem pontos de referências para discussões e socialização de novos conhecimentos. Também foi muito importante a amplitude das discussões e aprofundamento das variáveis existentes na questão da Educação Ambiental dentro do ambiente escolar.

Uma compreensão ampla por parte da Secretaria de Educação do Município sobre os benefícios dessa formação junto aos professores da Rede Municipal de Ensino de Alfenas permitiu um apoio incondicional da mesma para a aquisição de materiais e recursos para o enriquecimento do curso, bem como uma orientação clara aos diretores e supervisores para auxiliarem os grupos de estudos em cada escola.

A partir do momento em que a coordenadora do curso Profa. Dra. Magda Adelaide Lombardo conversou com os professores-coordenadores sobre o filme "O que foi", percebeuse um envolvimento com o tema, tendo eles, inclusive, solicitado uma cópia do DVD para trabalhar com seus alunos. No curso presencial, os formadores explicaram de que forma eles deveriam trabalhar o conteúdo com um grupo de estudo formado por outros professores, e não diretamente com seus alunos. Segundo a formadora Larissa Volpe, "a idéia de trabalhar com outros professores foi melhor compreendida no decorrer do curso e não logo no primeiro dia".

No início do curso, segundo os formadores, as dúvidas que surgiram foram sobre o cronograma, pois a carga horária de trabalho dos professores é sempre muito densa e existe a insegurança de não conseguirem acompanhar o andamento do curso; sobre o EaD; dúvidas em relação ao acompanhamento do Curso a Distância, equipamentos disponíveis, internet etc.

Foi notado o pouco acesso aos computadores por parte dos professores, principalmente, pelo fato de alguns professores não possuírem e-mail, outros não tinham conhecimento dos procedimentos básicos de informática ou Internet.

Porém, com o andamento diário do curso presencial, os professores-coordenadores puderam perceber que existia a possibilidade da realização e conclusão do curso, mesmo com o tempo limitado, e isso seria possível por se tratar de um curso semi-presencial, onde uma grande parte do trabalho a ser realizado por eles seria via computador, no melhor horário, sendo assim, não ficariam presos a um horário de trabalho diário. O uso da Internet permitiu que os professores adaptassem seus próprios horários para a realização do curso. 
Em relação ao conteúdo do caderno surgiram algumas indagações, segundo o relato do formador Jeferson Lourenço. “Ao iniciar uma aula sobre Biomas / Domínios / Ecossistema, alguns professores, apesar de interagirem, reclamaram que o conteúdo seria muito denso, uma vez que muitos professores-alunos ministram aulas para crianças pequenas, e que elas não teriam, ainda, capacidade para acompanhar um conteúdo tão específico." Nesse momento, os formadores explicaram que o conteúdo passado para os professores-alunos poderiam ser densos, de forma que eles discutissem o tema e as idéias de como passar o tema para seus alunos deveria partir deles por meio de oficinas, projetos, aulas etc. Um ponto importante, segundo os formadores da ação presencial do CECEMCA, foi que, após essa discussão sobre a forma de trabalhar com os professores-alunos, o objetivo do CECEMCA ficou mais claro para os professores. Foi esclarecido que o conteúdo que seria trabalhado com eles deveria ser adaptado de acordo com o ano, a faixa etária e o cotidiano dos alunos para quem esses professores ministravam aulas.

No decorrer dos dois módulos do curso, presencial e a distância, o caderno "Áreas Verdes" forneceram base para discussões e dinâmicas que fizeram com que os professorescoordenadores e os professores-alunos trabalhassem com a realidade local, envolvendo algumas características da cidade de Alfenas como clima, vegetação, poluição e ações humanas. O caderno também mostrou que é possível a elaboração de projetos livres parte de todos os participantes do curso, envolvendo desde a escola, a comunidade, até outras entidades públicas e particulares, mostrando a importância da participação de diversos segmentos da sociedade.

Em relação aos registros, foi explicado pelos formadores que os professorescoordenadores deveriam expressar o que pensavam a respeito do conteúdo das aulas, do caderno, para assim, expor idéias, novos projetos, entre outras possibilidades. Foi explicado também que eles deveriam passar esta idéia de registro para o grupo de estudo formado pelos professores-alunos.

Segundo a formadora Larissa Volpe "o que foi observado no primeiro registro no curso presencial dos professores-coordenadores foi apenas uma descrição da aula em relato de dúvidas, críticas e sugestões sobre o curso. Pelo fato de não se ter alcançado o objetivo do primeiro registro, esse tema foi tratado uma segunda vez, de modo que, para os professorescoordenadores os registros deveriam ser uma forma de expressão, reflexão do tema trabalhado no dia, e que deveriam servir como base para a elaboração de novos projetos. Da mesma forma, os professores dos grupos de estudos foram orientados a registrar as atividades realizadas nos encontros com os coordenadores de grupos, a partir de uma perspectiva 
colaborativa e reflexiva." Tais registros subsidiaram parte das discussões dos grupos de estudos e possibilitaram aos professores-coordenadores adaptarem o andamento das atividades de encontro, de acordo com as necessidades e dúvidas registradas.

É importante lembrar que as atividades de encontro entre professores-coordenadores e professores-alunos foram acompanhadas a distância pelos formadores do CECEMCA através do uso da plataforma virtual de $\mathrm{EaD}$ - Teleduc, o que permitiu o uso de um fórum de discussão permanente com os formadores para verificação do andamento das atividades dos grupos de estudos e, que em caso de dúvida ou necessidade de material complementar, os formadores os auxiliaram através do fórum de discussões e postagem de materiais complementares na plataforma.

Os professores-coordenadores foram orientados a elaborar uma pauta para cada encontro realizado, que foi submetida aos formadores do CECEMCA antes de cada encontro, e assim, foi possível orientá-los ou auxiliá-los na explanação de alguns dos conteúdos trabalhados. Porém, vários professores-coordenadores residem e atuam na zona rural do município e em alguns lugares não há acesso a computadores, tampouco Internet. Isso ocasionou um atraso e uma sobreposição na maioria das postagens da pauta e do registro do encontro, pois tudo era postado de uma só vez, e semanalmente, dificultando a orientação dos formadores da equipe do CECEMCA para a reelaboração da pauta de trabalho dos professores-coordenadores. A falta de acesso a computadores e internet dificultou, em parte, o andamento do Curso a Distância, pois os professores-coordenadores tinham as atividades acumuladas algumas vezes, mas no geral, embora existisse a dificuldade mencionada, os professores-coordenadores apresentaram boa disposição para postar não apenas os registros pessoais sobre os encontros, mas também as atividades realizadas e registros dos professores participantes.

Outro ponto interessante da formação foi o grande interesse despertado pelo tema meio ambiente, o que permitiu que professores-alunos e professores-coordenadores ampliassem o foco de discussão para inúmeras questões que envolvem o desenvolvimento sócio-econômico do município e o impacto do mesmo sobre o meio ambiente, em especial a proximidade do reservatório da hidrelétrica de Furnas. Neste ponto, o trabalho a distância se manteve através da disposição para acesso diário dos formadores à plataforma virtual, a fim de se manterem atentos às demandas dos professores-coordenadores, e assim permitir a manutenção de um diálogo que enriquecesse ambos os lados dessa formação. 
A partir das discussões provenientes das oficinas e textos trabalhados, os professorescoordenadores foram orientados a elaborar e discutir um plano de aula com os professoresalunos, para então, aplicá-los em sala de aula.

Segundo os formadores, os resultados do curso presencial foram satisfatórios, a carga horária foi suficiente para trabalhar o tema do caderno. Porém, uma carga horária presencial maior permitiria trabalhar mais o conteúdo de diferentes formas, já que as maneiras de se trabalhar o tema “Áreas Verdes” são inesgotáveis.

Por meio da leitura dos registros foi possível notar que há interesse na aplicação do conteúdo do caderno "Áreas Verdes” de diversas formas para os grupos de estudo. Segundo a equipe do CECEMCA do curso presencial, houve muitas discussões sobre o conteúdo, o que tornou possível uma análise crítica e reflexiva do caderno "Áreas Verdes" por parte dos professores-coordenadores, não havendo apego somente ao conteúdo em si, mas também às reflexões que o tema trouxe.

A boa receptividade dos professores-coordenadores, bem como o interesse da Secretaria de Educação do Município de Alfenas pela formação oferecida, permitiu a organização rápida dos grupos de estudos e todos os professores da Rede Pública de Ensino participaram do curso.

Abaixo, estão alguns comentários relacionados aos registros dos professorescoordenadores sobre o desenvolvimento das atividades dos grupos de estudos, bem como registro dos professores-alunos e algumas das atividades realizadas em sala de aula pelos mesmos.

\section{Síntese do relatório do professor-coordenador}

No primeiro encontro, percebi que todos estavam um pouco ansiosos e apreensivos em relação ao curso. Como ainda não dispunha do caderno Áreas Verdes, optei por uma competição, a qual foi muito bem aceita. Primeiro fiz a apresentação do caderno, o qual eles receberão no próximo encontro e uma explanação da dinâmica do curso. Levantei 22 curiosidades em relação ao meio ambiente e fiz algumas alterações nelas de maneira que algumas fossem falsas. Pedi que os participantes do curso se colocassem no final da sala, um do lado do outro e dei-lhes um cartão que de um lado estava escrito certo e do outro errado. Eu lia as questões de maneira afirmativa e eles me respondiam se estava certo ou errado e quem acertava dava um passo a frente em direção a um presente que estava no início da sala. A cada questão apresentada, discutíamos sobre o assunto exposto e foi muito produtivo. Quando chegamos a questão 22 e tivemos um vencedor, ele pensou que levaria o premio, mas então entrei com a dinâmica do presente, adaptada ao assunto meio ambiente, onde o presente acaba passando por todos os participantes e no final é dividido por todos.Após esse momento, pedi-lhes que fizessem o relatório.

Professora-coordenadora 


\section{Síntese dos relatórios dos professores-alunos}

Achamos esse primeiro encontro muito proveitoso e descontraído, percebemos que mesmo através de uma brincadeira é possível repassar informações e discuti-las com entusiasmo.

Foi muito interessante a maneira com que nos foi passado a introdução do curso, isso nos deixou muito a vontade com a dinâmica utilizada e aprendemos curiosidades que desconhecíamos.

Através deste projeto cria-se a possibilidade, reflexiva de um trabalho com a educação infantil de sensibilização de que somos parte da natureza e vice-versa.

Este curso será um meio de possibilidades de conscientizarmos de que não somos detentores e controladores do nosso planeta.

Esperamos que no decorrer deste curso, possamos sanar nossas duvidas e dificuldades e que o assunto lixo e reciclagem estejam presentes entre os temas abordados e que os próximos encontros sejam iguais a esse primeiro.

Professora-coordenadora

Dentro deste contexto, é importante ressaltar que a dinâmica adotada pelos professores-coordenadores propiciou momentos de discussão importantes dentro dos grupos de estudos, levando-os a modificar a apresentação do conteúdo ao observarem as dificuldades apresentadas pelos professores-alunos em seus grupos de estudos.

Um dos pontos mais interessantes dessa formação foi o enfoque das discussões para a compreensão da questão ambiental relacionando não apenas o tema "áreas verdes" e a "agenda verde", mas também o impacto das atividades humanas geradas pelo consumo irresponsável e a conscientização de que a preservação do meio ambiente deve envolver as escolas e a sociedade como um todo. Mostraram assim que possuem grande discernimento em compreender que ações de conscientização efetivas só serão possíveis se houver interesse e mobilização das comunidades envolvidas, com integração das escolas neste contexto.

Abaixo estão alguns comentários relacionados aos registros dos professorescoordenadores sobre o desenvolvimento das atividades dos grupos de estudos, bem como registro dos professores-alunos.

\section{SÍNTESE SOBRE O $3^{\circ}$ ENCONTRO}

Este encontro foi bem interessante. Primeiro começou com bastante descontração, pois a dinâmica do Pêndulo nos fez rir, relaxar e descontrair bastante o que é importante depois de um dia todo de trabalho. 
Mas depois o encontro tornou-se muito sério, ao ver os desastrosos resultados que o homem vem colhendo após séculos de vida em cidades mal planejadas, realmente, as expectativas não são as melhores para os próximos séculos.

Podemos resumir tudo assim:

- Devanir - Fomos "estragados", precisamos de uma geração educada para agir com consciência;

Leila _ O trabalho de melhorar o planeta deve ser solidário, a maioria não está preparada para isso;

_ Laura_As funções do verde urbano precisam ser transmitidas a população em geral;

- Patrícia _ Gestos simples como plantar uma árvore frutífera no quintal de casa, está ao alcance de quase todos;

_ Mara _ Se trouxermos a família para dentro da escola e lançarmos campanha em parceria, tudo pode ser mais fácil;

_ Gilcéia _ Escolhemos a qualidade de vida que queremos ter quando escolhemos o que fazer com o meio ambiente;

_ Marisi _ Mesmo os que não tem quintal de terra, podem plantar em vasos e depois doa-los a quem possui espaço maior;

_ Neide _ Nosso planeta não se tornou o que é da noite para o dia, porém não será do dia pra noite que mudaremos tanta destruição. Precisamos fazer algo com as crianças já;

- Adriana _ As atividades de intervenção precisam acontecer conforme a realidade de nossos alunos ( eles são de zona rural);

Mercês - É de pequenino que se torce o pepino. Para a educação ambiental é preciso firmeza;

Solange - Não se pode esquecer que nós também estamos aprendendo a cada encontro;

_ Juscélia _ Preciso confessar que estou me tornando mais consciente por meio deste curso;

Nilda - Realmente, tem muito pra fazer, mas precisamos mudar o lugar em que estamos e incomodar os que nada fazem.

Somente como equipe, na escola ou fora dela, o ser humano vai fazer a diferença dentro de um planeta tão grande!

Professora-coordenadora

Fonte: CECEMCA (2008) 
Dentro do princípio que norteou essa formação, os professores-coordenadores apresentaram ao CECEMCA, não apenas os registros dos encontros, mas disponibilizaram as atividades elaboradas para explanação de alguns conceitos discutidos no âmbito dos encontros dos grupos de estudos e tentaram associar os temas às questões naquele período.
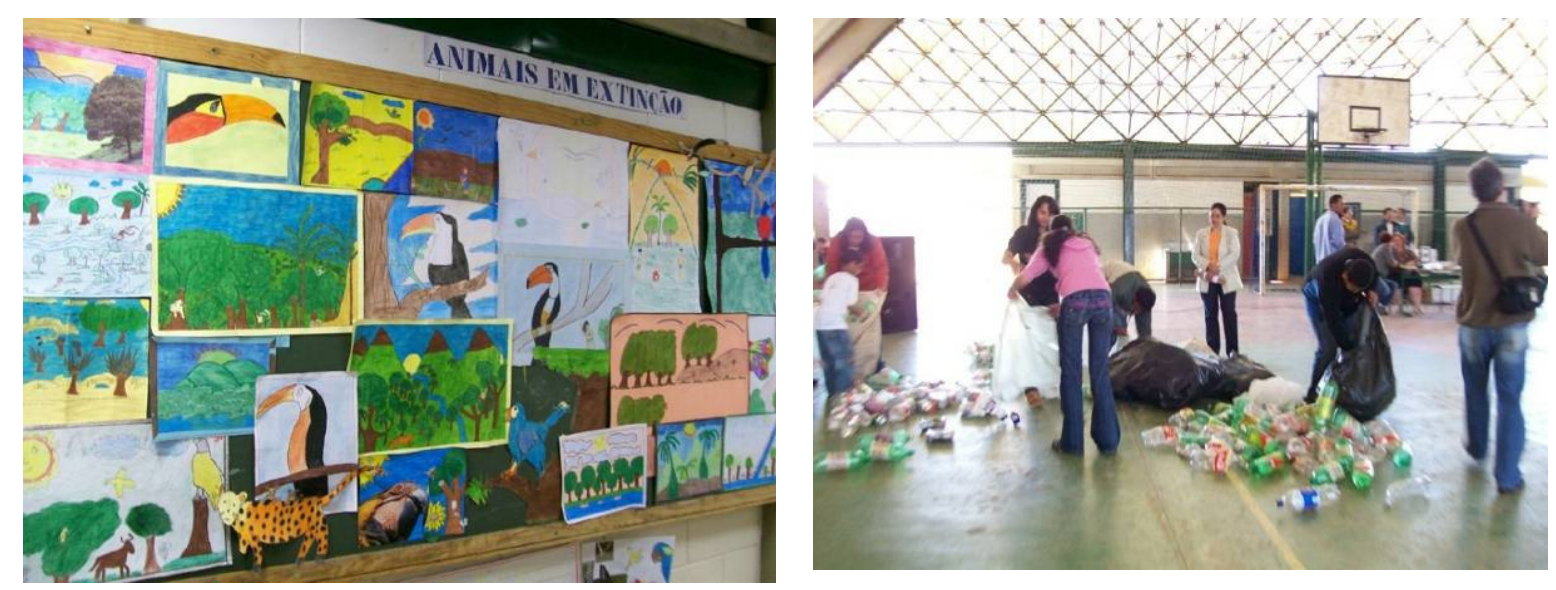

Foto 7 e 8 : Atividades Realizadas pelos professores do grupo de estudos coordenado pela tutora Wilma Azevedo. "Preparação para a comemoração do "Dia do Meio Ambiente". Fotos: Wilma Azevedo, 2007.

Um dos pontos altos dos encontros foi a compreensão do alcance de algumas das atividades propostas: a agenda verde escolar, que permitiu discussões e a compreensão de que é possível mobilizar toda a comunidade e entidades interessadas em prol de um objetivo de interesse amplo e permitirá também trabalhar a interdisciplinaridade para alcançar os objetivos. 
A síntese apresentada abaixo é originária dos registros dos professores-coordenadores, bem como dos professores que participaram dos grupos de estudos.

\title{
RELATÓRIO-SÍNTESE DO $4^{\circ}$ ENCONTRO DO GRUPO DA ESCOLA MUNICIPAL ARLINDO SILVEIRA
}

\begin{abstract}
“ÁREAS VERDES"
Após, a reflexão acerca da mensagem "Só depende de nós", fizemos a leitura cruzada da síntese dos capítulos estudados, onde debatemos e vimos que o homem é o grande destruidor da natureza, porém é também o responsável pela preservação da mesma.

Através do relato do morador mais velho do bairro, analisamos juntos com os alunos o antes e o agora do bairro, levando-os a questionar as formas de preservação do meio e como construir sem destruir.

Com experiência proposta nas páginas 90 e 91, levamos os alunos para fora da sala de aula para envolvê-la. Assim, puderam perceber a importância de se ter solos permeáveis e protegidos com diversos tipos de vegetação permitindo a infiltração da água evitando a erosão e, desta forma, o abastecimento dos lençóis freáticos.

Com esta experiência fizeram a comparação dos solos das cidades onde as águas das chuvas encontram a barreira da impermeabilidade causando as enchentes, enquanto, que no campo, a água encontra caminhos para a infiltração.

Dentro das atividades propostas foi solicitado aos alunos para listarem as diferentes espécies de arvores que são comuns à região onde moram (de casa até a escola). Além da listagem foi coletado folhas e sementes para a confecção de um mural. As espécies coletadas foram: sibipiruna, cedro, ipê amarelo e roxo, jatobá, cafezinho, amendoinzeiro, incluindo arvores frutíferas como: araçá, amoreira, etc. $\mathrm{O}$ araçá é uma espécie de arvore que dá um fruto parecido com a goiaba. Ela dá no meio dos pastos. Hoje em dia está em extinção, mas na nossa região ainda é possível encontrá-la.

$\mathrm{O}$ mural foi exposto à comunidade escolar (pais e visitantes).

Os textos estudados e atividades realizadas não apresentaram dúvidas ou dificuldades, pois são de fácil entendimento.

Ao encerrarmos o trabalho, chegamos à conclusão de que basta haver planejamento para acontecer à preservação.

Professora-aluna
\end{abstract}

Fonte: CECEMCA (2008) 
Não houve registro por parte dos professores-coordenadores quanto a alguma dificuldade que pudesse ocasionar problemas na condução de seus respectivos grupos, nem as atividades desenvolvidas (Fotos 9 e 10).

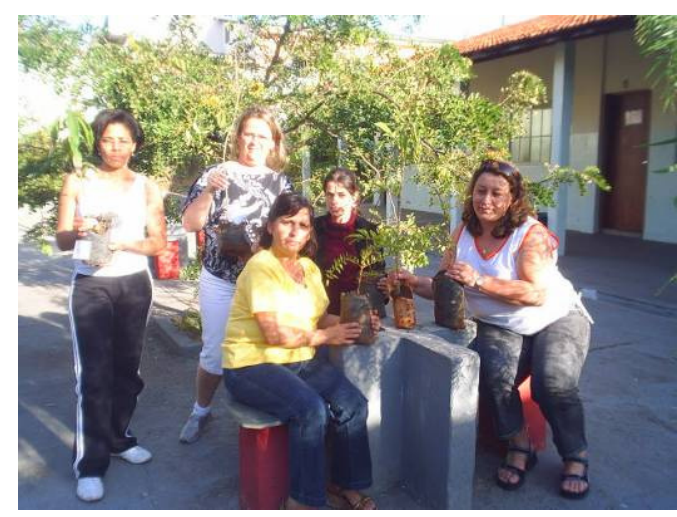

Foto 9: Grupo de estudos e mudas frutíferas

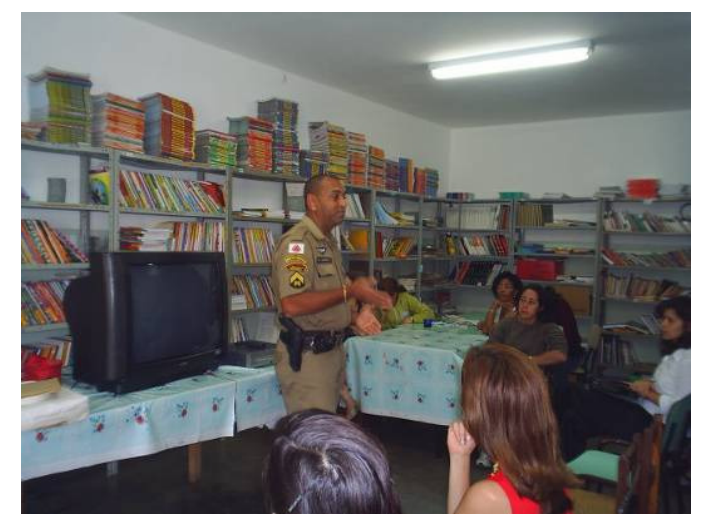

Foto 10: Palestra sobre legislação ambiental Fotos: Sandra Moreira (2007)

Dentro desse processo, as discussões que surgiram no decorrer dos encontros realizados permitiram a observação de que os problemas ambientais observados e discutidos no âmbito do grupo de estudos se estendeu para uma intervenção prática nas comunidades próximas às escolas.

As características apresentadas por essa formação certamente permitiram um resultado positivo junto aos alunos em suas salas de aulas, pois a administração e equipe de professores das escolas compreenderam a importância do processo de formação continuada.

\subsection{Análise da opinião dos professores-coordenadores}

O curso dos professores-coordenadores é considerado um curso semi-presencial, já que contou com dois módulos, presencial e a distância. Sendo assim, o grupo participante teve a chance de avaliar o curso. Foi aplicado um questionário para os professores-coordenadores para que a equipe do CECEMCA pudesse analisar o curso, seus potenciais e suas limitações. Do total de professores que participaram do curso, 16 professores-coordenadores responderam ao questionário aplicado pelo CECEMCA (ver anexo A).

As repostas dos professores-coordenadores com relação ao curso foi muito positiva, todos consideraram o curso realizado muito proveitoso para a valorização de muitos conceitos que envolviam a educação ambiental. Em análise, é visto que assuntos relacionados às discussões da atualidade como "Aquecimento Global" e o papel das áreas verdes para o minimizar os impactos deste processo, foi muito discutido e pôde acrescentar novos 
conhecimentos, e principalmente, incluir tais assuntos no cotidiano escolar. Outro ponto muito positivo apontado pelos professores-coordenadores foram os grupos de estudos em si, que propiciaram uma grande interação entre todos os professores envolvidos e a escola ao qual estavam associados. Os grupos de estudos permitiram a discussão e apresentação de novos conhecimentos, bem como a socialização das experiências de cada um com o tema e a sua aplicabilidade em suas respectivas disciplinas.

Através de pesquisa, leitura e atividades propostas pelo caderno “Áreas Verdes”, todos os participantes demonstraram terem atualizado seus conhecimentos e, além disso, a troca de experiências e informações entre todos os membros do grupo (professores-coordenadores, professores-alunos e a equipe CECEMCA) enriqueceu a formação do profissional.

Através da leitura do caderno “Áreas Verdes" que propõe textos e atividades, os professores-coordenadores sentiram que a atualização dos seus conhecimentos era feita de maneira prazerosa, pois o conteúdo do caderno era de fácil compreensão, levando à reflexão sobre as questões ambientais. Além disso, nas atividades propostas pelo caderno e nas atividades postadas na plataforma virtual Teleduc, os professores-coordenadores atualizavam seus conhecimentos através de pesquisas realizadas para o cumprimento das atividades propostas ou pelas discussões encadeadas no Fórum de discussão da plataforma Teleduc.

Todos os membros dos grupos de estudo foram unânimes em considerar a boa receptividade dos professores-coordenadores para as discussões nos grupos de estudos e estas respostas foram um excelente parâmetro para os professores-coordenadores avaliarem sua atuação.

Apesar da opinião que o curso deveria ter um tempo de duração maior, a maioria do professores relatou um bom aproveitamento daquilo que foi trabalhado. O conteúdo apresentado pelo caderno "Áreas Verdes" despertou interesse nos participantes, e os temas abordados suscitaram discussões reflexivas. Os professores afirmaram que a partir das discussões e trabalhos realizados, a consciência sobre o que significa a educação ambiental foi ampliada, enfatizando-se a interdisciplinaridade da mesma.

O trabalho com os grupos de estudos foi avaliado como bom pelos professores-alunos de acordo com os professores-coordenadores que recebiam as avaliações dos membros dos grupos de estudo ao final de cada encontro através dos registros.

De acordo com os formadores do CECEMCA, o trabalho desenvolvido através da plataforma virtual Teleduc requer, como condição de aproveitamento máximo em todas suas fases, de significativo domínio das ferramentas básicas da mídia utilizada e de condições de acesso às redes provedoras desta mídia. Tais condições, à medida que vão sendo alcançadas, 
asseguram melhor desempenho e segurança nos módulos de trabalhos a distância e conseqüente otimização dos conteúdos e dinâmicas próprios desta plataforma.

Um ponto importante ressaltado pelos professores-coordenadores foi a importância de se trabalhar a realidade do local. Por meio do conhecimento das características da cidade como clima, vegetação, população, entre outros, as pessoas começam a se interessar, se preocupar e interagir com as questões ambientais locais, inserindo-se posteriormente em um contexto global. Os professores tornam-se mais críticos com as questões ambientais, e por meio de suas aulas e projetos, fazem com que toda a equipe escolar se envolva e seja motivada para a execução de futuros projetos na área ambiental.

Segundo os professores que responderam os questionários, o fato de terem trabalhado com grupos de estudos formados por professores de diferentes áreas enriqueceu a formação através da interdisciplinaridade, pois havia diferentes perspectivas sobre o meio ambiente, fazendo assim, com que as discussões fossem ricas em diferentes aspectos sobre o mesmo tema, no caso "Áreas Verdes e Meio Ambiente".

Os professores afirmaram que o caderno “Áreas Verdes” apresentou-se como um excelente material, com linguagem simples e muitas atividades interessantes, já que não ficava estagnado em textos teóricos, pois ao abordar a realidade local, os professores deveriam interagir o material do caderno com a sua realidade local. Também foi levantando que o caderno era repleto de ações e apresentava um ótimo processo educativo.

Foi ressaltado também que, através de gestos corriqueiros, os professores poderiam atingir seus objetivos em relação à preservação do meio ambiente e levar os alunos e a população a perspectivas de mudanças de comportamento.

Nas respostas dos questionários foi também levantada a questão da valorização do professor, pois ao trabalhar conceitos de meio ambiente ligado ao cotidiano do local onde vivem, os professores despertam nos alunos o interesse pelo meio ambiente de sua rua, seu bairro e sua cidade. Os alunos passam a ver o professor como alguém que busca interagir, mostrar os problemas locais, despertar o interesse pela busca de soluções. Os alunos passaram a levar o conhecimento adquirido para fora da escola e trabalhar dentro de suas casas, com seus familiares, e podem ver o resultado das atividades propostas pelos professores.

Ainda em relação ao curso ter sido aplicado de maneira semi-presencial, muitos avaliaram como fator positivo a flexibilidade de horário que eles tinham para a realização das atividades, pois não ficaram presos a um horário marcado em uma sala de aula. Assim, a assistência da equipe CECEMCA na plataforma Teleduc, possibilitou a interação entre o grupo, através de suas ferramentas. 
Alguns aspectos negativos também foram levantados durante o curso semi-presencial, como a falta de suporte tecnológico das escolas, pois muitas delas, não possuem computadores e Internet. Foi sugerido que o tenha um maior período para sua realização, pois assim os professores teriam mais tempo para trabalhar as ações nas escolas envolvidas, teriam mais tempo para as pesquisas, reflexões e aplicação das atividades.

Um professor demonstrou a necessidade de ter uma pessoa de apoio na mesma cidade de realização do curso para esclarecimento de dúvidas de maneira presencial. 


\section{CONSIDERAÇÕES FINAIS}

Neste trabalho procurou-se analisar a importância da formação de professores, em geral, e da tecnologia, em especial, levando-se em consideração o ensino-aprendizagem, incluindo toda a prática profissional vivenciada. Nesta análise, a formação é encarada como um processo permanente integrado no dia-a-dia dos professores e das escolas, sendo assim, o processo de tornar-se professor é infindável e dinâmico, iniciando-se na formação básica e se estendendo para além dela, durante todo o seu caminho profissional dentro e fora de aula. Neste contexto, a ênfase das políticas sobre a formação de professores expande-se para o rendimento escolar dos alunos e implica em um compromisso com a aprendizagem daquele que ensina. Esta pesquisa incorpora o docente como sujeito que tem uma participação ativa nos planos e programas de políticas públicas, exigindo esforços sistemáticos e sustentáveis concernentes à própria concepção de aprendizagem. O desafio consistiu em pensar uma formação integral, orientada para a reflexão crítica, a identificação e soluções de problemas, a procura de investigar e aprender a ensinar, e a não se concentrar apenas na transferência de conteúdo. O resultado da avaliação tanto do curso presencial como do módulo a distância demonstra que a formação continuada de professores tendo como referência o caderno "Áreas Verdes" apresenta o intenso diálogo reflexivo e aprofundado intercalado com discussões da realidade local.

O curso presencial apresentou bons resultados e mostrou a possibilidade de se estimular uma visão crítica e reflexiva de todos os participantes para trabalhar com o conteúdo do caderno “Áreas Verdes” a partir de sua própria realidade.

No curso a distância, a utilização da plataforma virtual Teleduc foi satisfatória, permitindo uma integração dos professores e uma análise aprofundada das questões ambientais da comunidade local.

O interesse pelo tema "Áreas Verdes" demonstrado por meio dos registros e oficinas elaborados durante o curso, propiciaram a formação de agentes multiplicadores do conteúdo e desenvolveram uma visão crítica capaz de coordenar e avaliar os grupos de estudo. 


\section{REFERÊNCIAS}

ASSOCIAÇÃO DO MUNICÍPIO DO LAGO DE FURNAS. Apresentação. 2009. Disponível em: <http://www.alago.org.br> Acesso em 20 jun 2008.

ALMEIDA, M. E. de. Proinfo: informática e formação de professores. Brasília: Ministério da Educação, Secretaria de Educação a Distância, 2000. v.2 (Série de Estudos. Educação a Distância).

ALONSO, K. M. A avaliação e a avaliação na educação à distância: Algumas notas para reflexão. In: PRETI, Oresti (Org.). Educação a Distância: Sobre discursos e práticas. Brasília: Líber Livro Editora, 2005. p. 153-169.

ALVES, J. R. M. Administração da educação à distância. Rio de Janeiro: Instituto de Pesquisas Avançadas em Educação, 1999.

ALVES, N. Trajetórias e Redes na Formação de Professores. Rio de Janeiro: DP\&, 1998.

AMOR, D. A (R)evolução do e-business. São Paulo, Makron Books, 2000.

ARETIO, L. G. Educación a distancia hoy. Madrid: UNED, 1994.

AUTHIER, M. Le bel avenir du parent pauvre. In Apprendre à distance. Lê Monde de L'Éducation, de la Culture et de la Formation - Hors-série - France, Septembre, 1998. In: BRASIL. MINISTÉRIO DA EDUCAÇÃO SECRETARIA DE EDUCAÇÃO A DISTÂNCIA. Brasília, $2000 . \quad$ Disponível em: http://www.pr5.ufrj.br/curso_distancia/legislacao/Indicadores_de_Qualidade_do_MEC.pdf. Acesso em 05 de julho de 2007.

BARTAlini, V. Áreas verdes e espaços livres urbanos. In: Paisagem Ambiente Ensaios. São Paulo n.1. p 49-54, set. 1986.

BELLONI, M. L. Educação a distância. Campinas, SP: Autores Associados, 1999.

BOFF, L. A águia e a galinha: uma metáfora da condição humana. 29. ed. Petrópolis: Vozes.1999.

BRASIL, Instituto Brasileiro de Geografia e Estatística. Cities@. Disponível em http:// http://www.ibge.gov.br/cidadesat/topwindow.htm?1. Acesso em 20 de maio de 2009.

BRASIL, Ministério da Educação. Disponível em http://portal.mec.gov.br/seb/. Acesso em 05 de agosto de 2007.

Ministério da Educação. Secretaria de Educação à Distância. Programa de Formação de Professores em Exercício. Brasília, 2007. Disponível em: http://proformacao.proinfo.mec.gov.br/. Acesso em 05 de agosto de 2007.

,Ministério da Educação. Casa Civil Subchefia para Assuntos Jurídicos. DECRETO nº. 2.561, DE 27 DE ABRIL DE 1998: Altera a redação dos Artigos. 11 e 12 do Decreto n. ${ }^{\circ}$ 2.494, de 10 de fevereiro de 1998, que regulamenta o disposto no art. 80 da Lei n. ${ }^{\circ}$ 9.394, de 
20 de dezembro de 1996. Brasília, 1998. Disponível em: http://portal.mec.gov.br/sesu/arquivos/pdf/dec2561.pdf. Acesso em 07 de agosto de 2007.
Ministério
da Educação.
Casa
Civil

Subchefia para Assuntos Jurídicos. LEI 9.394/1996: Estabelece as diretrizes e bases da educação nacional. $\quad$ Brasília. $1996 . \quad$ Disponível em: https://www.planalto.gov.br/ccivil_03/Leis/L9394.htm. Acesso em: 07 de agosto 2007.

Ministério do Meio Ambiente. Subchefia para Assuntos Jurídicos. Lei 6.938/81: Dispõe sobre a Política Nacional do Meio Ambiente, seus fins e mecanismos de formulação e aplicação, e dá outras providências. Brasília, 1981. Disponível em: http://www.planalto.gov.br/ccivil_03/Leis/L6938org.htm. Acesso em 07de julho de 2007.

. Ministério do Meio Ambiente. Subchefia para Assuntos Jurídicos. Lei no 9.795, DE 27 DE ABRIL DE 1999: Dispõe sobre a educação ambiental, institui a Política Nacional de Educação Ambiental e dá outras providências. Brasília, 1999. Disponível em: http://www.planalto.gov.br/ccivil_03/Leis/L6938org.htm. Acesso em 07de julho de 2007.

Ministério da Educação. Secretaria de Educação Infantil e Fundamental. EDITAL N. ${ }^{\circ}$ 01/2003-SEIF/MEC. 2003.

Ministério do Meio Ambiente. Subchefia para Assuntos Jurídicos. DECRETO No 5.622, DE 19 DE DEZEMBRO DE 2005: Regulamenta o art. 80 da Lei no 9.394, de 20 de dezembro de 1996, que estabelece as diretrizes e bases da educação nacional. Brasília, 2005a. Disponível em: http://portal.mec.gov.br/seed/arquivos/pdf/dec_5622.pdf. Acesso em 07de julho de 2007.

Rede Nacional de Formação Continuada de Professores de Educação Básica Orientações Gerais/Centro de Pesquisa e Desenvolvimentoda Educação - Catálogo 2006. Brasília: MEC/SEB, $2006 . \quad$ Disponivel em: http://portal.mec.gov.br/seb/arquivos/pdf/Rede/catalg_rede_06.pdf. Acessado em: 21/08/2007.

Rede Nacional de Formação Continuada de Professores de Educação Básica Orientações Gerais - Catálogo 2005. Brasília: MEC/SEB, 2005b. p.42.

BUARQUE; S. C. Metodologia de Planejamento do Desenvolvimento Sustentável. Recife: IICA, 1994.

CALLENBACH, E. Ecologia: Um guia de bolso. Tradução de Dinah de Abreu Azevedo. São Paulo: Editora Fundação Peirópolis, 2001.

CARLOS, A. F. A. A Cidade. São Paulo: Contexto, 1992. (Coleção repensando a geografia).

CARVALHO, I. C. Educação ambiental crítica: nomes e endereçamentos da educação. In: LAYRARQUES, P. P. (coord.) Identidades da educação ambiental brasileira. Brasília: Ministério do Meio Ambiente, Diretoria de Educação Ambiental, 2004. 156p.

CASTRO, C.M.; GUARANYS, L.O. O ensino por correspondência: uma estratégia do desenvolvimento educacional no Brasil. Rio de Janeiro: Manuscrito, 1977. 
CECEMCA. Centro de Educação Continuada em Educação Matemática, Científica e Ambiental. 2005. Disponível em: http://cecemca.rc.unesp.br/cecemca/rnfc/rnfc_centros.htm. Acesso dia 23/09/2007. Acesso em 03 de julho de 2007.

CENTRO DE EDUCAÇÃO CONTINUADA EM EDUCAÇÃO MATEMÁTICA, CIENTÍfICA E AMBIENTAL. Relatório de Atividades PTA 2006. Rio Claro, 2007.

CENTENO, J. A. S.; ANTUNES, A. F. B.; TREVIZAN, S.; CORREA, F. Mapeamento de áreas impermeáveis usando uma metodologia orientada a regiões e imagens de alta resolução. Revista Brasileira de Cartografia, Rio de Janeiro, v.55, n.1, p. 48-56, nov. 2003.

CENTRO DE ESTUDOS E PESQUISAS EM EDUCAÇÃO, CULTURA E AÇÃO COMUNITÁRIA - (CENPEC). Ensinar com a internet: como enfrentar o desafio. Coleção Educarede - internet na escola. Vol.2 2006. Disponível em: http://www.cenpec.org.br/memoria/uploads/F404_138-05-00006volume_II_web.pdf. Acesso em 25 de agosto de 2007.

CERNY, R.Z. Avaliação da aprendizagem na educação à distância. Florianópolis, 2001. 104 p. Dissertação (Mestrado em Educação) - Programa de Pós Graduação em Educação, Universidade Federal de Santa Catarina.

CHEONG, C. S. E-learning - a provider's prospective. Internet and Higher Education, 2002, v.4, p.337-352.

CNBB. Movimento de Educação de Base. Brasília, 2007. Disponível em: http://www.meb.org.br/. Acesso em 05 de agosto de 2007.

CUNHA, L. A.; GÓES, M. de - O Golpe na Educação. Rio de Janeiro: Jorge Zahar, 1985 (Coleção Brasil: os anos de autoritarismo).

DE LUCA, R. R. Educação a distância: ferramenta sob medida para ensino corporativo. In: CONGRESSO DA ASSOCIAÇÃO BRASILEIRA DE EDUCAÇÃO A DISTÂNCIA, (7), 2002, São Paulo. Anais... São Paulo, Abed, 2002.

DETZEL, V. A. Arborização urbana: importância e avaliação econômica. CONGRESSO BRASILEIRO SOBRE ARBORIZAÇÃO URBANA, 1.; ENCONTRO NACIONAL SOBRE ARBORIZAÇÃO, 4., 1992, Vitória. Anais... Vitória: Prefeitura Municipal de Vitória, 1992. p.39-52.

DWYER, F.; McPHERSON, E.G.; SCHOEDER, H.W.; ROWNTREE, R.A. Assessing the benefits and costs of the urban forest. Journal of Arboriculture, Illinois, v.18, n.5, p. 227234, Set.1992.

FERRY, G. Le Trajet de la Formacion. Lês Enseignants entre la Téorie et la Pratique. Paris. Dunod. 1983. In: SILVA, M. O. E. A Análise da Necessidade de Formação na Formação Contínua de Professores: Um Caminho para a Integração Escolar. Tese de Doutorado. Faculdade de Educação da Universidade de São Paulo, 2000. 
FIEN, J. \& RAWLING, R. Reflective Practice: a case study of professional development for environmental education. The Journal of Environmental Education, 27, 3, p.11-20. 1996.

FUNDAÇÃO ROBERTO MARINHO. Telecurso 2000. Disponível em: http://www.frm.org.br/main.asp. Acesso em 05 de agosto de 2007.

GARCÍA, C. M. A formação de professores: centro de atenção e pedra-detoque. In: NÓVOA, A. (Coord.) Os professores e a sua formação. Lisboa: Publicações D. Quixote, 1995. 2.ed. p.51-76.

GIMENO, S. J. Educar e conviver na cultura global: as exigências da cidadania. Porto Alegre: Artes Médicas, 2002.

GONZAGA, J. L. Educação Ambiental nas bacias hidrográficas de Ibaté - SP e região, envolvendo o ensino formal: uma visão pedagógica do processo. 2003. 142p. Dissertação (Mestrado) - Escola de Engenharia de São Carlos, Universidade de São Paulo. 2003.

GOTTSCHALK, T.H. Distance Education and www. 2002. Disponível em: <http://www.uidaho.edu/evo/dist11.html> Acesso em: 17 de agosto de 2006.

GOUVÊA, G. R. R. Rumos da formação de professores para a Educação Ambiental. Educar, Curitiba, Editora UFPR, 2006. n. 27, p. 163-179.

GREENSTEIN, M.; FEINMAN, T. Electronic commerce: security, risk management and control. Boston: McGraw-Hill, 2000. 400p.

GREY, G. W.; DENEKE, F J. Urban forestry. New York: John Wiley, 1978.

GUIMARÃES, M. Educação ambiental crítica. In: LAYRARQUES, P. P. (coord.) Identidades da educação ambiental brasileira. Brasília: Ministério do Meio Ambiente, Diretoria de Educação Ambiental, 2004. 156p.

HÄMÄLÄINEN, M.; WHISNSTON, A. B; VISHIK, S. Electronic markets for learning: education brokerages on the internet. Communications of the ACM, New York, v.39, n.6, p.51-58, jun.1996.

HARDER, I. C. F. Inventário quali-quantitativo da arborização e infra-estrutura das praças da cidade de Vinhedo (SP). 2002. 122p. Dissertação (Mestrado em Fitotecnia) Escola Superior de Agricultura "Luiz de Queiroz", Universidade de São Paulo, Piracicaba, 2002.

HASUI, E.; RAMOS, F. N.; SILVA, V. X. Caracterização da fragmentação florestal na mata atlântica estacional no sul de Minas Gerais e suas conseqüências bióticas e abióticas. Alfenas: UNIFAL, 2009. Apresenta projeto de pesquisa. Disponível em: http://www2.unifal-mg.edu.br/ecofrag/?q=projetos. Acesso em 28 jun 2009.

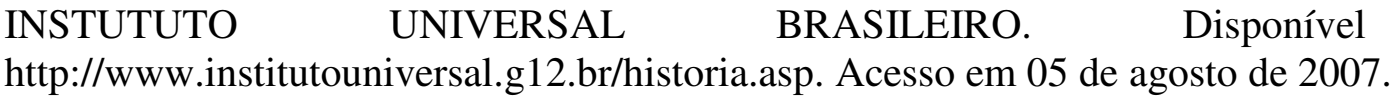


KATZ, H.H. A state of the art on the independent private School industry in the state of Illinois. Advisor Council on Vocational Education, May, 1973, p.6-7.

KEEGAN, D. Foundations of Distance Education. New York: Routledge, 1996, 3.ed.

KENSKI, V. M. Novas tecnologias na educação presencial e a distância. In: ALVES, L.; NOVA, C. (Org.) Educação a distância: uma nova concepção de aprendizado e interatividade. São Paulo: Futura, 2003b, p. 25-42.

V. M. Tecnologias e ensino presencial e a distância. Campinas: Papirus, 2003a. (Série Prática Pedagógica).

LANDIM, C. M. das M. P. F.. Educação a Distância: algumas considerações. Rio de Janeiro: [s.n.], 1997, 146p.

LAUDON, K. C.; LAUDON, J. P. Gerenciamento de sistemas de informação. Rio de Janeiro: LTC, 2001.

LEFF, E. Saber ambiental: sustentabilidade, racionalidade, complexidade, poder. Petrópolis: Vozes, 2001.

LEITE, D. N. A. De O. Desenvolvimento de material didático para as primeiras séries do Ensino Fundamental: subsídio à educação ambiental. 2008. 2 v. Tese de Doutorado (Doutorado em Geografia) - Instituto de Geociências e Ciências Exatas, Universidade Estadual Paulista, Rio Claro, 2008.

LÉVYI, S. Six factors to consider when planning online distance learning programs in higher education. 2003. Disponível em: <http:/www.westga.edu/\%Edistance/ojdla/ spring61/levy61.htm> Acesso em: 06 de setembro de 2006.

LITWIN, E. (org.). Educação à distância. Porto Alegre: Artmed, 2001.

LOMBARDO, M. A. Vegetação e clima. In: ENCONTRO NACIONAL SOBRE ARBORIZAÇÃO URBANA, 3., 1990, Curitiba. Anais... Curitiba: FUPEF; UFPR, 1990. p. $1-13$.

LOMBARDO, M. A.; LOURENÇO, J. M. R. M. F.; VOLPE, L. L. A vegetação arbórea urbana e seus reflexos na qualidade ambiental urbana: o caso da cidade de Alfenas - MG. Anais... In: Seminário da Pós Graduação em Geografia da Unesp. VII, Rio Claro, 2007.

LÜDKE, M; ANDRÉ, M. E.D.A. Pesquisa em educação: abordagens qualitativas. São Paulo: EPU, 1986.

MAGALHAES, M. G. de M. Metodologia para a integração de novas tecnologias na formação de professores. 2004. 148p.Tese (Doutorado em Ciências) - Instituto de Física de São Carlos, Universidade de São Paulo, São Carlos, 2004.

MARCELO, C. G. Formación del profesorado para el cambio educativo. Barcelona: EUB, 1999. $2^{a}$ ed. 
MARQUES, M. O. A formação do profissional de educação. Ijuí: Editora: Unijuí, 2003. 4 ed.

McPHERSON, E. G. Accounting for benefits and costs of urban green space. Landscape and Urban Planning, Amsterdam, v. 22, n.1, p. 41-51, 1992.

McPHERSON, E.G.; SIMPSON, J. R. A comparison of municipal forest benefits and costs in Modesto and Santa Monica, California, USA. Urban Forestry \& Urban Green, Davis, n.1, p.61-74, 2002.

MELLO FILHO, L. E. Arborização urbana. In: ENCONTRO NACIONAL SOBRE ARBORIZAÇÃO, 1., 1985, Porto Alegre. Anais... Porto Alegre: Prefeitura Municipal de Porto Alegre; Secretaria Municipal do Meio Ambiente, 1985. p.117-127.

MILANO, M.S.; DALCIN, E. C. Arborização de vias públicas. Rio de Janeiro: Light, 2000. $226 \mathrm{p}$.

MIZUKAMI, M. da G. N.; et al. Escola e aprendizagem da docência: processos de investigação e formação. São Carlos: EDUFSCar, 2003.

MONTEIRO, D. C.; GIOVANNI, L. M. Formação continuada de professores: o desafio metodológico. In: MARIN, A. J. (Org.) Educação continuada: reflexões, alternativas. Campinas: Papirus, 2000. p.129-143 (Coleção Magistério: Formação e Trabalho Pedagógico).

MOORE, M.; KEARSLEY, G. Distance education: a systems view. Belmont (USA), CA: Wadsworth Publishing Company, 1996.

MORAN, J. M. O que é educação à distância. 2005. Disponível em: http://www.eca.usp.br/prof/moran/dist.htm. Acesso em: 29 maio 2007.

NEDER, M. L. C. A educação à distância e a formação de professores: Possibilidades de mudança paradigmática. In: PRETI, Oresti (Org.). Educação a Distância: Sobre discursos e práticas. Brasília: Líber Livro Editora, 2005. p. 47-87.

NEVES, C. M. de C. A Educação à distância e a Formação de Professores. Disponível em: $<$ http://www.tvebrasil.com.br/SALTO/boletins2002/EaD/EaDtxt1a.htm> Acesso em 11 de agosto de 2007.

NIPPER, S Third Generation Distance Learnig and Computer Conference. In: MASON, R.; KAYE, A. In: Mindwave: Communication, Computers and Distance Education. Oxford: Pergamon Press, 1989. Cap. 5, p.63-73.

NISKIER, A. Educação a distância: a tecnologia da esperança. São Paulo: Loyola, 1999.

NOVA, C.; ALVES, L. Educação à distância: limites e possibilidades. In: ALVES, L.; NOVA, C. (Org.) Educação à distância: uma nova concepção de aprendizado e interatividade. São Paulo: Futura, 2003. p.1-23.

NÓVOA, A. Formação de professores e profissão docente. In: NÓVOA, A. (Coord.) Os professores e a sua formação. Lisboa: Publicações D. Quixote, 1995. 2.ed, p.13-33. 
1992.

A. Os professores e a sua formação. Lisboa, Portugal: Publicações Dom Quixote,

NOWAK, D.J.; McPHERSON, E.G. Quantifying the impact of trees: the Chicago urban forest climate project. Unasylva, Rome, v.44, n.173, p. 39-44, 1993.

NUNES, I. B. Modalidades educativas e novas demandas por educação. 2001. Disponível em: <http://www.intelecto.net/EaD/modalidades.htm> Acesso em: 21 out. 2006.

OLIVEIRA, H. T. Potencialidades do uso educativo do conceito de bacia hidrográfica em programas de EA. In: SCHIAVETTI, A. \& CAMARGO, A.F.M. (eds.) Conceito de Bacias Hidrográficas: teoria e aplicações. Ilhéus: Editora EDITUS/UESC, 2002. p. 125-139

OLIVEIRA, I. E. A. Didática do ensino superior. In: MARTINS, O. (org.). Curso de Formação em educação à distância: Metodologia da Pesquisa e Didática do Ensino Superior. Módulo 5, MEC:UniRede, 2001. p.89-139.

PAIVA, H.N.; GONÇALVES, W. Florestas urbanas: planejamento para melhoria da qualidade de vida. Viçosa: Aprenda Fácil, 2002. 180 p. (Série Arborização Urbana, 2).

PALLOFF, R. M.; PRATT, K. Building Learning Communities in cyberspace. São Francisco, CA: Jossey-Bass Publishers, 1999.

PIZZOL, K. M. de A. A dinâmica urbana: uma leitura da cidade e da qualidade de vida no urbano. Caminhos de Geografia-revista on line, Uberlândia, v.1, n.17, p.1-7, fev.2006. Disponível em: <http://www.ig.ufu.br/revista/caminhos.html>. Acesso em: 03 junho de 2007.

PORTO, Y. da S. Formação continuada: a prática pedagógica recorrente. In: MARIN, A. J. (Org.) Educação continuada: reflexões, alternativas. Campinas: Papirus, 2000. p.11-37. (Coleção Magistério: Formação e Trabalho Pedagógico)

PRETI, O. (Org.). Educação a Distância: Sobre discursos e práticas. Brasília: Líber Livro Editora, 2005.

O. et al. História da educação à distância. In: MARTINS, O. (org.). Curso de Formação em Educação a Distância: fundamentos e políticas de educação e seus reflexos na educação a distancia. Módulo 1. MEC: UniRede, 2001. p.81-178.

PRICE, C. Quantifyning the aesthetic beneficts of urban forestry. Urban Forestry \& Urban Greening, Davis, v.1, n.3, p. 123-133, 2003.

REIGOTA, M. O que é Educação Ambiental. São Paulo: Brasiliense, 1994, 62 p.

RODRIGUES, A.; ESTEVES, M. A Análise de Necessidades na Formação de Professores. Porto: Porto Editora, col. Ciências da Educação. 1993.

RODRIGUES, G. De uvb.Br a iuv.Br: O desafio de formar uma rede virtual de universidades. In: MAIA, Carmem. Guia brasileiro de educação a distância. São Paulo: Esfera, 2002. p3354. 
ROSENBERG, M. J. E-learning: estratégia para a transmissão do conhecimento na era digital. São Paulo: Makron Books, 2002.

SÁ CARNEIRO, A. R.; MESQUITA, L. B. Espaços Livres do Recife. Recife: Prefeitura da Cidade do Recife/ Universidade Federal de Pernambuco, 2000.

SALAS, E.; KOSARZYCKI, M. P.; BURKE, C. S.; FIORE, S. M.; STONE, D. L. Emerging themes in distance learning research and practice: some food for thought. International Journal of Management Review, Orlando, v.4, n.2, p.135-153.

SANTOS, C. N. Dizei-me cidade brasileira se alguma arquitetura há tão bela e tão altaneira? In: Revista Projeto, São Paulo, n.53, p36-42, jul.1983.

SANTOS, E. Caracterização dendrológica e estética de 18 espécies arbóreas com potencial de uso em paisagismo e arborização urbana. 1994. 146f. Dissertação (Mestrado em Ciência Florestal) - Universidade Federal de Viçosa, Viçosa, 1994.

SANTOS, M. Os Deficientes Cívicos. 2000. Disponível em: $<$ http://www1.folha.uol.com.br/fol/brasil500/dc_3_9.htm>. Acesso em 07 de novembro de 2006.

SARAIVA, T. Educação a distância no Brasil: lições da história. Em Aberto, Brasília, DF, ano16, n.70, p.28-33. abr/jun. 1996.

SATTLER, M. A. Arborização urbana e conforto ambiental. In: CONGRESSO BRASILEIRO DE ARBORIZAÇÃO URBANA, 2.; ENCONTRO NACIONAL SOBRE ARBORIZAÇÃO URBANA, 5., 1994, São Luís. Anais... São Luís: Prefeitura Municipal de São Luís, 1994. p.15-28.

SÉ, J. A. S. Educação Ambiental nas bacias hidrográficas do Rio do Monjolinhoe do Rio Chibarro: Ciência, Educação e Ação nos Quotidianos de São Carlos e Ibaté (SP). 1999. 254p. Tese (Doutorado). Escola de Engenharia de São Carlos, Universidade de São Paulo. São Carlos, 1999.

SHULMAN, C.H. Instructional television-Higher education without commercial interruption. American Association for Higher Education, May, 1981, p.33.

SILVA, M. O. E. A Análise da Necessidade de Formação na Formação Contínua de Professores: Um Caminho para a Integração Escolar. Tese de Doutorado. Faculdade de Educação da Universidade de São Paulo, 2000.

SOARES, L. F. G. et al. Redes de Computadores: das LANs, MANs e WANs às Redes ATM. 2. Ed. Rio de Janeiro: Campus, 1995.

STRAZZO, D.; WENTLING, T. L. A study of e-learning practices in selected Fortune 100 companies. The Knowledge and Learning System Group/The NCSA e-learning group University of Illinois, 2000. 
TAPSCOTT, D.; CASTON, A. Paradigm shift: the new promise of information technology. New York : McGraw-Hill, 1993

TARDIF, M. Saberes docentes e formação profissional. Petrópolis: Vozes, 2002. $4^{\mathrm{a}}$ ed.

TAVARES, F. J. P. A Educação Ambiental na formação de professores de Educação Física: uma emergente conexão. Revista Digital - Buenos Aires - Año 9 - $\mathrm{N}^{\circ} 61$ - Junio de 2003. Disponível em: http://www.efdeportes.com/. Acesso em 17 de maio de 2007.

TILBURY, D. Environmental Education within preservice teacher education: the priority of priorities. International Journal of Environmental Education and Information. 11, 4, pp.267-280.1992.

TÓRO-TONISSI, R. M. (2005). Percepção e caracterização ambientais da área verde da microbacia do córrego da Água Quente (São Carlos, SP) como etapas de um processo de Educação Ambiental. Tese (Doutorado) - Escola de Engenharia de São Carlos, Universidade de São Paulo, São Carlos.

TORRES, C. A. A Universidade Aberta de Brasília. 1994. Disponível em: <http://www.intelecto.net/EaD_textos/carlos1.html> Acesso em 29 out. 2006.

UNIVERSIDADE DE SÃO PAULO. Disponível em: http://www.icmc.usp.br/ensino/material/html/intro.html. Acesso em 28 de agosto de 2007.

UNIVERSIDADE ESTADUAL DE CAMPINAS - UNICAMP. Disponível em: http://teleduc.nied.unicamp.br/pagina/offline.php?usuario=2147483648. Acesso em 06 de agosto de 2007.

UNIVERSIDADE FEDERAL DO RIO GRANDE DO NORTE (UFRN). Departamento de Informática $\mathrm{e}$ Matemática Aplicada. Disponível em: http://www.dimap.ufrn.br/ jorge/textos/introdutorios/oqueehsoftware.html. Acesso em $27 \mathrm{de}$ agosto de 2007.

URDAN, T. A.; WEGGEN, C. C. Corporate e-learning: exploring a new frontier. Março $2000 . \quad$ Disponível em: $<$ http://wrhambrecht.com/research/coverage/elearning/ir/ir_explore.pdf $>$. Acesso em: $17 \mathrm{de}$ out. de 2006.

VASSOS, T. Marketing estratégico na interne t. São Paulo: Makron Books, 1997.

VEIGA, R. T.; MOURA, A. I.; GONÇALVES, C. A.; BARBOSA, F. V. O ensino à distância pela internet: conceito e proposta de avaliação. In: ENCONTRO NACIONAL DA ANPAD, (22), 1998, Foz do Iguaçu. Anais... Foz do Iguaçu: ANPAD, 1998.

WENTLING, T.L.; WAIGHT, C.; GALLAHER, J.; LA FLEUR, J.; WANG, C.; KANFER, A. The Knowledge and Learning System Group. Elearning-A review of literature, Illinois: NCSA elearning group University of Illinois, p.1-73, set.2000. Disponível em: $<$ http://learning.ncsa.uiuc.edu/papers/elearnlit.pdf>. Acesso em: Agosto 2007. 
ZEVI, B. Saber ver a Arquitetura. Tradução Maria Isabel Gaspar e Gaëtan Martins de Oliveira. São Paulo: Martins Fontes, 1978. 
ANEXO A 
FORMULÁRIO DE AVALIAÇÃO DO CURSO POR PARTE DOS PARTICIPANTES

\section{ÁREAS VERDES}

ALFENAS E REGIÃO

Coordenador de grupo de estudos ( )

Professor Participante ( )

1. Como você avalia o curso? (®) Ótimo

( ) Bom

( ) Regular

( ) Fraco

2. O Curso atendeu às suas expectativas?

( ) Sim, superou o esperado

(\&) Sim, atendeu plenamente

( ) Sim, atendeu parcialmente

( ) Não atendeu

3. Como você avalia as aulas ministradas? (kc) Ótimas

(c) Boas

( ) Regulares

( ) Fracas

4. Manifeste sua opinião a respeito do conteúdo.

(๘) Ótimo

( ) Bom

( ) Regular

( ) Fraco

5. Você recomendaria este curso a outra pessoa?

(o) $\operatorname{Sim}$

( ) Não

6. O Tempo de duração dos cursos foi?

(飞) Satisfatório

( ) Curto

( ) Longo

7. A ação contribuiu para sua formação? Porque?

(x) $\operatorname{Sim}$

( ) Não

Beque houre muita treqca de experièncias

entree todos os mremb́os do grupo be estado

sons) coovedemantore e a diemos brabalfrinom juentor

de torma satispatóreia 
8. O curso apresentou-se articulado em termos de: conteúdo, referencial bibliográfico, organização, interação, trabalhos, discussão, formação de grupo de estudos? Aponte os aspectos positivos e negativos e dê sugestões para o

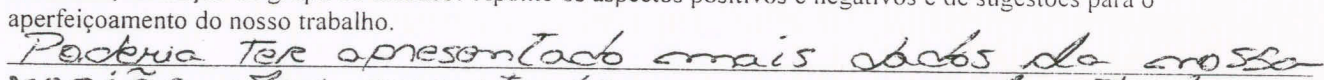

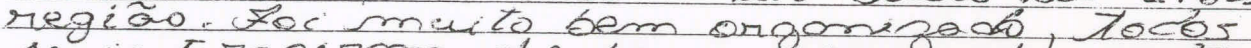
Ne intiragirom de forma resperada des trabal hes

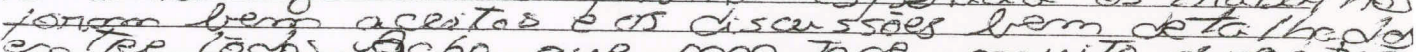

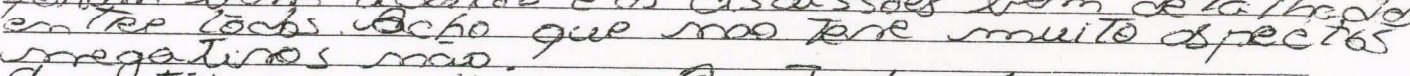

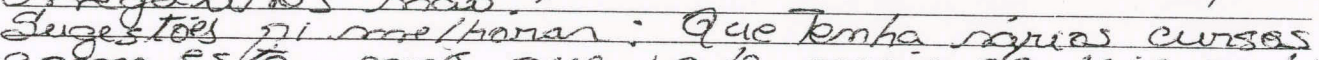
colmo estio, mos que fafe mais de keis smbi-

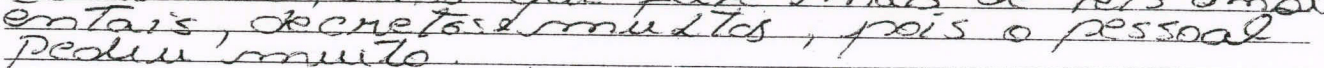

As questões 9 e 10 serão respondidas somente pelos Coordenadores de Grupo de Estudos:

9. Como você avalia seu trabalho junto ao Grupo de Estudos?

๑) Ótimo

( ) Bom

( ) Regular

( ) Fraca

Por que?
Haure muita participacáo de todós dé forma
Satisfatória

10. Como você avalia o uso da Plataforma Teleduc?

(১) Ótimo

( ) Bom

( ) Regular

( ) Fraca

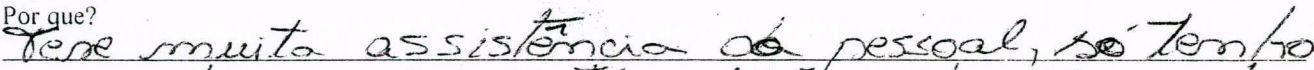

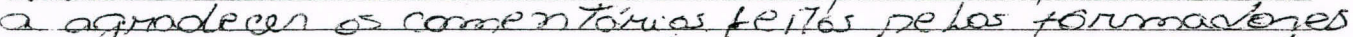

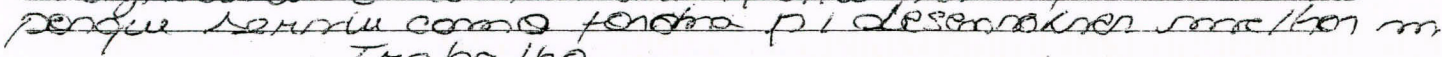
Traba ho

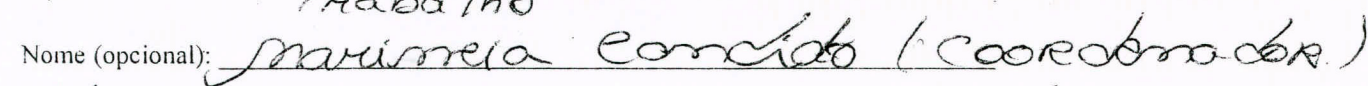

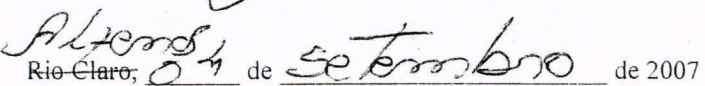

Agrảdecemos a sua colaboração! 


\section{FORMULÁRIO DE AVALIAÇÃO DO CURSO POR PARTE DOS PARTICIPANTES}

\section{ÁREAS VERDES \\ ALFENAS E REGIÃO}

Coordenador de grupo de estudos $(x)$

Professor Participante ( )

1. Como você avalia o curso?

(メ) Ótimo

( ) Bom

( ) Regular

( ) Fraco

2. O Curso atendeu às suas expectativas?

$(メ$ Sim, superou o esperado

( ) Sim, atendeu plenamente

( ) Sim, atendeu parcialmente

( ) Não atendeu

3. Como você avalia as aulas ministradas?

(X) Ótimas

( ) Boas

( ) Regulares

( ) Fracas

4. Manifeste sua opinião a respeito do conteúdo.

( $\chi$ ) Ótimo

( ) Bom

( ) Regular

( ) Fraco

5. Você recomendaria este curso a outra pessoa? (X) Sim

( ) Não

6. O Tempo de duração dos cursos foi? $(\rtimes)$ Satisfatório

( ) Curto

( ) Longo

7. A ação contribuiu para sua formação? Porque?

(X) Sim

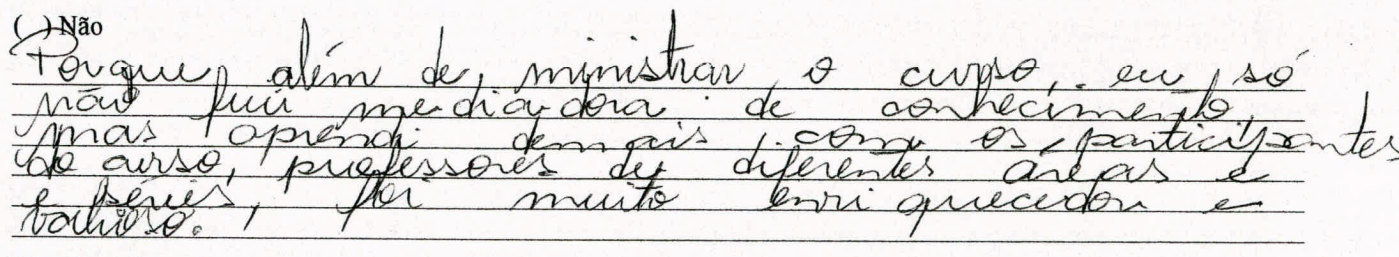

Rua 10, 2527 - CEP 13500-230 - RIO CLARO - SP - Brasil - CX. Postal, 178 


\section{unesp}

Centro de Educação Continuada em Educação

Matemática, Científica e Ambiental

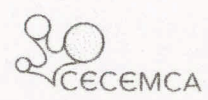

8. O curso apresentou-se articulado em termos de: conteúdo, referencial bibliográfico, organização, interação, trabalhos, discussão, formação de grupo de estudos? Aponte os aspectos positivos e negativos e dê sugestões para o aperfeiçoamento do nosso trabalho.

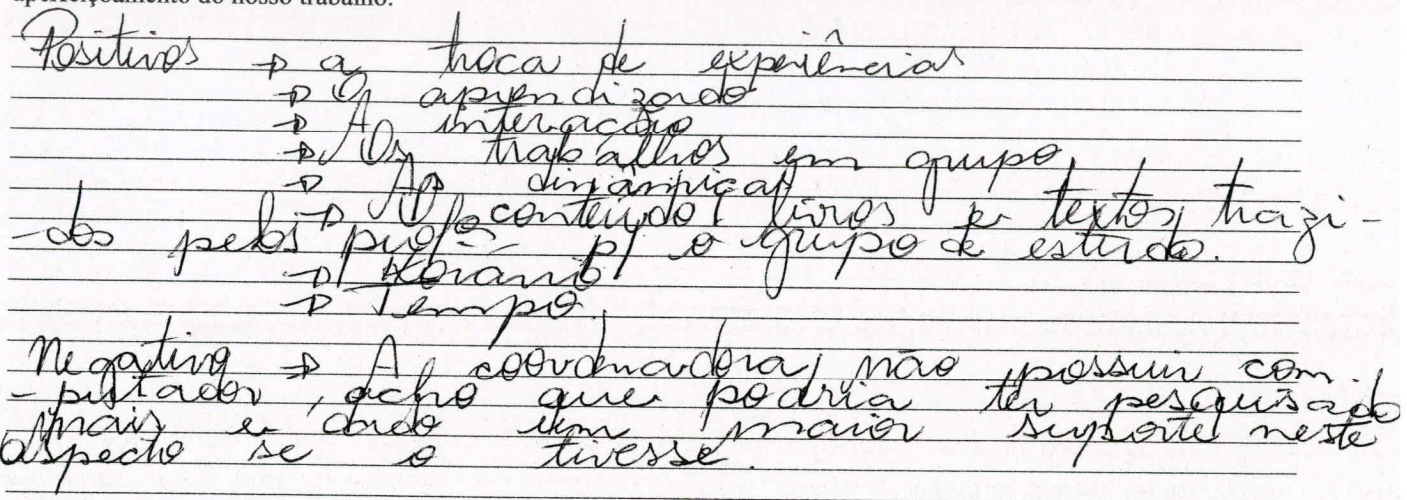

As questões 9 e 10 serão respondidas somente pelos Coordenadores de Grupo de Estudos:

9. Como você avalia seu trabalho junto ao Grupo de Estudos?

( Ótimo

( ) Bom

( ) Regular

( ) Fraca

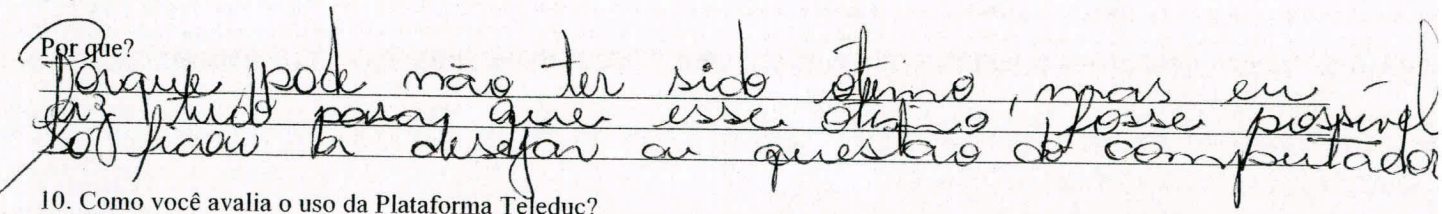

(メótimo

( ) Bom

( ) Regular

( ) Fraca

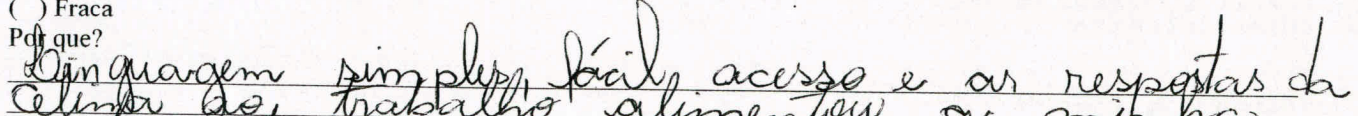

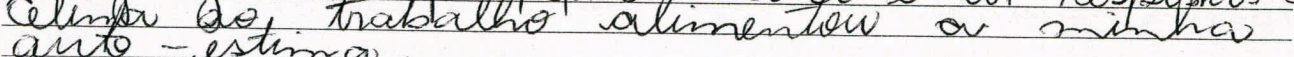

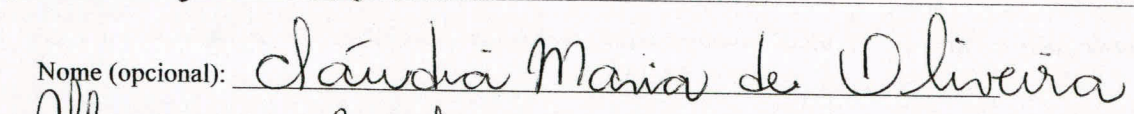

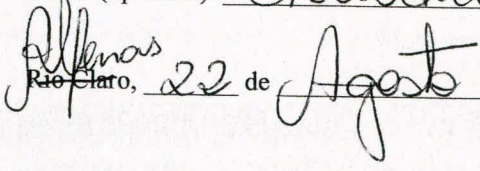
de 2007

Agradecemos a sua colaboração! 


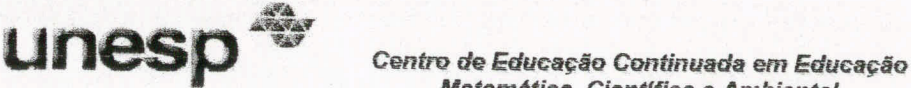 Matemática, Cientfica e Ambiental

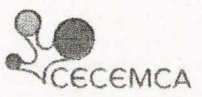

FORMULÁRIO DE AVALIAÇÃO DO CURSO POR PARTE DOS PARTICIPANTES

\section{ÁREAS VERDES \\ ALFENAS E REGIÃO}

Coordenador de grupo de estudos (

Professor Participante ( )

1. Como você avalia o curso?

$\bowtie$ Ótimo

( ) Bom

( ) Regular

( ) Fraco

2. O Curso atendeu às suas expeciativas?

() Sim, superou o esperado

( ) Sim, atendeu plenamente

( ) Sim, atendeu parcialmente

( ) Não atcndeu

3. Como você avalia as aulas ministradas? $(\infty)$ Otimas

( ) Boas

( ) Regulares

( ) Fracas

4. Manifeste sua opinião a respeito do conteúdo. (x) Ótimo

( ) Bom

( ) Regular

( ) Fraco

5. Você recomendaria este curso a outra pessoa?

(メ) Sim

( ) Não

6. O Tempo de duração dos cursos foi?

$($ Satisfatório

() Curto

( ) Longo

7. A ação contribuiu para sua formação? Porque?

(X) Sim

( ) Não

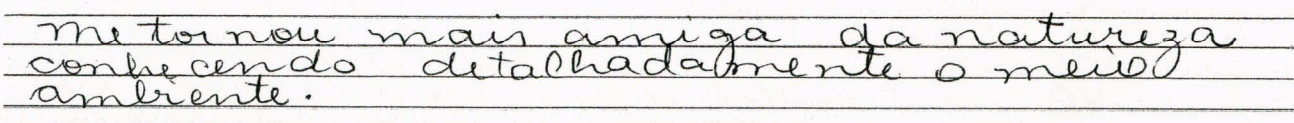
ambiente. 


\section{unesp}

Centro de Educaçäe Continuada em Educação Matematica, Cientifica e Ambiental

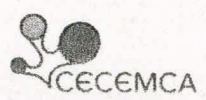

8. O curso apresentou-se articulado em termos de: conteúdo, referencial bibliográfico, organização, interação, trabalhos, discussão, formação de grupo de estudos? Aponte os aspectos positivos e negativos e dê sugestões para o aperfeiçoamento do nosso trabalho.

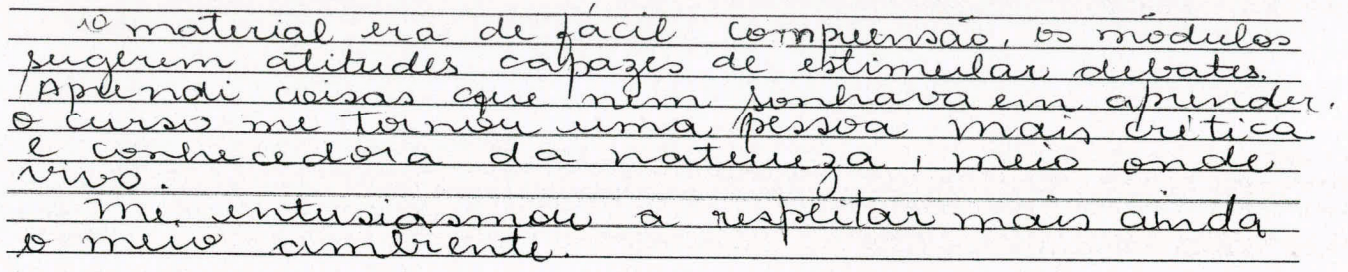

As questões 9 e 10 serão respondidas somente pelos Coordenadores de Grupo de Estudos:

9. Como você avalia seu trabalho junto ao Grupo de Estudos?

(X) Ótimo

() Bom

( ) Regular

( ) Fraca

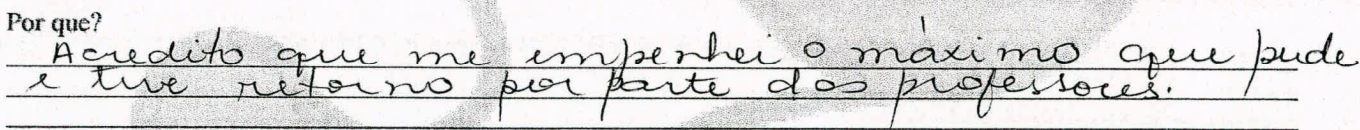

10. Como você avalia o uso da Plataforma Teleduc?

(x) Ótimo

( ) Bom

( ) Regular

() Fraca

Porqué, facil acuss, tudo muito bem explicara e a orientadora portual expetacular.

Nome (opcional)

Rio Claro, 31 de Agusto de 2007

Agradecemos a sua colaboração! 


\section{Lneso \\ Centro de Educação Continuada em Educaçāo Mlaŕemátical, Ciemtífica e Ambiental

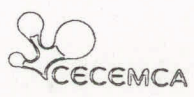

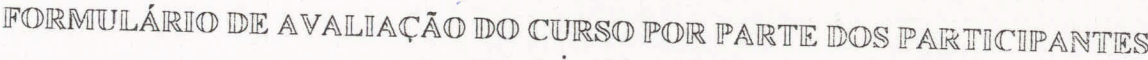

\section{ÁREAS VERDES \\ ALFENAS E REGIÃO}

\section{Coordenador de grupo de estudos $(x)$}

1. Como vecê ar alia o curso"?

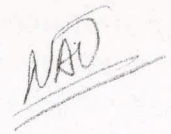

( ) Ótimo

(x) $13 \mathrm{om}$

( ) Regular

() Fraco

2. O Curso atendeu às suas expectativas?

(X) Sim, superou o esperado

( ) Sim. atendeu plenamente

( ) Sim. atendeu parcialmente

( ) Não atendeu

3. Como você avalia as aulas ministradas?

( ) Ótimas

$\times$ Boas

( ) Regulares

( ) Fracas

4. Manifeste sua opinião a respeito do conteúdo

( ) Ótimo

X B Bom

( ) Regular

( ) Fraco

5. Você recomendaria est ${ }^{\wedge}$ curso a outra pessoa?

(メ) Sim

( ) Não

6. O Tempo de duracão dos cursos foi?

( Satisfatório

( ) Curto

( ) Longo

7. A ação contribuiu para sua formação'? Porque?

(X) Sim

( ) Nào

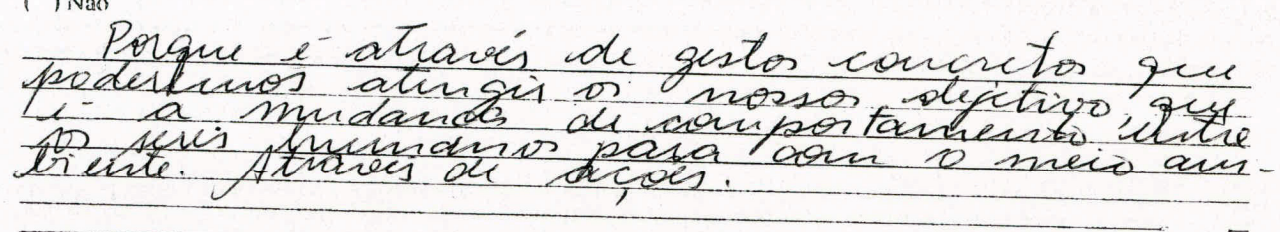

Professor Participante ( ) 


\section{urieso}

Centro de Educação Continuada em Educação âderemática, Científica e Ambiental

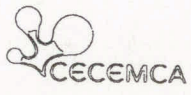

8. O curso apresentou-se articulado em termos de: conteúdo, referencial bibliográfico, organização, interação, trahalhos discussão, formaçầo de grupo de estudos? Aponte os aspectos positivos e negativos e dè sugestòes para o aperfeiçoamento denosso trabalho.

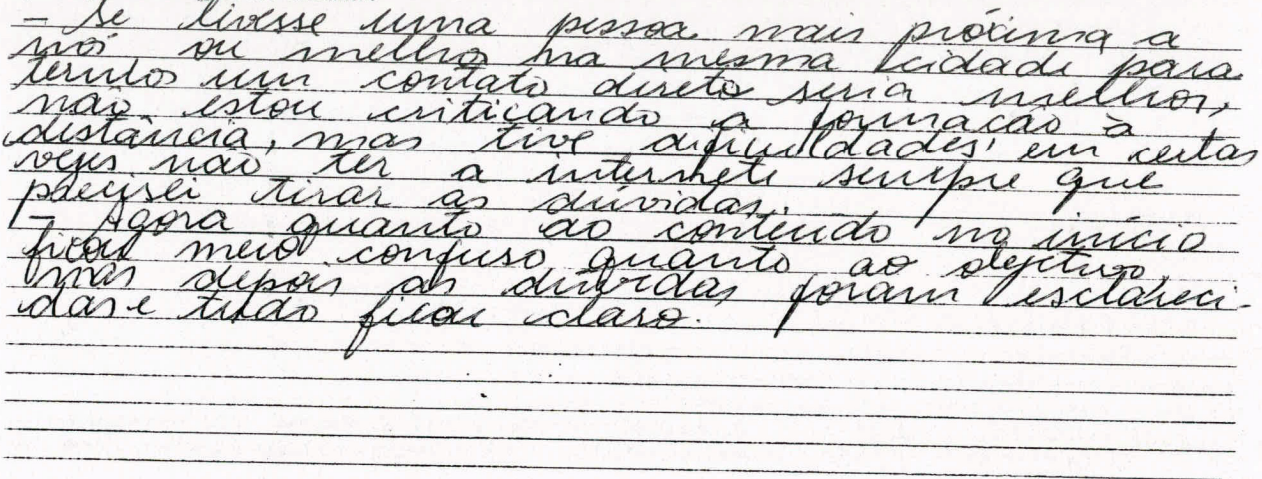

As questões 9 e 10 serão respondidas somente pelos Coordenadores de Grupo de Estudos:

9. Como você avalia seu trabalho junto ao Grupo de Estudos?

(X) Ótimo

() Bom

( ) Regular

( ) Fraca

Porque? participacaio de todos $n$ interesse

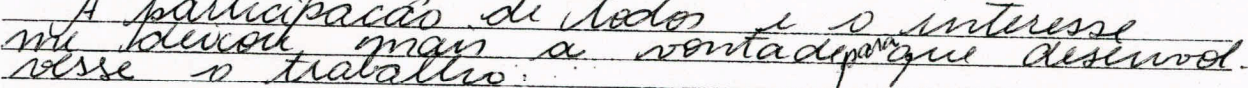

10. Como você avalia o uso da Plataforma Teleduc?

(X) Ótimo

( ) Bom

( ) Regular

( ) Fraca

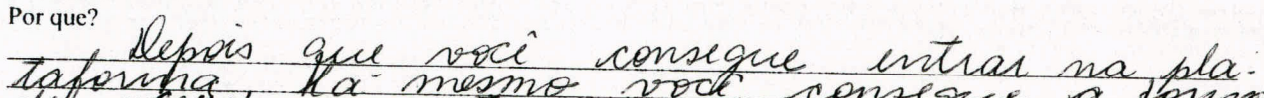

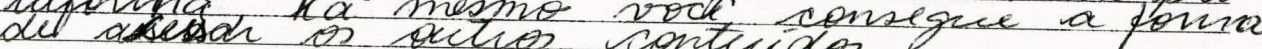

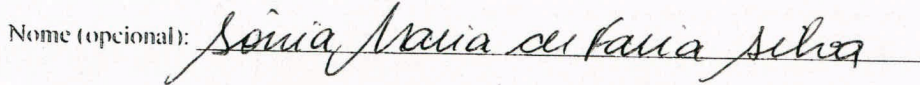

Rio ('lart). seterver de 2007

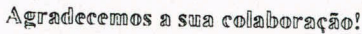




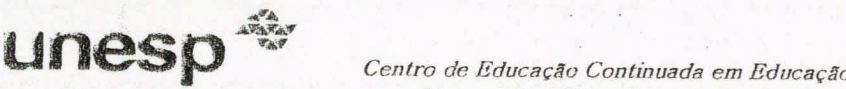 Matemática, Cientffica e Ambiental \\ âa}

FORMULÁRIO DE AVALIAÇÃO DO CURSO POR PARTE DOS PARTICIPANTES

\section{ÁREAS VERDES}

ALFENAS E REGIÃO

\section{Coordenador de grupo de estudos $(x)$}

Professor Participante ( )

1. Como você avalia o curso?

( Ótimo

( ) Bom

( ) Regular

() Fraco

2. O Curso atendeu às suas expectativas?

(メ) Sim, superou o esperado

() Sim, atendeu plenamente

( ) Sim. atendeu parcialmente

( ) Nào atendeu

3. Como você avalia as aulas ministradas?

(x) Ótimas

( ) Boas

() Regulares

( ) Fracas

4. Manifeste sua opiniào a respeito do conteúdo.

( ) Ótimo

(X) Bom

(1) Regular

( ) Fraco

5. Você recomendaria este curso a outra pessoa?

$\bowtie \operatorname{Sim}$

( ) Não

6. O Tempo de duração dos cursos foi?

( $>$ Satisfatório

( ) Curto

( ) Longe

7. A açào contribuiu para sua formaçào? Porque?

( $) \mathrm{Sim}$

( ) Nào

Devemos adotar nãu só a preservaçäo, mas a protecáo e manuteneap,pois, temus so dever de estender a Vida UTil dos TIATamento CorreTo. Formando uma alianea global para 


\section{unesp

8. O curso apresentou-se articulado em termos de: conteúdo, referencial bibliográfico, organização, interação, trabalhos. discussão, formação de grupo de estudos? Aponte os aspectos positivos e negativos e dê sugestões para o aperfeiçoamento do nosso trabalho.

E Fundamental saber que ainda há Tempo! Que é preciso Tes compromisso com a Vida ou entas sesemos responsáveis pela extincáo dz espécie humana. Devemos arregacar as lmangas e Ter a responsabilidade em irelacao a questães de preservacáo e conservaclán de re zursos naturais. 6 lconteudo mostrou a preócu facão em preservar, plantar, semear. Dusan Te Todo - I curso houve interacáo entre os grupos e Asto A $^{\prime}$ gratificante gegativo $\rightarrow 0$ multiplicador Teria que afastar da sala de aula para podev Ter um espaco maior em preparacá. dos Trabaihos (da paluTa) e Também a falta de recursos materiais para que 0 multiplicador possa ter melhores condicoes ex: data-show, a maioria das escolas nas Tem inTernete, xeróx, esta foi nossa dificuldade...

As questòes 9 e 10 serăo respondidas somente pelos Coordenadores de Grupo de Estudos:

9. Como você avalia seu trabalho junto ao Grupo de Estudos?

(メ) Ótimo

( ) Bom

( ) Regular

( ) Fraca

Porque sutesacáo e Socializacáo e muita aprendizagem', Todo o curso 'representou um processo edueativo e repleto de acoes.

10. Como você avalia o uso da Plataforma Teleduc?

(x) Ótimo

( ) Bom

( ) Regular

() Fraca

Por que?

Fui muito bem, atendida, nos deu Todo o suporte necessavio.

Nome (opcional): Marilene Vidili de Oliveisa

Rio Claro, 2」 de Selembro de 2007

Agradecemos a sua colaboração! 


\section{unesp}

Centro de Educação Continuada em Educação

Matemática, Científica e Ambiental

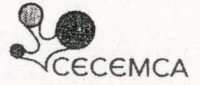

FORMULÁRIO DE AVALIAÇÃo DO CURSO POR PARTE DOS PARTICIPANTES

\section{ÁREAS VERDES}

ALFENAS E REGIÃO

\section{Coordenador de grupo de estudos $(X)$}

Professor Participante ( )

1. Como você avalia o curso?

(X) Ótimo

( ) Bom

( ) Regular

( ) Fraco

2. O Curso atendeu às suas expectativas?

( ) Sim, superou o esperado

(x) Sim, atendeu plenamente

( ) Sim, atendeu parcialmente

( ) Não atendeu

3. Como você avalia as aulas ministradas?

(x) Ótimas

( ) Boas

( ) Regulares

( ) Fracas

4. Manifeste sua opinião a respeito do conteúdo.

(X) Ótimo

( ) Bom

( ) Regular

( ) Fraco

5. Você recomendaria este curso a outra pessoa?

(x) $\operatorname{Sim}$

( ) Não

6. O Tempo de duração dos cursos foii?

( ) Satisfatório

(X) Curto

( ) Longo

7. A ação contribuiu para sua formação? Porque?

(X) $\operatorname{Sim}$

( ) Não curbs now faroporionou conhecimentos impontantus. do unportancia de incluir a intirdisciplindriedade 


\section{unesp}

Centro de Educação Continuada em Educação

Matemática, Científica e Ambiental

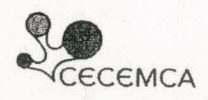

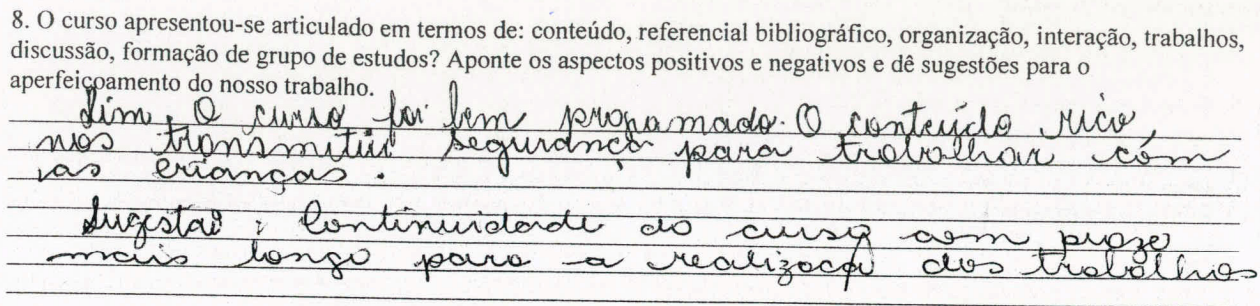

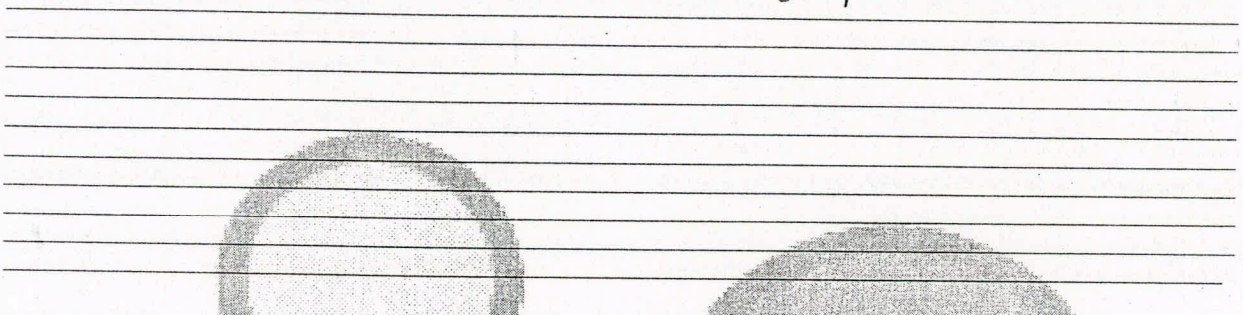

As questões 9 e 10 serão respondidas somente pelos Coordenadores de Grupo de Estudos:

9. Como você avalia seu trabalho junto ao Grupo de Estudos?

(x) Ótimo
( ) Bom
( ) Regular
( ) Fraca
Por que? $\mathcal{L}_{0}$

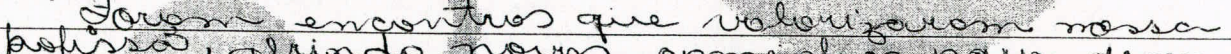
velver, alrindo nourar comintwos palle desen-

10. Como você avalia o uso da Plataforma Teleduc?

(x) Ótimo

( ) Bom

( ) Regular

( ) Fraca

Por que?

Sovem receptivos as aprestàes.

Nome (opcional): Conceícpa Apovecida matins Zrana.

Alfunas ofy de sternbous de 2007

crutubo

Agradecemos a sua colaboração!

Rua 10, 2527 - CEP 13500-230 - RIO CLARO - SP - Brasil - CX. Postal, 178 


\section{unesp}

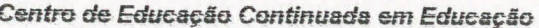

Matematica, Cientifica e Ambiental

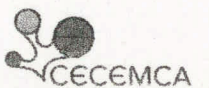

FORMULÁRIO DE AVALIAÇÃo DO CURSO POR PARTE DOS PARTICIPANTES

\section{ÁREAS VERDES}

ALFENAS E REGIÃO

\section{Coordenador de grupo de estudos $\$$}

1. Como você avalia o curso?

() Ótimo

( ) Bom

( ) Regular

( ) Fraco

2. O Curso atendeu às suas cxpcctativas?

( Sim, superou o esperado

( ) Sim, atendeu plenamente

( ) Sim, atendeu parcialmente

( ) Não atcndcu

3. Como você avalia as aulas ministradas? (x) Otimas

( ) Boas

( ) Regulares

( ) Fracas

4. Manifeste sua opinião a respeito do conteúdo. (X) Ótimo

( ) Bom

( ) Regular

( ) Fraco

5. Você recomendaria este curso a outra pessoa? (x) $\operatorname{Sim}$

( ) Não

6. O Tempo de duração dos cursos foi? $(x)$ Satisfatório

( ) Curto

( ) Longo

7. A açầo contribuiu para sua formação? Porque?

$(x) \operatorname{Sim}$

( ) Não

Q

Dorque ao terminar este curso posso dizer are aprevie cas pratica proteger e conscie \&o miso antrente, i meio em que ovidemps

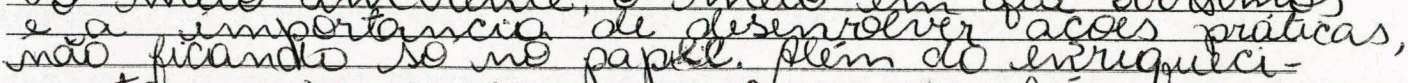
mento na area, foi posbérel ver tanbén crescimento do estuoto em arupo a formacao continuado que mósdo educhacá temos spue Rua 10, 2527 - CEP 13500-230-RIO CLARO - SP-Brasil $\&$ CX. Postal, 178

desenvolvernos constantemente para acompanbar a evolução esrevoluçás. 


\section{unesp 중}

Centro de Educação Continuada em Educacão Matemática, Cientifica e Ambiental

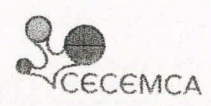

8. O curso apresentou-se articulado em termos de: conteúdo, referencial bibliográfico, organização, interação, trabalhos, discussão, formação de grupo de estudos? Aponte os aspectos positivos e negativos e dê sugestões para o aperfeiçoamento do nosso trabalho.
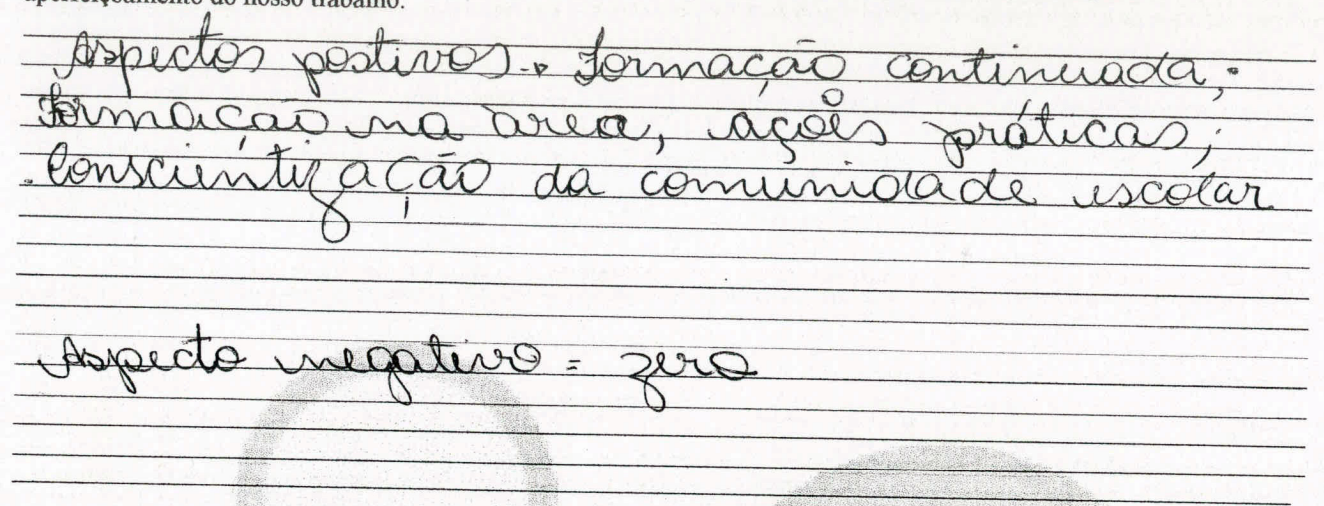

As questões 9 e 10 serão respondidas somente pelos Coordenadores de Grupo de Estudos:

9. Como você avalia seu trabalho junto ao Grupo de Estudos?

$$
\begin{aligned}
& \text { (X) Ótimo } \\
& \text { ( ) Bom } \\
& \text { ( ) Regular } \\
& \text { ( ) Fraca }
\end{aligned}
$$

Por que?

Lorgue munca tire ope refacer wentammo

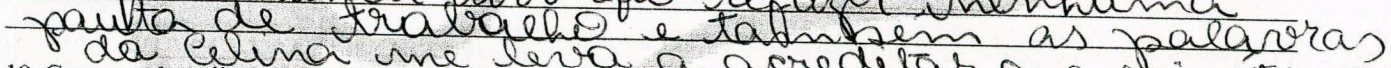
10. Como você avalia o uso da Plataforma Teleduc? (X) Otimo

( ) Bom

( ) Regular

( ) Fraca

Porque?

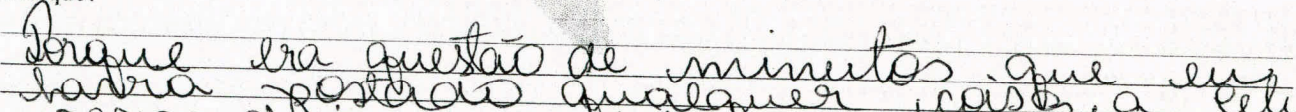

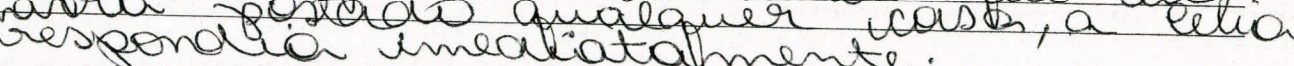

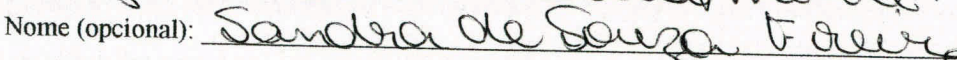

Rio Claro, O6 de Selenvaro de 2007

Agradecemos a sua colaboração! 


\section{unesp}

Centro de Educação Continuada em Educaçảo

Matemática, Cientifica e Ambiental

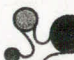

CECEMCA

FORMULÁRIO DE AVALIAÇÃO DO CURSO POR PARTE DOS PARTICIPANTES

\section{ÁREAS VERDES}

ALFENAS E REGIÃO

Coordenador de grupo de estudos $(X)$

Professor Participante ( )

1. Como você avalia o curso?

(X) Ótimo

( ) Bom

( ) Regular

( ) Fraco

2. O Curso atendeu às suas expectativas?

( ) Sim, superou o esperado

(X) Sim, atendeu plenamente

( ) Sim, atendeu parcialmente

( ) Não atendeu

3. Como você avalia as aulas ministradas?

(x) Ótimas

( ) Boas

( ) Regulares

( ) Fracas

4. Manifeste sua opinião a respeito do conteúdo.

(X) Ótimo

( ) Bom

( ) Regular

( ) Fraco

5. Você recomendaria este curso a outra pessoa?

(X) $\mathrm{Sim}$

( ) Não

6. O Tempo de duração dos cursos foi?

( ) Satisfatório

(X) Curto

( ) Longo

7. A ação contribuiu para sua formação? Porque?

(x) $\operatorname{Sim}$

( ) Não

Conbibuir porque vatralizan conhecimentos, que já possura conhecimentos? condir a pesquisas que ampliatam ustes

Rua 10, 2527 - CEP 13500-230 - RIO CLARO - SP - Brasil - CX. Postal, 178 


\section{unesp 흘}

Centro de Educação Continuada em Educação

Matemática, Cientifica e Ambiental

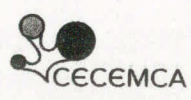

8. O curso apresentou-se articulado em termos de: conteúdo, referencial bibliográfico, organização, interação, trabalhos, discussão, formação de grupo de estudos? Aponte os aspectos positivos e negativos e dê sugestões para o aperfeiçoamento do nosso trabalho.

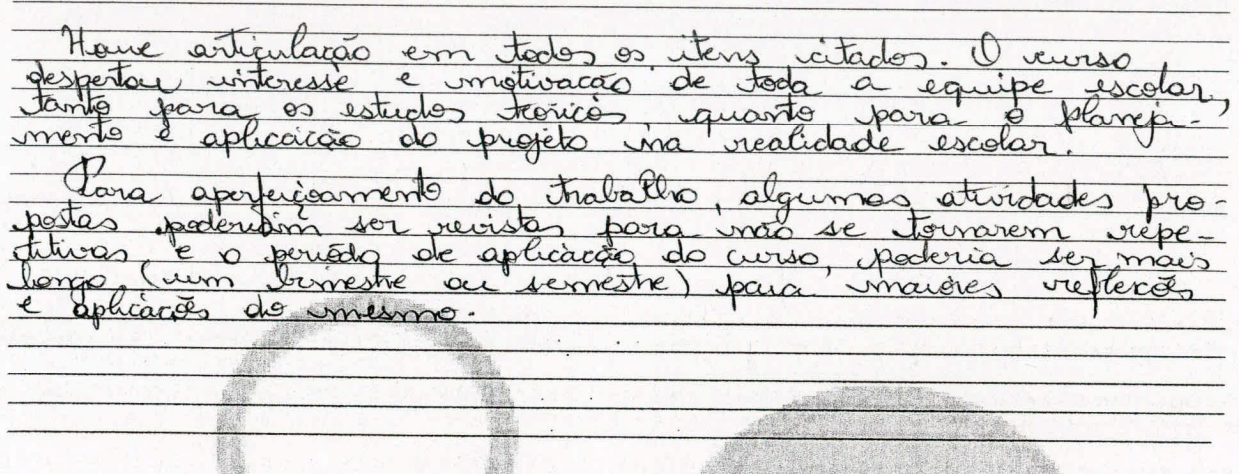

As questões 9 e 10 serão respondidas somente pelos Coordenadores de Grupo de Estudos:

9. Como você avalia seu trabalho junto ao Grupo de Estudos?

$$
\begin{aligned}
& \text { (x) Ótimo } \\
& \text { ( ) Bom } \\
& \text { ( ) Regular } \\
& \text { ( ) Fraca }
\end{aligned}
$$

Por que?

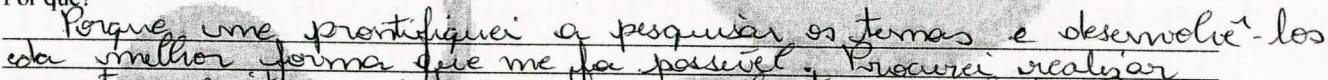

encontios Guatios, interessants, envolventes e sotretudé enri" -

queredores.

10. Como você avalia o uso da Plataforma Teleduc?

( ) Ótimo

(X) Bom

( ) Regular

( ) Fraca

Por que?

Esperava por vmais material de apoio, sobretudo os 1

Nome (opcional): Franciaine Taula Goncalves Téreira

Rio Claro, 18 de setembro de 2007

Agradecemos a sua colaboração! 
$2 \overline{\text { CECEMCA }}$

\section{FORMULÁRIO DE AVALIAÇÃO DO CURSO POR PARTE DOS PARTICIPANTES}

\section{ÁREAS VERDES \\ ALFENAS E REGIÃO}

Coordenador de grupo de estudos (X)

Professor Participante ( )

1. Comov ocê avalia o curso?

() Otimo

() $\mathrm{Bom}$

() Regular

() Fraco

2. Curso atendeu às siabo expectativas ?

( ) Sim, superou o espetado

( ) Sim, atendeu plencicicente

() Sim, atendeu parchalinente

() Não atendeu

3. Como voce avalia a aulas miristradas?

() Otimas

() Boas

() Regulares

() Fracas

4. Manifeste sua opinião a respeito do conteud

() Ótimo

() Bom

() Regular

() Fraco

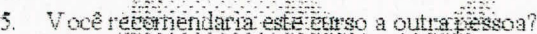

() Sim

() $\mathrm{N}_{\mathrm{a}} \mathrm{O}$

6. Tempo de duração dos curstoxtost

() Satisfatório

() Curto

() Longo

7. A aça contribuiu para sua formação? Porque?

() $\operatorname{sim}$

() Naัo

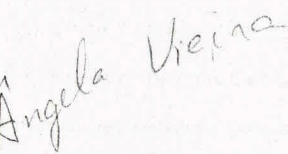


8. curso apresentou-se articulado em termos de: conteudo, referencial bibliográfico, organização, interação, trabalhos, discussào, formaçăo de gorupo de estudos? Aponte os aspectos positivos e negativos e de sugestôs para aperfeicoamento do nosso trabalho.

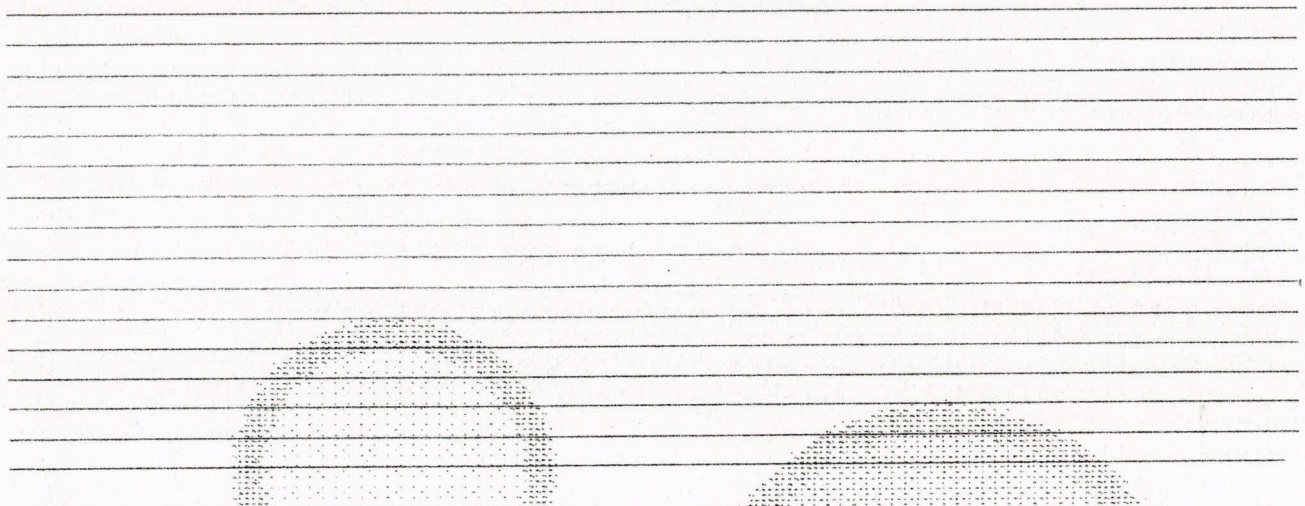

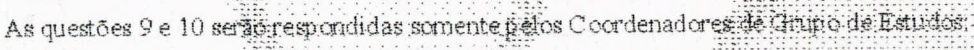

9. Comov oce av alia seti trotaltho juntopo Grupo de Estuder?

() ótimo

$\infty$ Bom

() Regular

() Fraca

Por que?

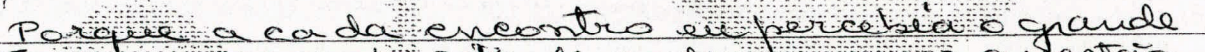

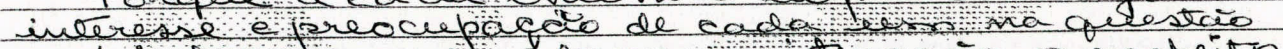

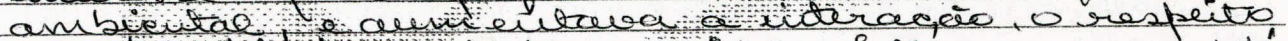
e fraterudade de toda oovipe. Isto era percepté 10. Como vock aratia oude da Plataforma Teleduc?

Xtimo

() Bon

() Regular

() Fraca vel wo comportamen to de todos. fol muito

For que? bom e ungrande aperu. dizado $p$

Sob a incrivel coordenacáo da eeliva, através dos bate-bapos ias tereas piuras, pude eom éxito realizar todos as encointros. Pela plataforma recebia bodos as serpates e teirava as dícillas. obrigada mesmo. Nome (opcional) Angela vivira Ramos.

Rioclaro, de de 2007

Agradecemos a sua colaboraçăo? 


\section{- FORMULÁRIO de AVALIAĊÃO DO CURSO POR PARTE DOS PARTICIPANTES}

\section{ÁREAS VERDES \\ ALFENAS E REGIÃO}

Coordenador de grupo de estudos $\infty$

Professor Participante ( )

1. Como você avalia o curso?

( ) Ótimo

Dom

(1) Regular

( ) Iraco

2. 0 Curso atcndeu às suas expcctativas?

() Sim, superou o csperado

( ) Sim, atcndeu plenamente

D. Sim, atendcu parcialmente

() Não atcndeu

3. Como você avalia as aulas ministradas?

( ) Otimas

Whoas

( ) Regulares

( ) liracas

4. Manifcstc sua opinião a respcito do conteúdo.

( ) Ótimo

Dom

() Regular

( ) Iraco

5. Você recomendaria este curso a outra pessoa?

Q. Sim

( ) Não

6. () Tempo de duração dos cursos foi?

Satisfatório

( ) Curto

( ) Longo

7. A ação contribuiu para sua formação? Porque?

めim

( ) Não

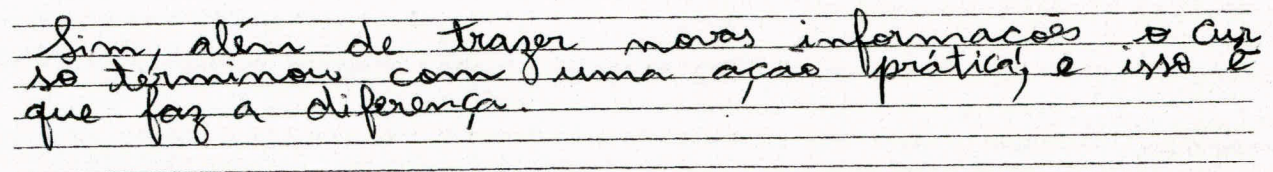




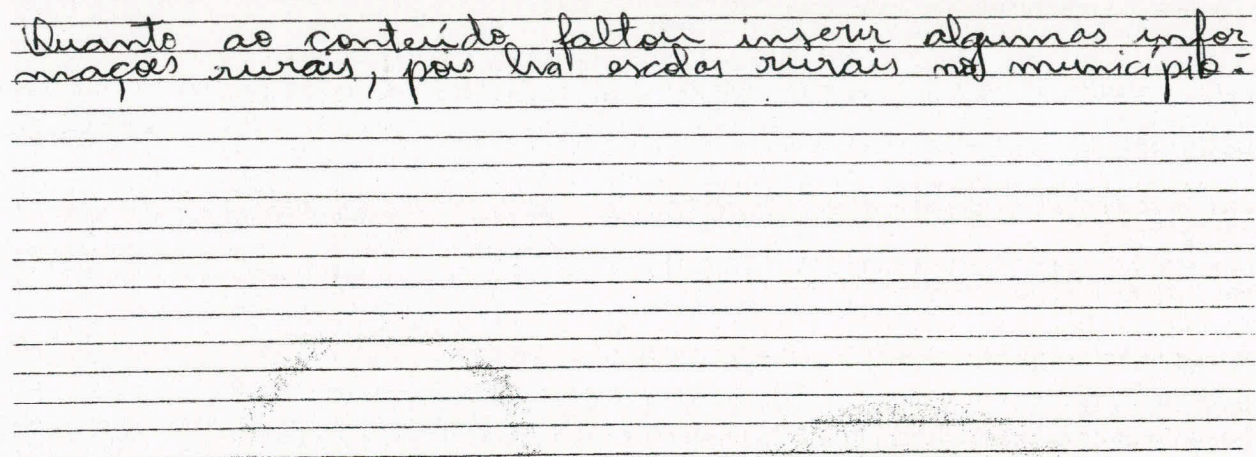

As questões 9 e 10 serão respondidas somente pelos Coordenadores de Grupo de Estudos:

9. Como você avalia seu trabalho junto ao Grupo de Estudos?

( ) Ótimo

Bom

( ) Regular

( ) Fraca

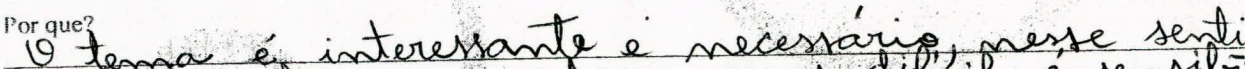
do os educadores cancordam, mas dificil é sensilor lizar para as acoes.

10. Como você avalia o uso da Plataforma Teleduc?

(X́timo

Bom

( ) Regular

( ) Fraca

E'dinga en que quase mäo tenho disponibili

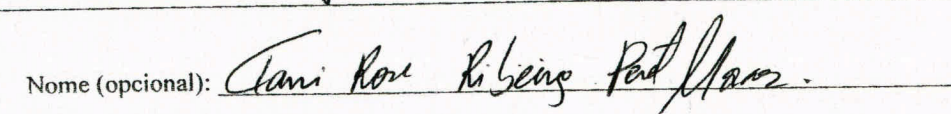

Rio Claro, 01 de setembro de 2007

Agradecemos a sua colaboração! 


\section{unesp \\ Centro de Educação Continuada em Educação Matemática \\ Cientifica e Ambiental

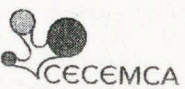

FORMULÁRIO DE AVALIAÇÃO DO CURSO POR PARTE DOS PARTICIPANTES

ÁREAS VERDES

ALFENAS E REGIÃO

Coordenador de grupo de estudos $(X)$

Professor Participante ( )

1. Como você avalia o curso?

( ) Ótimo

(メ) Bom

( .) Regular

( ) Fraco

2. O Curso atendeu às suas expectativas?

(X) Sim, supcrou o esperado

( ) Sim, atendeu plenamente

( ) Sim, atendeu parcialmente

( ) Não atendeu

3. Como você avalia as aulas ministradas?

( ) Ótimas

$(X)$ Boas

Regulares

(.) Fracas

4. Manifeste sua opinião a respeito do conteúdo.

( ) Otimo

(X) Bom

() Regular

( ) Fraco

5. Você recomendaria este curso a outra pessoa?

(メ) $\operatorname{Sim}$

( ) Não

6. O Tempo de duração dos cursos foi?

(メ) Satisfatório

( ) Curto

( ) Longo

7. A ação contribuiu para sua formação? Porque?

( ) $\operatorname{Sim}$

( ) Não

mriquecue os muys combecimento e me despertou mait interresse ecologr

Rua 10, 2527 - CEP 13500-230 - RIO CLARO - SP - Brasil - CX. Postal, 178 


\section{unesp aty \\ Centro de Educaçâo Continuada em Educação Matemática, Cientifica e Ambiental

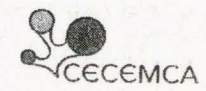

8. O curso apresentou-se articulado em termos de: conteúdo, referencial bibliográfico, organização, interação, trabalhos, discussão, formação de grupo de estudos? Aponte os aspectos positivos e negativos e dê sugestões para o aperfeiçoamento do nosso trabalho.

As questões 9 e 10 serão respondidas somente pelos Coordenadores de Grupo de Estudos:

9. Como você avalia seu trabalho junto ao Grupo de Estudos?

( ) Ótimo

(x) Bom

( ) Regular

( ) Fraca

Por que?

Qive ayida de todos

10. Como você avalia o uso da Plataforma Teleduc?

( ) Ótimo

(X) Bom

( ) Regular

( ) Fraca

Por que?

Nome (opcional):

Rio Claro, de de 2007

Agradecemos a sua colaboração!

Rua 10, 2527 - CEP 13500-230 - RIO CLARO - SP - Brasil - CX. Postal, 178 


\section{unesp \\ Centro de Educação Continuada em Educação Matemática, Cientifica e Ambiental

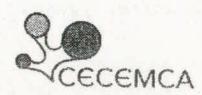

8. O curso apresentou-se articulado em termos de: conteúdo, referencial bibliográfico, organização, interação, trabalhos, discussão, formação de grupo de estudos? Aponte os aspectos positivos e negativos e dê sugestões para o aperfeiçoamento, do nosso trabalho,

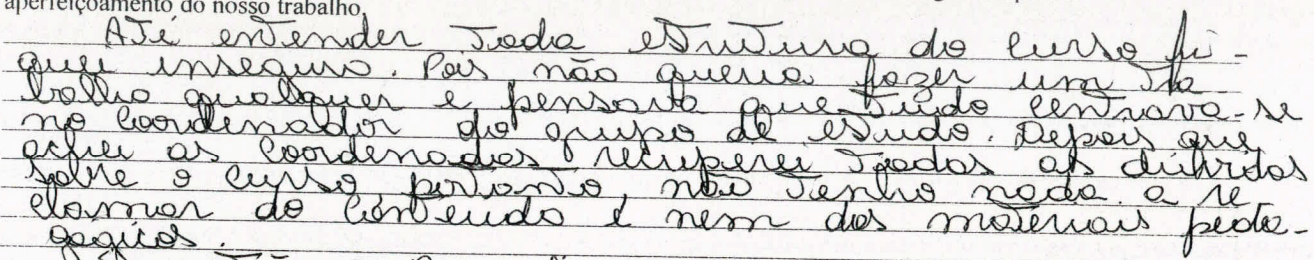

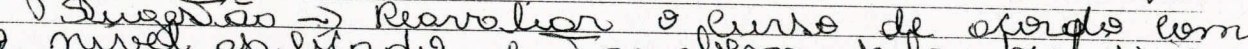

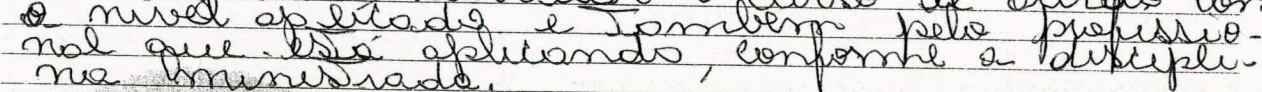

nue mumusradd.

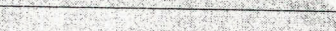

As questões 9 e 10 serão respondidas somente pelos Coordenadores de Grupo de Estudos:

9. Como você avalia seu trabalho junto ao Grupo de Estudos?

( ) Ótimo

(x) Bom

( ) Regular

( ) Fraca

Por que?

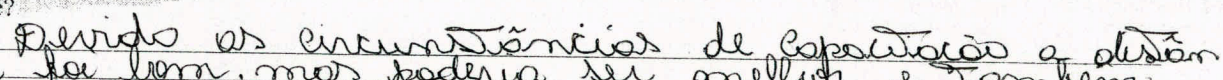

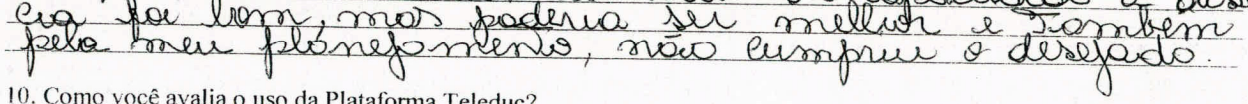

10. Como você avalia o uso da Plataforma Teleduc?

$(\alpha)$ Otimo

( ) Bom

( ) Regular

( ) Fraca

Por que?

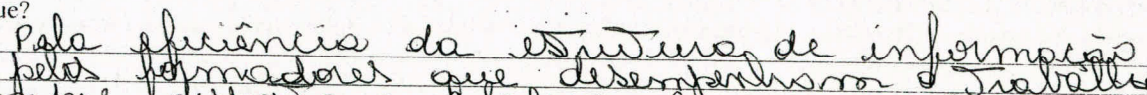

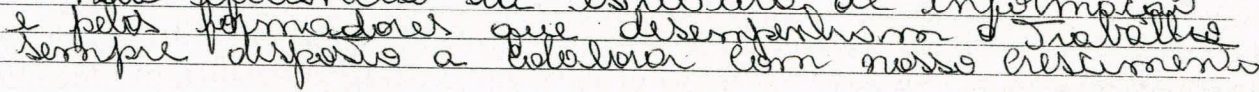
Nome (opcional): Jose conbs - tutor

Rio Claro, 10 de Qivele de 2007

ols. As perguntas anteriores, nōo respondi,

saos, penguntas do nosso catidiono. OK! 


\section{unesp}

Centro de Educação Continuada em Educação

Matemática, Científica e Ambiental

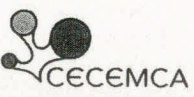

FORMULÁRIO DE AVALIAÇÃO DO CURSO POR PARTE DOS PARTICIPANTES

ÁREAS VERDES

ALFENAS E REGIÃO

Coordenador de grupo de estudos $(X)$

1. Como você avalia o curso?

Professor Participante ( )

(X) Ótimo

( ) Bom

( ) Regular

( ) Fraco

2. O Curso atendeu às suas expectativas?

( ) Sim, superou o esperado

(X) Sim, atendeu plenamente

( ) Sim, atendeu parcialmente

( ) Não atendeu

3. Como você avalia as aulas ministradas?

( ) Ótimas

(X) Boas

( ) Regulares

( ) Fracas

4. Manifeste sua opinião a respeito do conteúdo.

(X) Ótimo

( ) Bom

( ) Regular

( ) Fraco

5. Você recomendaria este curso a outra pessoa?

(X) $\operatorname{Sim}$

( ) Não

6. O Tempo de duração dos cursos foi?

(X) Satisfatório

( ) Curto

( ) Longo

7. A ação contribuiu para sua formação? Porque?

(X) $\operatorname{Sim}$

( ) Não

Porque zude aprender mito, peh tato de estair ministrantw as avlas, pava, os outros brotessoves, as mesmo tempo em que alprendio e entudbuda. 


\section{unesp}

Centro de Educação Continuada em Educação

Matemática, Cientifica e Ambiental

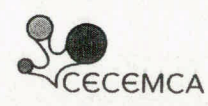

8. O curso apresentou-se articulado em termos de: conteúdo, referencial bibliográfico, organização, interação, trabalhos, discussão, formação de grupo de estudos? Aponte os aspectos positivos e negativos e dê sugestões para o aperfeiçoamento do nosso trabalho.

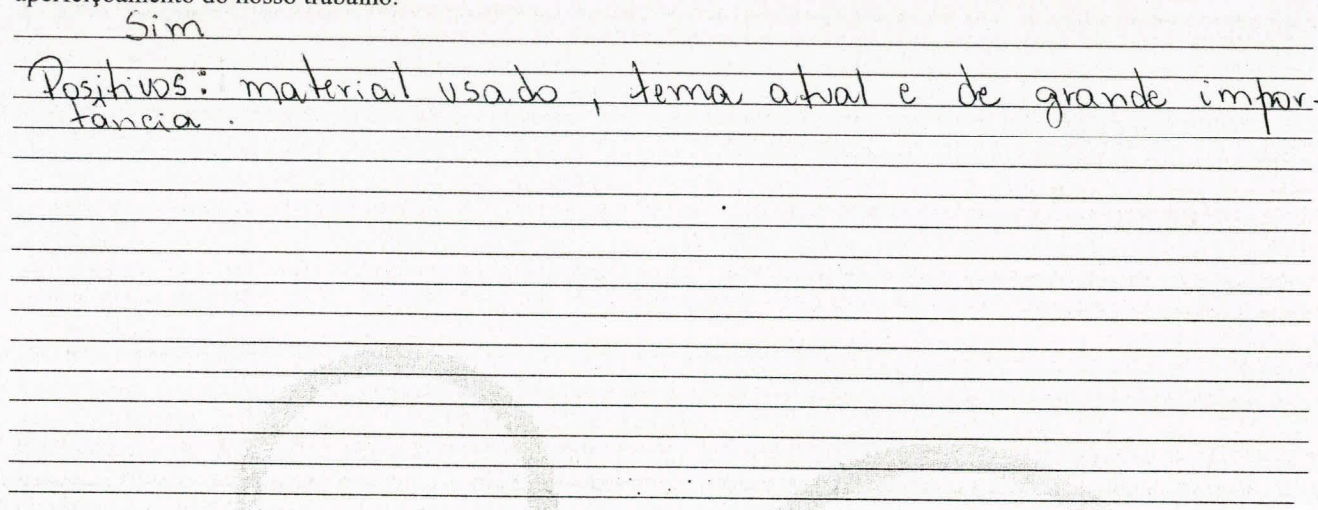

As questões 9 e 10 serão respondidas somente pelos Coordenadores de Grupo de Estudos:

9. Como você avalia seu trabalho junto ao Grupo de Estudos?
( ) Ótimo
(X) Bom
( ) Regular
( ) Fraca

Por que?

10. Como você avalia o uso da Plataforma Teleduc?

( ) Ótimo

(X) Bom

() Regular

( ) Fraca

Por que?

Nome (opcional): Pelmo Perevra

Rio Claro, de de 2007

Agradecemos a sua colaboração!

Rua 10, 2527 - CEP 13500-230 - RIO CLARO - SP - Brasil - CX. Postal, 178 


\section{unesp \\ Centro de Educação Continuada em Educação Matemática, Cientifica e Ambiental

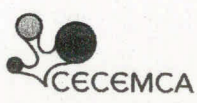

\section{FORMULÁRIO DE AVALIAÇÃO DO CURSO POR PARTE DOS PARTICIPANTES \\ ÁREAS VERDES \\ ALFENAS E REGIÃO}

Coordenador de grupo de estudos $(X)$

Professor Participante ( )

1. Como você avalia o curso?

(X) Ótimo

( ) Bom

( ) Regular

( ) Fraco

2. O Curso atendeu às suas expectativas?

(丈) Sim, superou o esperado

( ) Sim, atendeu plenamente

( ) Sim, atendeu parcialmente

( ) Não atendeu

3. Como você avalia as aulas ministradas?

( ) Ótimas

(X) Boas

( ) Regulares

( ) Fracas

4. Manifeste sua opinião a respeito do conteúdo.

(X) Ótimo

( ) Bom

( ) Regular

( ) Fraco

5. Você recomendaria este curso a outra pessoa?

(X) Sim

( ) Não

6. O Tempo de duração dos cursos foi?

(X) Satisfatório

( ) Curto

( ) Longo

7. A ação contribuiu para sua formação? Porque?

(X) Sim

( ) Não

Este curso contrilri muito jeara minha formacáo de la ucadora, rois Aou graduada em liemcias Bülógicas e Especialista en Eoucacaro ombiental. Curto muito ista ared loco este curso me ajidou muito na local de trabalho. 


\section{unesp * \\ Centro de Educação Continuada em Educação Matemática, Cientifica e Ambiental

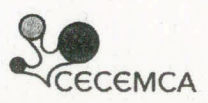

8. O curso apresentou-se articulado em termos de: conteúdo, referencial bibliográfico, organização, interação, trabalhos, discussão, formação de grupo de estudos? Aponte os aspectos positivos e negativos e dê sugestões para o aperfeiçoamento do nosso trabalho.

- curso loi muito oneroso para os professores con muitas aturdades escritas, porque a maioria traballa im actras escolas i mavo disper de

Was, os sus djetivos sao clares e importantes, pois através acos exemplos da comundade descolar, os alunos suao multiplicadores nos sus lares. Ha muitos casos em nossa escola, en que as familias estao muito desestruturadas lo dinico amparo é a escola.

Por ios, nos edveadores, por mais difécil que seja a realidade temos que litar para a melhoria da qualidade de irda atraves do denenoter sfento sustentavel. Portanto, prógetos cono este devern ser elaborados e aperflicoados poorque

Winera suglstaio \& que dinninua o número de atividades, wnas $\theta$ conteú do, a lingudagm do livio sac exculentes e devern continuar neste nuel porque nem todos os professores participantes sốo da área específica cono liencias e Biologia. Nepróxuno curso, as listas de presença devem ser dadas antecipadc. As questões 9 e 10 serão respondidas somente pelos Coordenadores de Grupo de Estudos:

9. Como você avalia seu trabalho junto ao Grupo de Estudos?

( ) Ótimo

(X) Bom

( ) Regular

( ) Fraca

Por que?

Creio que fiz um bom traballro, mas aci que houve fallhas, afinal mato
sou pirfeith?

10. Como você avalia o uso da Plataforma Teleduc?

(X) Ótimo

( ) Bom

( ) Regular

( ) Fraca

Por que?

Por

Porque é una plataforma perática e dinámica. Tenos una excelente orientadora: paciente e muito atenciosa

Nome (opcional): II arinalva silva Wiranda

Rio Claro, 29 de agpeste de 2007

Agradecemos a sua colaboração!

Rua 10, 2527 - CEP 13500-230 - RIO CLARO - SP - Brasil - CX. Postal, 178 


\section{unesp \\ Centro de Educação Continuada em Educação \\ Matemática, Científica e Ambiental

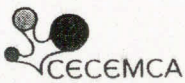

FORMULÁRIO DE AVALIAÇÃO DO CURSO POR PARTE DOS PARTICIPANTES

ÁREAS VERDES

ALFENAS E REGIÃO

Coordenador de grupo de estudos $(x)$

Professor Participante ( )

1. Como você avalia o curso?

(x) Ótimo

( ) Bom

( ) Regular

( ) Fraco

2. Curso atendeu às suas expectativas?

(x) Sim, superou o esperado

( ) Sim, atendeu plenamente

( ) Sim, atendeu parcialmente

( ) Não atendeu

3. Como você avalia as aulas ministradas?

( ) Ótimas

(x) Boas

( ) Regulares

( ) Fracas

4. Manifeste sua opinião a respeito do conteúdo

(x) Ótimo

( ) Bom

( ) Regular

( ) Fraco

5. Você recomendaria este curso a outra pessoa?

(x) $\operatorname{Sim}$

( ) Não

6. O Tempo de duração dos cursos foi?

(x) Satisfatório

( ) Curto

( ) Longo

7. A ação contribuiu para sua formação? Porque?

(x) $\mathrm{Sim}$

( ) Não

loir tive a aratunidade de acrescertor algo a mais em mens conbeimenton, glem de traballar e aplicar eme nalo de aula

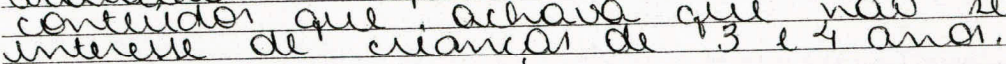


O curso apresentou-se articulado em termos de: conteúdo, referencial bibliográfico, organização, interação, trabalhos, discussão, formação de grupo de estudos? Aponte os aspectos positivos e negativos e dê sugestões para o aperfeiçoamento do nosso trabalho.

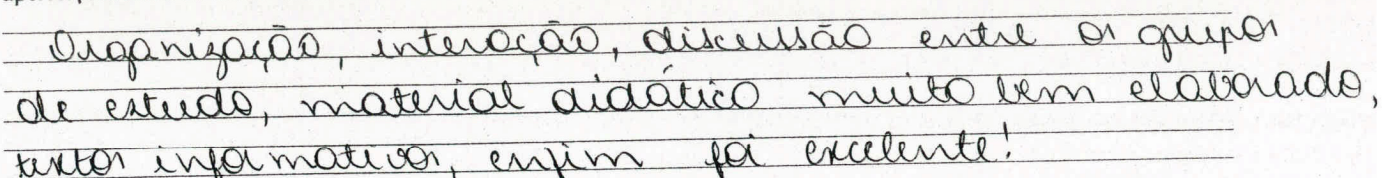
turtor infor matevor, empim for excelente.

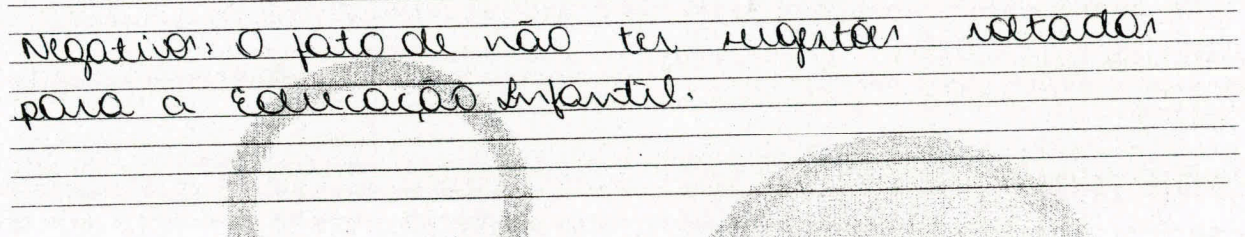

As questões 9 e 10 serão respondidas somente pelos Coordenadores de Grupo de Estudos:

9. Como você avalia seu trabalho junto ao Grupo de Estudos?
( ) Ótimo
(x) Bom
( ) Regular
( ) Fraca

Porque? Houve grande participacāo e interesse Nor parte do grupo.

10. Como você avalia o uso da Plataforma Teleduc?

(x) Ótimo

( ) Bom

( ) Regular

( ) Fraca

Por que?

Dair tudo que nuisávamon remprestova

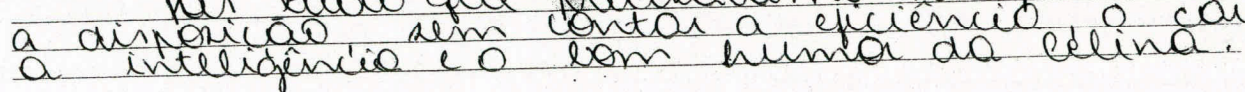
Nome (opcional): Juceli Graziela Nartins.

Rio Claro, de de 2007

\section{Agradecemos a sua colaboração!}




\section{unesp}

Centro de Educação Continuada em Educação

Matemática, Cientifica o Ambiental

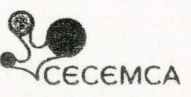

- FORMULÁRIO DE AVALIAÇÃọ dO CURSO POR PARTE DOS PARTICIPANTES

ÁREAS VERDES

ALFENAS E REGIÃO

Coordenador de grupo de estudos $(x)$

Professor Participante ( )

I. Como você avalia o curso?

() Ótimo

( ) Bom

( ) Regular

( ) Iraco

2. O Curso atendeu às suas expectativas?

( ) Sim, superou o csperado

$($ Sim, atendeu plenamente

( ) Sim, atendeu parcialmente

( ) Não atcndeu

3. Como você avalia as aulas ministradas?

(メótimas

( ) Boas

( ) Regulares

() Fracas

4. Manifcste sua opinião a respcito do conteúdo.

( ) Ólimo

( $)$ Bom

( ) Regular

( ) Fraco

5. Você recomendaria estécurso a outra pessoa?

$\infty$ Sim

( ) Não

6. O Tempo de duração dos cursos foi?

(メ) Satisfatório

( ) Curto

( ) Longo

7. $\wedge$ ação contribuiu para sua formação? Porque?

$\bowtie \operatorname{sim}$

( INo ser un curso aleerto tivemos a coportunidado de trocarmos muitas informacoes e experiancias

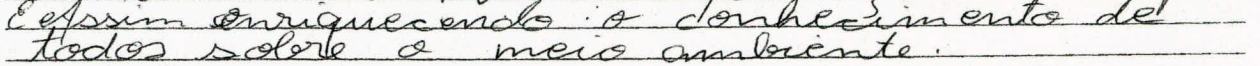


8. 3) curso apresentou-se articulado em termos de: conteúdo, referencial bibliográfico, organização, interação, trabalhos, discussão, formação de grupo de estudos? Aponte os aspectos positivos e negativos e dê sugestôes para o aperfeiçoamento do nosso trabalho.

As questões 9 e 10 serão respondidas somente pelos Coordenadores de Grupo de Estudos:

9. Como você avalia seu trabalbo junto ao Grupo de Estudos?

$$
\begin{aligned}
& \text { ( ) Ótimo } \\
& \text { ( ) Bom } \\
& \text { ( ) Regular } \\
& \text { ( ) Fraca }
\end{aligned}
$$

'orque? foaltiamos de una manevia paragerosa onde todos deram a sua contrileticós 10. Como você avalia o uso da Plataforma Teleduc?

(x) Ótimo

() Bom

() Regular

( ) Fraca

Por que?

Otime, porque esclariose plenamente as, nossas duñdars le vern por ane a nosse venyo e duponctividade e culto

Nome (opcional): Elande fele Pereria

ALFENAS

Pioetere, de

$$
\text { temboro de } 2007
$$

Agradecemos a sua colaboração! 